\title{
Commentary on Heracleopolis Magna from the theological perspective (I): the image of the local lakes in the vignette of chapter 17 of the Book of the dead
}

\author{
Lucía Elena DÍAZ-IGLESIAS LLANOS
}

\begin{abstract}
The process of endowing a symbolic meaning to the most prominent marks in the landscape can be illustrated by a distinctive feature of Heracleopolis Magna: the sacred lake of the temple of Heryshef. Its dominant position in the city, its relationship with the local temple and its importance in the royal sphere led to its projection from this world to the Beyond. The analysis of funerary texts and vignettes from the First Intermediate Period onwards show that the lakes were considered as a significant place for the purification and rebirth of the deceased.

El proceso de dotación de un significado simbólico a los rasgos más prominentes del paisaje puede ser ilustrado por medio de una característica distintiva de Heracleópolis Magna: el lago sagrado del templo de Heryshef. Su posición dominante en la ciudad, su relación con el templo local y su importancia en la esfera regia condujo a su proyección desde este mundo al Más Allá. El análisis de textos y viñetas de naturaleza funeraria fechados desde el Primer Periodo Intermedio en adelante muestra que los lagos fueron considerados como un lugar significativo para la purificación y renacimiento del difunto.
\end{abstract}

KEY WoRDs: Heracleopolitan Lakes; CT 335; chapter 17 of the BD; vignette; fecundity figures; feathered eye; mytheme; purification; rebirth.

$\mathrm{T}$ he Egyptians conceived a symbolic dimension of the landscape, as a space which was experienced, thought about, rendered meaningful, and shaped both by beliefs and language. This conception is part of an intellectual process and effort aimed at ordering and recreating the immediate surroundings, as well as at recognizing the significant elements on a cosmic, mythological, funerary level, in the most significant landscape features.

In order to illustrate this process we will focus on the natural and cultually- distinctive feature of the city of Heracleopolis Magna: the sacred lake of the temple of the god Heryshef. Based on sources from the First Intermediate Period (FIP)/ Middle Kingdom (MK) onward found in funerary contexts, i.e. devised to ensure the access of the deceased to the Hereafter $^{1}$, we will show how the symbol of the lake is projected to the realm of the gods and the dead and thus inserted in a "mythical topography". These texts have preserved the names given to the Heracleopolitan pools, their pictorial representation and mythological role in the other world. In this article attention will be

* Becaria de investigación del Programa Nacional de Formación de Profesorado Universitario (FPU), referencia AP2005-0388. I am grateful to Dr. I. Munro and the Totenbuch-Projekt team for their kindness and willingness to let me pursue my research at the archive and accomplish the catalogue of documents (Appendix I) on which this article is based.

1. Many texts (magical compositions against the bite of poisonous animals, expressed wishes to live 110 years ...) had some purpose during life before being used as funerary spells. Regardless of their origin, our interest is centred on the meaning that the spells in the corpus of Coffin Texts (from now on CT) acquire in their new context. 
paid to the images of the lakes included in the vignette in chapter 17 of the Book of the Dead (BD). It is our intention to complement this analytical work with two further articles to be published in subsequent issues of this journal. The first of these will combine the conclusions of the iconographic review of the symbolism of the scenes, with the content of the funerary texts. The second will deal with the possible pictorial and contextual relationship between the image of the lakes in chapter 17 of the BD with one element included among the scenes of chapter 125 of the BD.

\section{The Heracleopolitan Lakes in Funerary LiTERATURE}

Before undertaking the formal examination of the vignettes it is necessary to clarify what is known about the Heracleopolitan lake in the light of the archaeological and written records. The origin of the pool lies probably in the natural configuration of the water table, which must have been very close to the surface in this area of Middle Egypt, near the Fayumitic depression. Even though the temenos of Heryshef's main religious complex has not been definitively determined ${ }^{2}$, it seems that the lake was held to be of ritual and mythological significance since the creation of the temple. In the absence of geomagnetic and sedimentological surveys of the site, we can only assume that the lake could have been located in one of the depressions lying between the hills close to the temple ${ }^{3}$. In recent pictures of the sanctuary of the ram-god, the ruins of the building are partially sunk under the water (fig. 1) $)^{4}$. This fact may be related to the general rise of the water table since the construction of the dam in Aswan. Instead, it could indicate that in ancient times the level of the water table was closer to the surface in certain areas of the city and flowed naturally.

Under the name $\check{s}$, the lake ${ }^{5}$ is mentioned in documents that range from Den's reign in the Palermo Stone ${ }^{6}$ (fig. 2) to the 30th Dynasty in

2. The "Roman wall" (so-called by Petrie and considered by Padró as the MK southern wall of the city) could in fact be either the temenos of Heryshef's first temple or a reconstruction of this same structure in the late New Kingdom (Pérez Die, 2005b: 254).

3. Mokhtar suggests that the lake occupied the space to the north of Kôm el-Aqarib and to the south of the Temple of Heryshef, a small plain where neither archaeological remains nor any evidence of the sebakhin's works have been found (1983: 90).

4. Mokhtar, 1983: pl. IIIA and B; Padró, 1999: 333, pl. III (upper); Pérez Die; Vernus, 1992: 146, pl. IV a.

5. According to several interpretations $\breve{s}$ can refer to: 1: water extensions such as natural or artificial lakes associated with temples, pools excavated in the middle of gardens, the sea or a stream of water -Wb. IV, 397 , 1- 398, 5-6; 2: a region or territory, described by different authors as: "a district" (Geßler-Löhr, 1983: 127); "place of production or where an activity (whichever) is carried out, associated with a palace or funerary complex without being in its vicinity" (Posener-Krieger, 1976: 578-579 y n. 5); district and when associated with $p r$ - 3 a royal district in which the funerary complex and its outbuildings (temple, pyramid city) or the palace are located (Stadelman, 1981: 158-160, 162); "area, piece of land, plot for production of anthropic origin to support the royal funerary temple, the palace or certain private states" (Diego Espinel, 2006: 62-63).

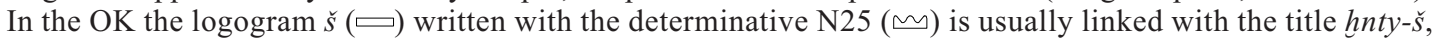
created in the 5th Dynasty or earlier according to Baud $(1995: 14,31)$ to supervise these areas of production (see also Stadelmann (1981: 156) but $c f r$. Roth (1991), who argues they are linked with the personal service to the king). No such a determinative appears in the Palermo Stone in our case of study but it is recorded in this and other documents beside the sign $\check{s}$ when this place is planned or inaugurated (Stadelman, 1981: 159, 162, Abb. 2-3).

6. $\varsigma^{\ulcorner} n n-n s w \check{s} h w t-n t r h r y-\check{s}=f:$ year $\mathrm{X}+9$ of Den (PS r.III.9), according to the transcription of Wilkinson, 2000: 115. We follow the widely accepted translation, though Godron suggests: "build the temple of Heryshef, of the lake of Heracleopolis" (1990: $§ 540-567)$. His hypothesis entails changing the reading order of the signs, and we prefer to translate ${ }^{c} h^{\mathrm{C}}$ as a ceremonial visit to or a royal stay in a structure, especially a religious one. This opinion is shared by Schäfer, 1902: 20; Bonnet, $R \ddot{A} R G$ : 228; Kees, 1930: 71; Breasted, ARE II, 61, n. b; Wilkisnon, 2000: 115-116. Another line of interpretation is opened by Geßler-Löhr, 1983: 130-131, who translates $\check{s}$ as area or district and thus the entry as: "visit to the district of the temple...". 


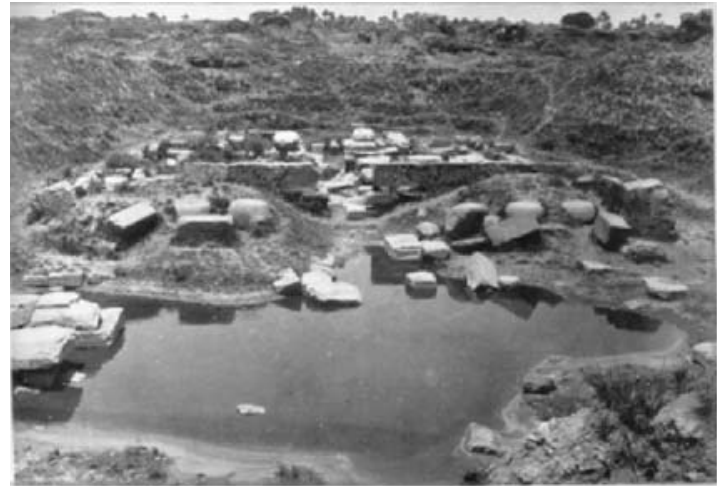

Figure 1: Remains of the temple of Heryshef, partially covered by a layer of water; from Mokhtar 1983: pl. III B.

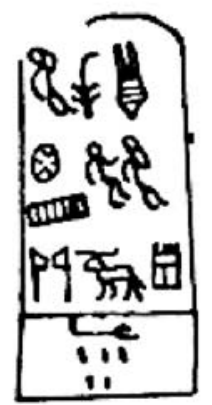

Figure 2: Year $X+10$ of Den's reign in Palermo Stone; from Mokhtar 1983: fig. 33. the statue of $\mathrm{Hor}^{7}$. In the section devoted to the annals of Den there is a record of the visit of this king to the temple $\mathrm{pool}^{8}$. On the one hand it recalls an act of royal patronage, probably revealing that the lake had some religious or ideological function in the royal sphere, the nature of which can-not be ascertained ${ }^{9}$, and on the other, the consolidation of the cult of the ram god in the city. The tutelar deity of the temple, in his name of Heryshef or "the one that is over his lake", seems to have been closely linked to this body of water ${ }^{10}$. The pool thus probably existed before the formation of the god's name, and his figure would therefore reproduce/reflect the self-creation mytheme, i.e. of the god that emerges from the primeval water chaos.

It seems that at least since the FIP, when Heracleopolis was raised in status to be the capital (in a more nominal than real way) of the kingdom, the lake became an axis of the local theological perspective. The mythological imagery devised around it was passed down in some of the most popular passages of the funerary literature composed during the FIP / MK -CT 335- and re-edited with changes from the New Kingdom (NK) on -BD 17-.

7. Statue of Hor -Louvre A 88- published by Vercoutter, 1950 (for $\check{s} m \jmath^{\circledR C}$ or Pure Lake: $\S 3$ and n. s). A contemporary statue from Dyed Hor mentiones a lake in Heracleopolis Magna where Osiris was buried, combining in this reference the landscape of cult and of myth, whereby there existed a tomb of this god in the vicinity of the city (Daressy, 1919: 123). The Ramesside pWilbour records the name $m r-m 3^{c}$ (B. 22, 27 (33)), the spelling and location of which shows similarities to the lake mentioned in Louvre A88.

8. We will not tackle the problem of dating the main religious structure in the capital. At the core of it lies the discontinuity between archaeological sources, which do not support a date before the MK, and written and iconographic ones, that point to the existence of a chapel consecrated to the ram god earlier. Among the latter we highlight: 1) an ivory etiquette in Den's tomb? -Petrie, 1900-1901: II, 25, pl. VII, ${ }^{\circ}$ 8-9-; 2) the inscription $m r y$ hnty $=f$, hwt-ntr $b 3(?){ }^{`} n h(w) d t$ in the diorite statue of Menkaure JE $28578=$ CGC 42 -Borchardt, 1911: 39 , $\mathrm{n}^{\circ}$ 42; PM III': 842-843-; 3) references to the local temple in a passage of the Eloquent Peasant -B1 225-226 in Parkinson's edition (1991) and B1 194-196 in that of Lefebure (2003)-; 4) a spell of CT -V, 257 a-i [420], recorded in coffins B1L, B1Y y S2C-.

9. It has been suggested that the lake was given to the city as a present by this king (Vernus, 1967: 166) or was consecrated in the 1st Dynasty (Gomàa, 1977a: L̈̈ II, 1125, Anm. 9; id., 1986: 361 and n. 5). Instead, it could have simply been the object of a royal visit in consideration of its prestige, purifying capacity, symbolic meaning..., important enough to be recorded in a document of ideological purpose which was displayed in a cultual context.

10. Mokhtar, 1983: 146-147 (b). The Ramesside interpretations of his name produce the versions "ram's face", "the one with a magnific / imposing apperance". The element $\check{s}$ in the god's name has been identified with the Lake Moeris in the Fayum (Naville, 1894: 7; Hassan, 1928: 101; Weill, 1936: 141; Zibelius, 1978: 237, Anm. 1345) or with the pool in the temple of this god at Heracleopolis Magna (Wainwright, 1934: 143; Kees, 1930: 71; Bonnet, $R \ddot{A R} R$ : 228; Altenmüller, 1977 a: $L \ddot{A}$ II, 1015-1018), an opinion that we share. $C f$. Geßler-Löhr, 1983: 132, who translates the name as "the one that is over his district" (see n. 6 above) 
Spell CT $335^{11}$ is widely used, especially from the reign of Amenemhat II onwards, and is usually written inside the lid, a distinctive position which reflects its association with the sky. This fact may be explained by the wish to connect location and subject matter, since the spell is notable for its solar references and allusions to a heavenly journey, which is equated with the rebirth of the dead. The mythical argument uniting all the episodes in this piece of funerary literature is as follows: a young and active god (the deceased, who assumes the identity of several deities) engages in a trip to a chapel located in the eastern horizon, in order to accomplish the rites of reanimation and protection of the body of his dead father (Osiris) before dawn ${ }^{12}$. During this journey he passes through Heracleopolis Magna, where he states:

$$
\underline{d} r(w) i w=i, \underline{h} s r(w) n i t=i, \operatorname{shry} i s f t i r(y) t=i .
$$
$w^{\complement} b \sim n=i m$ sšwy ip w wrwy 3 wy ntyw mnn$n s w, s w^{\top} b$ Sbt rhyt n ntr $p w{ }^{\top}$ nty im $=$ s. ptr

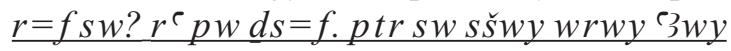

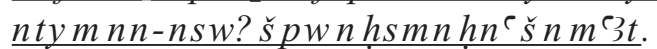

My wrongdoing has been done away with, my evil has been dispelled ${ }^{13}$, the falseness that adhered to me has been removed ${ }^{14}$. I have bathed / purified in those two great and stately lakes which are in Heracleopolis Magna, in which offerings of the rekhyt have been cleansed, for this great god who is within (=the city). Who is he? He is Re himself. What are those two great and stately lakes that are in Heracleopolis Magna? They are the Lake of Natron and the Lake of Maat ${ }^{15}$.

The spell recounts the function for which the lakes are fitted in the hereafter, the destruction of the wrongdoings of the late Osiris-NN by means of water, and specifically links this purification with his rebirth. Chapter 17 of the BD passes on CT 335 to the NK and Late Period (LP), albeit introducing some variations ${ }^{16}$ :

$\underline{d} r(w) i w=i, h s r w \underline{d} w t=i . p \underline{w-t r} r=f s t$ ? $\underline{s}\left\ulcorner d=t w h p 3 p w n(m n-h p r-r)^{\top}\right) m 3^{\complement}-h r w$. shrw $\underline{d} w t n b t \operatorname{ir}(y) t=f . p \underline{w-t r} r=f s t$ ? $\underline{w^{c} b}=t w=i p w h r w m s=t(w)=i . w^{c} b=i \mathrm{~m}$ š̌wy wrwy $3 w y$ nty $m n n-n s w, h r w ~ 3 b t$

11. The passage mentioning the lakes is CT IV, 206/207 b- 216/227 a [335] = Urk. V, 21-30, Abschnitte 10-14. Analysis and translations of the spell in: Heerma Van Voss, 1963; Rößler-Köhler, 1979; Faulkner, 1994: I, 263; Barguet, 1986: 565-566; Shalomi-Hen, 2000: 3-23, includes an up-to-date introduction to the sources, issues and means of transmission of the spell.

12. The mytheme has been thoroughly analyzed by Willems, who points out that the subject matter does not only play an important role in the Osiris-Horus constellation. It surfaces in the Book of Shu, where the main characters are Shu (in the role of young god and son) and Atum (as dead father) -1996 c: 270-324; 1997: 360-361- and in those passages that describe the embrace of Re (active deity) and Osiris (deceased god) -specially CT IV, 276/277 a-280/281 a [335]-. According to Allen (1988: 31), the main topic is the equation established between the transit of the deceased from tomb to daylight and of the sun from dusk to dawn. As regards Shalomi-Hen (2000: 13), the purpose of the text is explicit in its own title: allow the dead a free exit from and entrance to the Reign of the Dead.

13. Coffin $\mathrm{BH} 1 \mathrm{Br}$ inserts a gloss which links the removal of evil with rebirth: $s y$ ty $p w$ ? $\breve{s} d=t w h p 3=f p w$. prt $m$ hrw. "What does it mean? It means that his navel string has been cut. Going out into the day" -CT IV, $209 \mathrm{e}-\mathrm{g}$ [335]-.

14. Again $\mathrm{BH} 1 \mathrm{Br}$ interpolates a gloss that connects the destruction of wrongdoings with purification of the newborn baby: sy ty $p w$ ? $w^{c} b=f p w m=h t m s=t w=f$. "What does it mean? It means that he cleanses himself, after he was born"-CT IV, $211 \mathrm{c}-\mathrm{d}[335]-$.

15. For the wide range of variants of this passage, which record the name of the lakes see n. 28 and 36.

16. We follow the version in CG 40001, JE 2623 (mummy linen of Tuthmosis III) published by Munro, 1994: document L.TIII: 41, 45, Taf. 32-35. Other variants of the text in Naville, Tb., Taf. XXIII, 1. 19-23, based on pLondon BM 9900 (18th Dynasty); Lepsius, Tb., Taf. VII, 1. 14-18, based on pTurin 1791 (Ptolemaic Period). To the catalogue of sources of chapter 17 of the BD gathered by Rößler-Köhler, 1979: 1-9, must be added coffin BM EA 29997 belonging to the prince Hunefer (Parkinson; Quirke, 1992). It is the earliest document to record this chapter, together with the sarcophagus of queen Montuhotep, today lost, but known through the facsimile copy of Wilkinson -BMEA 10533, published by Geisen, 2004-. For the most recent synoptic edition of this chapter compiled after NK sources see Lapp, 2006. Bibliographic references to the chapter in Gülden; Munro, 1998: 84-89, and translations in Allen, 1974: 28, 17 a § S 8-9; Rößler-Köhler, 1979: 216-217; Barguet, 2000: 58-59. 
rhyt $n$ ntr pwy 3 nty im $=s . p w-t r r=f s w ?$ hhrn $n w^{\top}, w 3 d-w r r n n k y, \check{s} p w h s m n h n^{\ulcorner} \check{s}$ $n$ m 3. kydd: šsm hhrn $n w^{c}, w 3 d$-wr rn nky. ky: wtwt /mtwt hh rn n we, w3d-wr rn nky. irgrtntrpwy 3 nty im $=s, r^{c} p w d s=f$.

My wrongdoing has been removed, my evil has been done away with. What is that? It means that the navel string has been cut in the birth of Men-Kheper-Re, true of voice. All evil that adhered to me has been cast away. What is that? It means that I have been cleansed / purified on the day I was born. I cleanse (or will cleanse) myself in those two great, stately lakes that are in Heracleopolis Magna, on the day when the rekhyt make offerings to this great god that is within (=the city). What are they? The name of the one is Million / Heh; the name of the other is Sea. They are the Lake of Natron and the Lake of $\mathrm{Maa}^{17}$. Otherwise said: the name of the one is Guide of Millions; the name of the other is Sea. Other (variant): the name of the one is
Germ (or Sperm / Seed / Parent) of Millions; the name of the other is Sea. As for this great god who is therein, he is Re himself.

It is remarkable that some of the glosses that played a marginal role in the MK, since they are only recorded in one coffin, are "standardized" and become the common versions ${ }^{18}$. Set against $\mathrm{CT}$, another new element in the version of BD is the use in some sources of the determinative for deities (강 or after certain variants of the lakes' names (Millions, Seed of Millions and Sea), a fact which shows their embodiment as divine entities ${ }^{19}$.

Both spells insert the generic and concrete names that the Heracleopolitan pools received in the funerary context. They are known under the common designation of $s \check{s} / s \check{s} w y^{20}$, which is usually complemented by positive adjectives $(w r w y, 3 w y)^{21}$.

17. In most of the versions checked, the name recorded is $\check{s} n(y) m^{\Upsilon} 3 t$. A variant in the coffin of Herunefer is closer to the earlier formulae (CT IV, 216/217 a-c [335] according to the gloss in Sq1Sq, which locates the lakes in Naref and Heliopolis -see n. 36-), although it has a version prevously unknown by them. A coherent translation of the passage

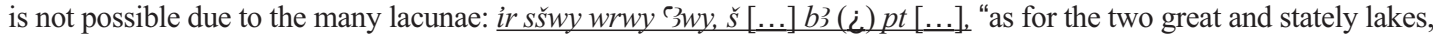
the lake [...] the $b a$ of the sky [...]" (Parkinson; Quirke, 1992: 47, 1. 11). The authors indicate that a formula in the

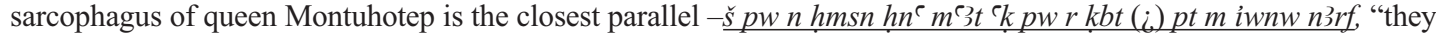
are the Lake of Natron and of Maat, it means to enter in qebet (?) of the sky in Iunu and in Naref'.

18. As regards the version in BH1Br, Schenkel (1975: 64-65) suggests that it represents an intermediate step in the chronological sequence which links the glossed versions of CT with chapter 17 of the BD. Willems assigns it a late date in the group of coffins from Beni Hasan, between the end of Amenemhat II and the beginning of Senusret III (1988: 66-67). Lapp includes it under the siglum BH4 in his type 12-13, belonging to the transition between the 12th and 13th Dynasties (1993: 61-70, 278). Rößler-Köhler argues that the body of the text of chapter 17 of the BD was composed after the CT traditions current in Upper Egypt, especially after the Theban versions with some additions of the formulae from Meir. As regards the glosses, the Theban element also prevails, but some formulae stem from the coffins of Beni-Hasan (1979: 324-325). We must bear in mind that the origin of the new glosses in chapter 17 of the $\mathrm{BD}$ can be traced back either to the time when CT were composed, even though they are not transmited in any of the contemporary documents, or to a later date, when the text is reedited.

19. We are referring to the name "Millions" in pParis Louvre 11085 and pLondon BM 9900 and "Seed of Millions" in the latter and M. Cairo CG 40001+Boston MFA 82.31. However, the name " $w 3 \underline{d}$-wr" can be used either with the determinative of deity as in the papyrus of London mentioned above, or of men as in pLeiden T1, pLondon BM 9901 and BM 10470, pBerlin P. 3002 and pDublin 1661. For the different spellings see Lapp's edition of the text (2006: 80-85). The embodiment of the lakes is further reinforced by their pictorial representation as fecundity figures in the vignettes, as we will show below.

20. $s \check{s}$ is used to refer in general terms to a marsh, lake with birds, pond or nest with chicks $-W b$. III, 483, 12- 485, 2-. For

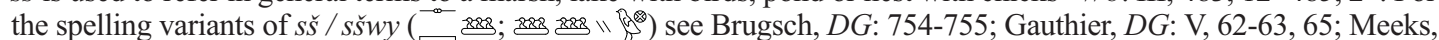
$A L E$ I: 77.3863. Geßler-Löhr, 1983: 27, concedes that the name could also refer to the sacred lake at Sais. Logogram G49 (limits the semantic sphere of the word to those marshy places noteworthy by their ornithologic richness -Diego Espinel, 2006: 87-. Montet relates the term to the funerary scenes on tomb walls of fowling and fishing in marshes (1931: 174). For Gomàa $\check{s}$ and $\check{s}$ are one and the same word (1986: 361).

21. In the following sources $s \check{s}$ (written with logogram G49) can refer to a landmark (either a place or a pond) in the Heracleopolitan boundaries associated with a ram: 1) $m r y b 3 n b s \check{s}$ (without determinative) in a bowl from the time of Pepy I-Brunton, 1927: I, 68, pl. XLI, 17 and pl. XXV, 28-; 2) wttt(w) b3 hry-ib š̌ (with city determinative) .../... 
The dual character of this element might have been devised by the local theological perspective. Instead, it could stem from a special feature of the landscape, possibly reflected in the title "Overseer of the two ponds of birds" (imy-r3 $s \check{s} w y)$, born by several officials of the reign buried in the necropolis of the FIP (fig. 3) ${ }^{22}$. This title was conferred on officials holding the highest civil responsibilities during the late 5 th and 6th Dynasties, whose tombs were erected in Saqqara, Deir el-Gabrawi, Meir and el-Hawawish ${ }^{23}$. Although some of them also held religious offices, nowhere do we find a relationship between the post and a particular god or cult place. The title seems to have been rather connected with personal service to the king and the supervising of palatial activities, such as duck hunting in the marshes and artificial pools ${ }^{24}$.

The transmission of the specific names of the pools stems from the trend towards systematizing figures in funerary texts on the one hand, and on the other from a willingness to supply the departed with the tools of

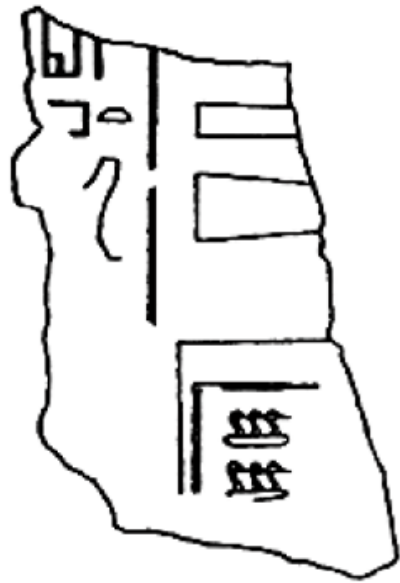

Figure 3: Fragment of Sehu's tomb in the Heracleopolitan necropolis of the FIP inscribed with the title imy-r sšwy; from Padró 1999: 143, fig. 197 (22).

as epithet of Sobek in pRamesseum VI, 23 -Gardiner, 1957: 47, pl. 2, 1. 23-; 3) st tn š̌ rn=f, htp nty hry-šf, nb $n n-n s w, r-g s \breve{s}$ pn. brh imy=fn wsir in the Book of the Fayum -Beinlich, 1991: 166-167.

22. The title is recorded in the tomb of a man whose name is not preserved (Pérez Die, 2005 a: 244; spelled according to a personal communication of the author). Also in that belonging to Sehu (Padró, 1999: 143, fig. 197 (22) and pl. LXIX, 2), and possibly in a fragment of wall found durign the season in 2000 and published as "surintendant des deux marais"-Pérez Die, 2001: 22-.

23. For imy-r3 sšwy see: $W b$. III, 484, 14; Jones, 2000: I, 219, 816; the most enlighting work is that of Wazier (2000), who argues that its singular form (imy-r3s šs) is attested from mid 5th Dynasty until the reign of Pepy II, when it is substituted by the dual form. He points out that there are no differences between the two, since both were used by viziers and high officials. In spite of omitting titles from the FIP, he adds that in the MK the title imy-r šs /sšwy $n$ $s h m h-i b$ was more widely used and that it disappeared in the following period. As regards its duality, he conjectures that it could follow the pattern of other courtly titles split for Upper and Lower Egypt, but prefers to translate the simple and dual version as "Overseer of the marsh of recreation of the king of Upper and Lower Egypt", for he doubts there existed two pools.

[ 36 ] 24. The use of the determinative $\mathrm{O} 1-\square-$ - in certain spellings of the title shows that the bodies of water could have been placed in an enclosed area and that their size would have therefore been limited (Montet, 1931: 175-176). We may conjecture a link between this title and imy-r3 $w h^{\complement} w$, "Director of those who tighten the ropes (=fishermen, hunters)". It is an office widely attested in the OK and the 11th Dynasty among those in charge of fowling and fishing. It is also found in the Heracleopolitan necropolis, in the stela owned by ibnn, who could have been engaged in the supply of the palace, judging from the other titles he bore: imy-r’ pr šnwty; imy-r’ ' $h n w t y$; ' $b 3$ ' $h$ (Pérez Die; Vernus, 1992: 85-87, fig. 5, lám. IX a).

25. Assmann, 1989: 143-144.

26. See Brugsch, $D G: 530,534$ and Gauthier, $D G$ : $\mathrm{V}, 120$, for the variants in spelling. The lake is mentioned in CT IV, $213 \mathrm{e}, 216 / 217 \mathrm{c}$ [335] (=LdSD 17 a $\S$ S 8, Urk. V, 24, 1-5; 25, 1-5); CT V, $257 \mathrm{~b}$ [420]. In the latter it is connected

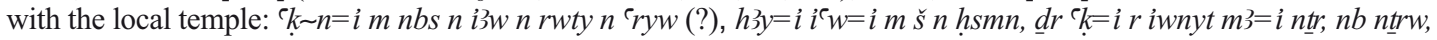
$h r y-\check{s}=f .$. . ("I have entered into the nebes-tree of the mound of the double gate of the two nar-trees' nome, I went down so that I may wash myself in the Lake of Natron, since I entered into the hypostile hall I have seen the god, the Lord of the Gods, Heryshef..."). 
$-\check{s} n m^{9} 3 t^{27}$-, but other designations are attested as well ${ }^{28}$. As regards the former, the determinatives are those we expect to find accompanying natron, a substance used in religious or funerary contexts $(₹)$ and measured out in small bowls $(\circ, \cdots, \ell)^{29}$. The name Lake of Natron served to convey the product found in these waters and which was very useful for cleansing, precisely the activity performed by the deceased in the pools according to the passages translated above $^{30}$.

The sign of an enclosed space, a building or a specific area $(\square)$ is usually added as a determinative to the Lake of Maat ( $\left.m^{\top} 3 t\right)$, but an irrigation channel (II) or less frequently, the horizon sign are also attested (O). Brugsch, Gauthier and Altenmüller suggest translating this landmark either as "Lake of Truth" $\left(m 3^{`} t\right)$, a place mentioned in some spells of BD where mysterious rituals are performed (125 c $\S \mathrm{S} 6)$, or with terms relating to the notion of justice ${ }^{31}$. However, there exists a difference in spelling between the words $m^{3} 3 t$ and $m^{3} t^{32}$, and to our toponomy are never added the determinatives linked with the concept of Truth and Jusctice - 负,,,$\rightleftharpoons$ and variants ${ }^{33}-$. On these grounds, we reject the suggestions of these scholars and the identification of this lake with the one mentioned in chapter 125 of the BD and in the Eloquent Peasant ${ }^{34}$. Some researchers put forward a new etymology, considering that the word is a compound of the suffix $-m$ and the substantivized adjective "the height" ( $(3 t)$, and hence translate "Lake of the Height" or "Lake that is in the height" ${ }^{35}$. The three determinatives mentioned above may indicate that the mythical reflection of this lake was understood not as an abstract concept but as a concrete

27. Wb. II, 46, 7. Mentioned in CT IV, 213 e, 216/217 c [335] (= LdSD 17 a § S 8, cf. previous note).

28. In coffin B9C the names recorded are Lake of Natron and Lake of the Great House (CT IV, $216 \mathrm{c}$ [335]). Since there is no parallel for the latter toponymy in our sources, it can not be ascertained whether it was a unique variant or a mistake made by the scribe in charge of transcribing the texts to the coffin.

29. Coffin B1P bears a unique spelling; a determinative similar to the sign the uniliteral sign $-t$ and the vertical stroke $-Z 1-$ with which are usually written the word city -De Buck, CT IV, 216, n. *- $^{*}$

30. The Lake of Natron does not appear in PT, due to the lack of references to Heracleopolitan elements among these formulas, but waters filled with natron are mentioned in this corpus to cleanse the late king (TP $1140 \mathrm{a} / \mathrm{b}, 1293 \mathrm{c}$, 1902, 1919).

31. Brugsch, $D G: 253,530,1171$, aims at a relationship between this pool and the Lake of Truth of chapters 17 and 125 of the BD, which he located in Naref (id., 248-249); Gauthier, $D G: \mathrm{V}, 117,120$, considers it to be one the sacred pools of Heryhsef's temple or one of the states consecrated to this deity in the necropolis of Naref; Griffiths, 1980: 30-33, translates the name as "Lake of the Justified", without respecting the peculiar spelling of the word. The translation as "Lake of Truth" has been rejected by Assmann, 2005: 319-321.

32. The following are some of the most representative spellings of $\check{s} n(y) m \underline{c} t:$ $\triangle$. For the variants of CT 335 see De Buck (1935-1961: CT IV, 217-218) and of chapter 17 of the BD,

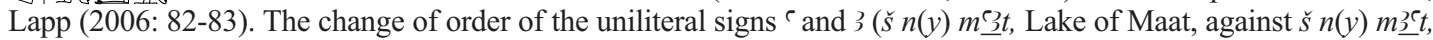
Lake of Truth/Justice) can not be ascribed to a scribe's mistake, since it is a feature found on most of the published coffins and papyri. However, most of the scholars that analyze this passage translate the name of the lake erroneously, changing the position of the signs.

33. is only attested in the following versions of chapter 17 of the BD: coffin of queen Montuhotep; pDublin 1661 and pParis Louvre E. 11085. The rest of sources use the signs $\square$ or $\square$.

34. ir $h 3=k r \check{s} n m \jmath$ t, $s k d=k i m=f m m 3$, "if you go down to the Lake of Maat/Justice, you will travel in it with the breeze" -B1 85-86 and R 14.3 in Parkinson's edition (who highlights the use of the name of the lake as a means of introducing a local topographic element in the tale-1991: 77, n. 16-) and B1 54-55 in that of Lefebvre (2003). Here the term $m 3^{\top} t$ rounds out a nautical metaphor in which the idea of sailing through a water surface named Lake of Truth is linked to the notion of behaving with rectitude and imposing justice. It rests upon a play of concepts and words similar in sound: sail $-s k d-$, build $-k d-$ and mood $-k d-$. A play on words between Truth $\left(m^{3} t\right)$ and breeze $\left(m^{3}{ }^{\top} w\right)$ is also noticeable.

35. See Geßler-Löhr, 1983: 147, following a suggestion of Rößler-Köhler, 1979: 216, Anm. 7. Barguet's hypothesis (2000: 58, n. 15) to link the term with $\mathrm{mm}^{3}$ ', used for a type of myrrh only documented in the Ptolemaic Period ( $\mathrm{Wb}$. II, 59, 4), seems to us somehow risky. 
area. It could have even been located in the sky, near the horizon, an idea that fits in with the mythemes of purification and solar rebirth that dominate the passages translated.

The two pools are also mentioned under other names ${ }^{36}$. Those connected with the Lake of Natron are distinguished by the variation of the first element $-m w t$, ' $m$, wtt, sšm/šmt- and the repetition of the second one $-h h-$. The Lake of Maat on the other hand is usually referred to as Sea. The variety of designations has been explained by the existence of local traditions in Thebes, Meir or Saqqara (places of discovery and presumably also of production of coffins inscribed with spell CT 335). But the consistency within this variety may be due instead to the availability of a wide range of glosses in the manuscripts used by the scribes who decorated the coffins.

The type of names mwt hh, ${ }^{\top} m$ h h, wtt hh, taken in their meaning of "Mother of Millions or
Endlessness" ( $m w t$ hh) or "Seed of Millions or Endlessness" (wtt hh) can be associated with the notion of water as a symbol of a very fertile (hence the term "Millions") power of germination or fecundity (hence "Mother" and "Seed") 37 . They can also refer to the primeval chaotic element, "Endlessness" being thus the image of the boundless nature of the Nun. In other funerary formulae, these same names designate the guardians of doors that lead to secluded and sacred places $^{38}$. They can be used as epithets of Horus ${ }^{39}$ or $\mathrm{Shu}^{40}$ as well. The latter case is specially suitable for our context, since there is a link between the mythology of this god of light and dryness and the funerary role of solar rebirth attached to the Heracleopolitan lakes. Concerning $w 3 \underline{d} w r$, which is usually translated as "Great Green", it is a place mentioned in the earliest funerary corpora (PT) and some texts of self presentation. It stands as a watery region, more precisely as a liquid extension in heaven that the deceased wishes to cross, sometimes with the purpose of ascending to the sky ${ }^{41}$. The symbolism behind this word is

36. The following are the glosses found in CT: 1) $\check{s} p w n h s m n, m w t h h r n=f, h n^{\ulcorner} \check{s} n m\ulcorner 3 t, w 3 d w r r n=f$, "they are the Lake of Natron, its name is Mother of Millions (or of Endlessness or Heh-gods, with determinative S $^{\prime}$ ) and Lake of Maat, its name is Sea" -CT IV, 216 a-c [335] T1C a, de Buck, CT IV, $409 * 4-6-$. The same gloss was inscribed in a coffin published by Grapow, 1915-1917 (document H, coffin of itpw in San Petersburg): Urk. V, 2, 8; text in Urk. V, 23, $5-10 ; 2)$ ' $m$ hh $r n=f$, w3d wr $r n k(y)$ "Swallower of Millions (or of Endlessness or of Heh-gods, mixed determinative between deity -A40- and Heh-god -C11-) is the name of the one, Sea is the name of the other" -CT IV, 217 e-d

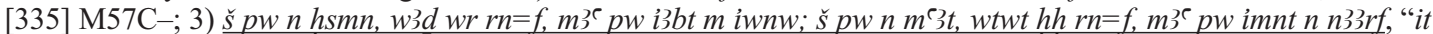
is the Lake of Natron, its name is Sea, it is the eastern shore in Iunu (Heliopolis); it is the Lake of Maat, its name is Seed (or Germ or Father) of Millions (without determinative, but the spelling follows one of the ways of writing the name of the Heh-gods according to $\mathrm{Wb}$. III, 152, 11), it is the western shore in Naref' -CT IV, $216 \mathrm{c} ; 219 \mathrm{c-g}$ [335] Sq1Sq-. The versions in chapter 17 of the BD take up the first two variants and introduce $s \check{s} m / s m t h h$ and $h h w$ (see Geßler-Löhr, 1983: 220-221; Lapp, 2006: 84-85). In the case of compound names with the term $h$ h, two logograms can be used (C11 and A73) and the plural is marked by three strokes or three dots (never with the eight strokes that point to the Hermopolitan Ennead).

37. Blackman emphasizes the idea of fertility underlying the name of the lakes. He considers it to be linked with the presence of elements that are masculine ("Seed of Millions" refers in his view to Atum's seminal liquid) and feminine (hence "Mother of Millions") inside them -1921: 75-76; see also Geßler-Löhr, 1983: 148.

38. In CT IV, 312 b- 316 a [335] = Urk V, 66, 5-67, 5, ${ }^{\mathrm{C}} \mathrm{m}$ hh, is the guardian of the Lake of the Flame (the same spell is found in BD $17 \mathrm{~b} \S \mathrm{S} \mathrm{3}$, that adds information about the location of this lake between Naref, a necropolis and a centre of cult of a local form of Osiris near Heracleopolis Magna, and the Residence. This name is only attested in the

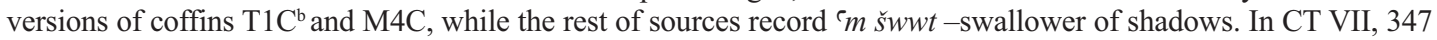
$\mathrm{f}[1076],{ }^{\mathrm{C}} \mathrm{m} h \mathrm{~h}$ is included in a list of names of genious, depicted with scarab heads and lizards in their hands.

39. In CT VII, $46 \mathrm{n}$ [841] it is announced: ink $h r$ ' $m$ h h. "I am Horus, the swallower of Heh-gods".

40. ink wttt(w) hhw whm $m$ h h again in the endlessness, in the abyss, in the darkness. It is I who am Shu, begetter of the gods" - CT II, 5 e-6 b [76]. Translation and anaysis of this passage in Allen, 1988: 18-21, who prefers rendering "I am the begetter of repeated millions ...".

41. $w 3 \underline{d} w r$ can symbolize either the abundance of resources or a privileged space for fowling, where the deceased can quench his thirst and hunger (Assmann, 2002: 377-378 § 28; id., 2005: 131-134). The image of a pond full .../... 
in harmony with the mythical function of purification and rebirth that the texts ascribe to the Heracleopolitan landmark.

\section{Iconographic Analysis of the Scene of the Heracleopolitan Lakes in Vignette of Chapter 17 OF The BD}

The most striking innovation of the versions of CT 335 edited from the NK onwards (chapter 17 of the BD), together with glosses not recorded in previous compositions and the introduction of new mythological topics, is the insertion of a vignette where the stages of rites and myths are linked together ${ }^{42}$. We are dealing with a complex frieze of images, composed of individual scenes with multifarious small details, which are subject to enlargement and reduction, review and standardization with the passage of time. Appendix I contains a full catalogue of documents dated between the 19th Dynasty and the Graeco-Roman Period bearing the image of the Heracleopolitan lakes, on which the following discussion is based. In this frieze, the pools are depicted together with a range of divine figures and symbolic objects, that are recurrent though not standardized and are also subject to diachronic changes in iconography and meaning. The detailed examination of each document quoted in Appendix I has been carried out through the analytical and chrono- logical tables I-XI. Based on these, an ideal or generic image of each period, i.e. with no direct correspondence to any particular papyrus, will be delineated, while the most prominent features and outstanding exceptions will be highlighted. The analysis will proceed in chronological order, and, where possible, also in geographical order, according to the different workshops identified in the Ptolemaic Period. Our aim is to evaluate the meaning of the scenes and the scope and significance of the iconographic variants, as well as to sort the documents of unknown provenance in one of the three known areas of production.

\section{The scene of the lakes in the New Kingdom}

The earliest manuscripts to add images to the text of chapter 17 of the BD date from the 18th Dynasty. Since none of them includes the frieze that characterizes sources from the 19th Dynasty onwards ${ }^{43}$, Munro concludes that the vignette was created after the Amarna Period. Our analysis of the primitive image of the lakes rests therefore on Ramesside papyri whose area of provenance is Theban, Memphite or unknown (figs. 4-6). We have also taken into account certain elements used in the decoration of tombs (walls and funerary furniture) belonging to the highest social groups (kings, royal wives and high officials) of the Theban and Thinite areas (fig. 7$)^{44}$ that in-

of birds recalls the main element of the title imy-r3 sšwy, a possible source of inspiration for the dual nature of the lakes in the funerary formulae. Outside our mythological context, the term can allude to other extensions of sweet water such as the marshy areas around the Delta, rich in birds and fish, or the Fayum (Baines, 1985: 182; Diego Espinel, 2006: 91; Vandersleyen, 1991, who rejects the translation as sea found in Wb. I, 269 and concludes: Ouadj Our est donc une zone verte, luxuriante, baignée d'eau fluviale; c'est généralment une désignation du Delta mais on peut le trouver en d'autres lieux). The meaning and use of the term in the OK in PT and reliefs of royal funerary temples is analyzed by Diego Espinel, 2006: 89-92. The autor stresses the relationship between $\breve{s}$ and $w 3 \underline{d}-w r$ in this corpus of funerary literature (as in PT $707 \mathrm{a}-\mathrm{b} ; 2186 \mathrm{~b} ; 1752 \mathrm{a}$ ).

42. For the new mythological topics see Shalomi-Hen, 2000: 17. A brief survey of the vignette of this chapter in Munro, 1988: 67-68 (based on 18th Dynasty papyri); Hornung, 1990: 423-424; a thorough diachronic analysis of the LP vignettes in Mosher, 1990: 158-195 (see also Apendix D and Table 3) and Milde, 1991: 31-54. Limme, 1983, insists on the importante of studying the vignettes which complement this type of texts.

43. For the illustrated manuscripts of the 18th Dynasty see Munro, 1988: 67-68. None of the figures depicted can be regarded as the prototype of the image of the lakes.

44. In these documents there was a choice of a shortened version of vignette of chapter 17 of the $\mathrm{BD}$, where the lakes were omitted: pNew York Brooklyn Acc. 35. 1448, nfr-rnpt, 19th/20th Dynasty; unknown provenance, Bellion, 1987: 93; TT 1, sn- $n \underline{d}$, time of Rameses II, Deir el-Medina; sarcophagus of $p 3-\check{s} d w$ (TT 3), reign of Rameses II, Deir el-Medina, Zivie, 1979: pl. 29. 


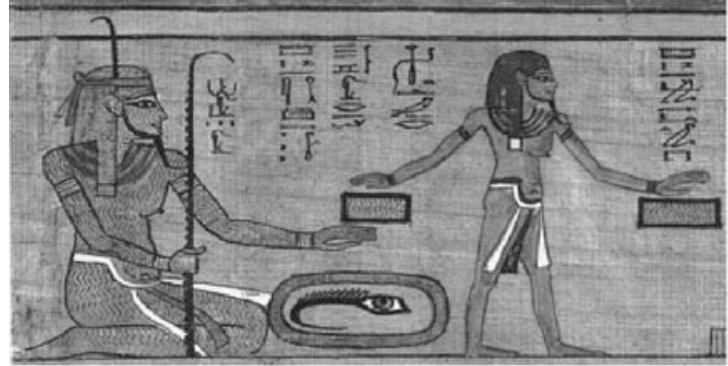

Figure 4: pLondon BM 10470, 19th Dynasty; from Geßler-Löhr 1983: Abb. 46.

clude the scene. Since the latter could have been executed following a master copy outlined first on perishable materials, there is a link with the former sources on papyri.

In general terms, the scene is composed of two figures ${ }^{45}$ facing to the left or right. The orientation of the characters seems to determine the direction of other elements in the composition, such as the items held in their hands and the eyes inside the ovals. They are portrayed in almost all sources as male fecundity figures ${ }^{46}$, except in the few instances where a single male bearing a divine and dignifying mark, most often the curved beard, is depicted ${ }^{47}$.

A characteristic of the images in this period, which contrasts sharply with later reproductions, is the richness of colours. Thus, wigs are usually painted blue or green, are very voluminous but lack ornaments, ex-

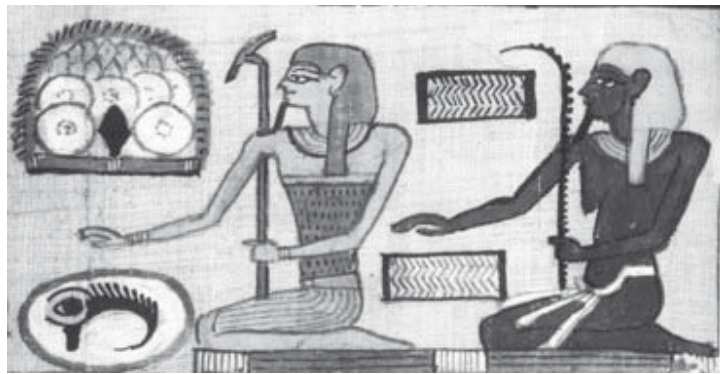

Figure 5: pLondon BM 9901, 19th Dynasty; from Faulkner 1994: 46, below.

cept for three documents in which figures show: a renpet branch tied to the head by a lace (in the tomb of Anhurmose -fig. 7-), a palm branch notched and similarly worn (in pLondon BM 10470 -fig. 4-), a clump of papyri (in TT 135). Significantly enough, the two first cases belong to the reduced group of sources in which the names of the figures are recorded. In both instances the character wearing the ornament is known as Heh. We wonder if behind the simple ornament lies a graphic and phonetic pun, built on the name and attribute of this deity.

Concerning the bodies, a range of blue and green colours has been chosen. Both have symbolic connotations of fecundity, conveying the idea of water, life, freshness and rebirth, all of which are closely tied to our lakes in the Beyond. We also find red and yellow, closer to the tones used in earlier depictions of fecun-

45. This statement can be extended also to the few instances from the period in which a lacuna in the papyrus or in the wall decoration has blurred the traces of one of the characters as in pBerlin $3002 \mathrm{a}-\mathrm{z}$ and TT 32.

[ 40 ] 46. When identifying the characters as fecundity figures we follow the typological features distinguished by Baines: pendent breasts with marked nipples, prominent belly, body corpulence, curved beard, divine wig, etc. (1985: 85-101). Since the figures of our scene are usually masculine, we will describe them simply as fecundity figures and will highlight only those instances where feminine features are prominent (narrow waist, lack of belt emphasizing the creases of fatness in bellies, larger and more voluminous wig with a lock hanging before the shoulder and the rest of hair over the back, lace around wig). Their consideration as feminine fecundity figures should be taken with some caution, since Baines remarks that their identification remains doubtful and that they are not attested after the OK (1985: 110-111, 118-122).

47. The following two exceptions should be set aside as unique instances. In the left wall of KV 10, all divine marks of one individual have been omitted. Whether the representation was intended as such or not, can not be ascertained, since the decoration of the tomb remained in the stage of preliminary sketch; many figures are only outlined and few elements are painted (see n. 11 and 12 in table II and compare with the right wall, where fecundity figures were clearly portrayed). In TT 32, the damages in the torso of the character have blurred the hypothetical depiction of pendant breasts, which distinguish fecundity figures from single male characters. 


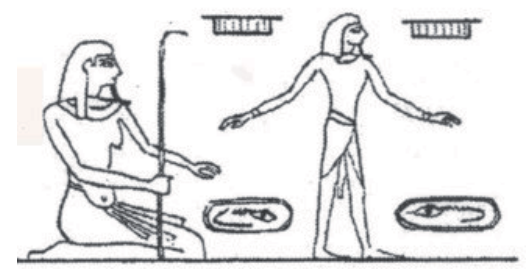

Figure 6: pLondon BM 9949, 19th Dynasty; from Naville, Tb, A.p., Taf. XXVIII.

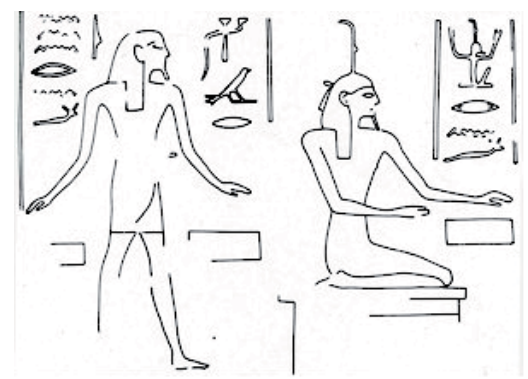

Figure 7: Tomb of ini-hrr(t)-ms, 19th Dynasty; from Ockinga; Al-Masri 1990: pl. 9.

dity figures ${ }^{48}$ and to the conventional colour of male flesh in painting. To strengthen the fertility symbolism, in a small number of sources the bodies show horizontal and vertical lines, which may be occasionally extended to the wigs as well (as in pLondon BM $10471+$ BM 10473; pLondon BM 10470 -fig. 4-; pDublin Inv. 1661).

Two of the most common arrangements of the scene are: one figure standing and the other kneeling; both depicted on their knees. Inside this general scheme there exists a whole variety of attitudes: the kneeling characters can be placed over mats (fig. 5) or podia (fig. 7) or more frequently directly on the ground ( figs.
4 and 6), can hold objects or remain with free hands. When portrayed standing, they stretch out their arms in opposite directions and hold no objects, while if kneeling, the arms are stretched in the same direction (towards the front), except in TT 32. In both postures, the way of depicting the body follows the Egyptian canon; the whole width of the torso is shown, but only one breast marked.

The palm of the free hand is always turned down in a gesture of protection, while the other hand holds objects of different kinds. The renpet-sign is the most usual, whether it shows one or several notches $(\{, \tilde{I})$. It is linked with the idea of unlimited time and with the Heh-god, impersonating eternity and endlessness in one of his aspects. Ocasionally, two different elements are attested: the ankh-sign $f$ (in pDublin 1661) and the was sceptre ? (in pLondon BM 9901), both being attributes of deities bestowing on their bearers powers and the capacity to endow with breath. Generally, only one object is represented, but we attest omissions, reduplications ${ }^{49}$ and depictions of two different elements (pDublin 1661) in isolated instances.

As to the objects protected under the palms, eyes and pools are particularly evident. The former is usually composed of a pupil from which hangs a vertical appendix, a noticeable feature of the wedjat-eye ${ }^{50}$. One side of the external corner of the eye is curved towards the inside while the other shows oblique lines: D? $^{2}$. As it is characteristic of hawk deities, we will call it "feathered eye". Commonly, it faces the same direction as the two figures, except in the case of the image in the cenotaph of Sety

48. Baines, 1985: 110, though we do not dismiss the association of the red colour with life. Blue tones in fecundity figures are first attested in the temple of Nyuserra and become usual in the NK, owing to its symbolic prestige and its links with water and the primeval flood (id.: 141, 149).

49. In JE 27032 the figure holds two renpet-branches -Desroches-Noblecourt, (coord.), 1976: 202-. The image was included in the funerary monument of an artisan in charge of decorating the royal tombs. He had therefore access to the repertoire of funerary scenes intended for members of the royalty, among which was included the vignette of chapter 17 of the BD (KV 10, QV 66...).

50. Even though most scholars describe this eye as wedjat the distinctive tear with its winding end $\rightarrow$ is not depicted before the 26th Dynasty. 
I and in symmetric compositions, where two opposite eyes are flanking a standing figure ${ }^{51}$. The eye is enclosed in an oval ${ }^{52}$ that rests upon a surface (be it the groundline, a mat or exceptionally a pedestal as in pLeiden T4) or is slightly above it.

The second object mentioned, the lakes, usually come in pairs ${ }^{53}$, either aligned at both sides of a standing figure (fig. 4), or superimposed, above and below one of the arms of the kneeling character (fig. 5). Few documents bear witness to this second pattern. They are always depicted high over the groundline, but in pDublin 1661, the lower one rests directly over the mat. In general, its contour tends to the rectangular shape $(\square)$, but can come closer to a channel as in pLeiden T4 ( $匚$ ). Some manuscripts detail the bottom $(\rightleftarrows)$ or its content by means of vertical waves (

In pLondon BM 9949 we find a noticeable variant of this scheme (fig. 6). The elements are arranged symmetrically around a deity with arms stretched out in opposite directions. Under his palms are placed two ovals+eyes facing each other and over his arms two horizontal doors with opened leaves ${ }^{54}$. The image is remarkable in itself for the omission of the lakes, or rather, their substitution for doors ${ }^{55}$. The latter are not a feature alien to the iconographical and textual content of CT 335 and chapter 17 of the BD. In fact, they are a recur- rent item in the vignettes of this chapter, either placed inside a naos-like structure or over the horizon sign. Moreover, in the text itself there are many references to the sacred portals of the horizon through which Atum (and the deceased) proceeds before emerging shining every new dawn. Doors thereby connote the ideas of rebirth and life.

The names of the figures in the scene are only recorded in the papyrus belonging to Ani (fig. 4) and in the tombs of Djehutymes from Thebes (TT 32, partially preserved) and of Anhurmose from el-Mashayikh (fig. 7) ${ }^{56}$. In the papyrus, the pool set between both figures is called Lake of Natron $-\check{S} n(y) h s m n-$ and the one to the right Lake of Maat $-\check{s} n(y)$ $m^{\mathrm{C}} 3 t-$. The standing individual is named Sea $-w 3 d t-w r i-$ and shares with the only other instance where the name of this character has been preserved (TT 32) the attitude of protecting the pools. The kneeling figure is called

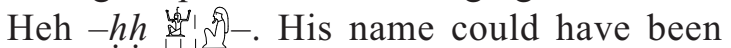
written by means of a graphic pun: the two branches worn on his head and hand would stand for the uniliteral sign $h(h h$, since they are two) and the figure itself for the determinative of deity - 角 - . A similar procedure could have been rehearsed in the tomb of Anhurmose, for the person with a branch tied to his head is also called $h$, although he does not held a second stem to render the visual pun complete.

51. pLondon BM 9949 -fig. 6- and possibly also pLeiden T4, for which see n. 6 in table I. The pattern of symmetry that guides these scenes does not recurr in later periods, but is a characteristic of the vignette in chapter 125 of the $\mathrm{BD}$ as will be shown in a future article.

52. In KV 10 it is a perfect circle (a geometric shape that will show up again in later documents) and the form of the eye inside has been oversimplified -nearly distorted: Lefebure, 1889: pl. 56.

53. In the tomb of Anhurmose three lakes have been depicted (fig. 7), an exceptional fact in the light of the reference to only two pools in the funerary spells translated above. See n. 17 in table II.

54. A similar symmetric pattern could have been used in pLeiden $\mathrm{T} 4$, but the image is only partially preserved. We can only hint at the representation of two pools (in the shape of a channel) and two feathered eyes+ovals over a pedestal, arranged according to an axis of symmetry.

55. In the tomb of Bekamon (TT 135) of the 19th Dynasty, instead of two lakes, only two feathered eyes inside ovals have been represented. Despite publishing only half of the scene, Baines states it is symmetric (1985: fig. 185). The peculiarities of this document are remarked in $n .15$ of the table II.

56. The primeval intention was to write down the names of the items in the scene also in TT 135, and althoug enough space was left for the purpose, the recording was never accomplished (see n. 8 in table II). 
The four names given in the papyrus of Ani to the figures and pools on the one hand and assigned to the Heracleopolitan lakes by the different glosses of CT 335 and chapter 17 of the $\mathrm{BD}$ on the other are the same. Owing to this fact, certain scholars conclude that the figures embody the same lakes that they protect ${ }^{57}$. We endorse this suggestion and extend it to the rest of documents on the following grounds: the identification of items by means of their names in other sources and the association of characters and basins which is strengthen by their epithets, iconography (as fecundity figures) and the prominence given to symbolic colours linked with water.

\section{Sources from the 21st Dynasty}

This period witnesses a fall in the number of documents with the image of the lakes, and a geographical and social confinement to the Theban area and to the high clergy of Amun also takes place. Only three papyri display the scene, being reduplicated in one of them (pLondon BM 10554 -fig. $8{ }^{58}$ ). A fourth document could have also included it, but is too damaged to be taken into account. Five sources of the period prefer shortened depictions of the vignette, in which the motif we are analyzing is suppressed ${ }^{59}$. Niwinski has remarked that in this period the increase in the number of spells in this funerary corpus on the one hand and in the demand and value of papyri on the other, led to: the selection of formulae; curtailed texts and images; the compression of several chapters into one vignette and, the use of the latter as a substitute for the whole

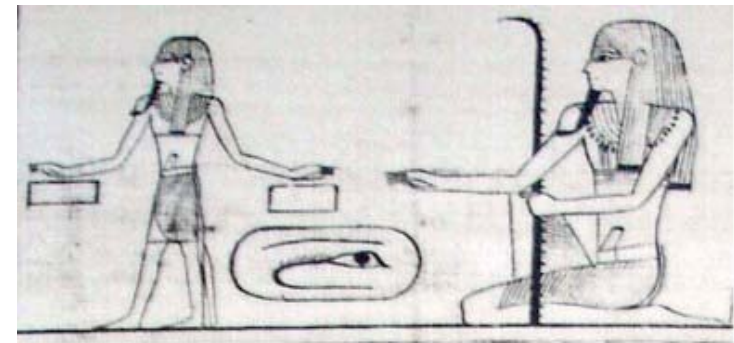

Figure 8: pLondon BM 10554 (=pGreenfield), early-mid 21st Dynasty; from Budge 1912: pl. X.

chapter. Abbreviations and amalgamations could render the original text unintelligible, but did not deprive it of magical efficacy ${ }^{60}$.

Sources from the 21st Dynasty follow the Ramesside pattern and introduce significant variants. In the first place and most outstandingly, male characters that may or may not wear an attribute of divinity or power (curved bear, bull's tail) are used instead of the usual fecundity figures. Secondly, the fusing of the dual image of the lakes in a single figure is attested for the first time. Thirdly, the wide range of body postures from the preceding period, gives way to the combination of a standing character with arms stretched out in opposite directions and a seated figure with one arm extended towards the front and the other holding a branch. Finally, it is striking that the general orientation of the figures has ceased to dominate the direction of the rest of the objects in the scene.

There is also a general decrease in details: wigs do not bear ornaments; no waves deco-

57. Seeber, 1976: 66; Baines, 1985: 382.

58. See n. 20 in table III for a possible explanation.

59. 1: pLondon BM 9948, diw-sw-n-mwt, mid-late 21st Dynasty, [Thebes], Bellion, 1987: 52, Niwinski, 1989: 322 (London 8); 2: pTurin 1818, nsi-hnsw, 21st Dynasty, [Thebes], Bellion, 1987: 278, Rößler-Köhler, 1999: 124-125); 3: pCologny CI, ' $n h-f-n-h n s w$ and pCologny CII, $t 3-n t-i m n t t-h r-i b$, [Thebes]. These three sources belong to the same workshop and to owners bearing the same titles (except pCologny CI); 4: pCairo S.R. VII 11496, $t 3-w d \underline{d} 3 t-r^{\complement}$, mid 21st Dynasty, Thebes, Royal Cachette of Deir el-Bahari, Piankoff; Rambova, 1957: 133-142 (No. 15), Niwinski, 1989: 295 (Cairo 118).

60. Niwinski, 1989: 20-22, who terms the method of effective merging/fusion as pars pro toto rule. For other reasons adduced for the rise in the number of papyri in this period see $i d:$ : 34-45. The same opinion is held by Mosher (1990: 439-440). 
rate the bodies or the surface of the lakes; the names of figures and items are not recorded; from the variety of objects held, only branches with several notches remain.

As for the objects protected, the emphasis is on lakes: the dual nature continues to be characteristic; the only manuscript protraying the merged image omits the feathered eye, but not the pool. Moreover, in another document (pBerlin P. 3157) the eye has been replaced by a bowl of stone $(\square)$, the symbolism of which is closely tied to the purification rites ${ }^{61}$ and thus to the role of the lakes.

A final trend is attested in this period of bewildering creativity in the funerary imagery: it has been suggested that chapter 17 functions as a sort of summary of the whole corpus of BD and that many images included in its frieze of vignettes recur as independent scenes in other chapters. Among the latter we may recall the images of Isis and Neftis mourning and protecting the mummy, the heavenly cow, the benubird ..., but the scene of the lakes is attached only to this specific formula. However, a manuscript interpolates in the vignette of chapter 110 of BD a kneeling figure, with arms directed towards the front over a rectangle ${ }^{62}$. Although it bears a close resemblance to the one we are concerned with, it seems to be an element foreign to the the $h t p w$-fields, since it is attested in no other source that includes this chapter.

\section{[ 44 ] The scene during the 26th-30th Dynasties}

After a short period in the 9th century BC in which the funerary manuscripts disappear and the decoration of coffins undergoes a drastic reduction, the previous tradition is resumed in the 26th Dynasty. It is then that the compilation of the so-called "Saite recension" takes place. The "classical" sequence of chapters is fixed, and the vignettes are standardized, though by no means turned into canonical compositions. In the course of ages, the number of documents on papyri and mummy bandages bearing our scene increases, the places of provenance of sources diversify (Thebes, Memphis, Heracleopolis Magna, Abydos and Meir) and the local traditions begin to loom. We choose to examine these dynasties together owing to the continuity in arrangement and style of the vignettes. Furthermore, certain documents do not lend themselves to accurate dating and have been placed largely between the Saite Period and the last native dynasties.

As the number of papyri increases, modifications to the primeval pattern devised during the 19th Dynasty are introduced. Even though fecundity figures regain prominence, the presence of two women, with slim bodies outlined by long and tight dresses, is attested for the first time in a Theban manuscript (pCairo S.R. IV 692). The sources from Late Dynastic times show a preference for kneeling characters that extend their arms in the same direction and sometimes hold an object. Moreover, the orientation towards the left dominates and will be one of the main features guiding the schemes of the Graeco-Roman Period (figs. 9 and 10$)^{63}$.

The result of the increase in papyri decorated with outlined figures (in black ink with a few touches of red) is the reduction of details and the simplification of anatomical forms. Scribes also give up the rich and symbolic palette of

61. Wilkinson, 1992: 202-203.

62. pCairo S.R. VII $10249=14.7 .35 .5=$ CG 4885, wsr-h3t-ms, mid 21st Dynasty, Thebes, Royal Cachette of Deir el-Bahari; Seeber, 1976: 203 (5); Bellion, 1987: 103, dates it to the 19th Dynasty; Munro, 1988: 297 (Nr. 4), assigns it to the 19th/20th Dynasty; Niwinski, 1989: 283-284 (Cairo 86), pl. 24 c; Gesellensetter, 2002: Kat Nr. 62, Taf. 7.1.

63. Mosher already pointed out that the standardization in the LP also affected the orientation of the characters in the vignette, so that the deceased (and also our figures) usually looks towards the left, while deities look towards the right (1990: 125-128) 


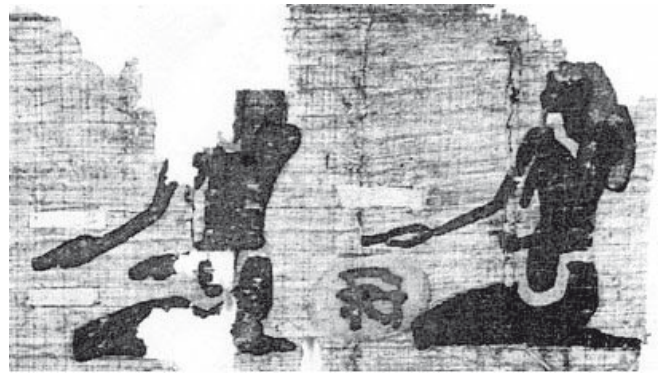

Figure 9: pColonia Aeg. 10207, 26th Dynasty; from Verhoeven 1993: III, beilage 3.

colours peculiar to NK manuscripts. It is remarkable that the only instance representing two women, green and blue colours have been chosen respectively for the dress and the wig, stressing their link with vegetation, water and fertility. The same symbolic chromatic range is used in a limited number of sources (fig. 9). The reduction of details, which had already been noted in respect of the 21st Dynasty, pervades all scenes: wigs bear no ornaments, bodies include no watery waves and names of figures and items are not recorded.

A new trend with far-reaching effects in the Ptolemaic Period is already noticeable in the late pharaonic epoch: the change in the protective attitude of both figures or its combination with a new gesture. In two Theban examples (pParis BN 94-95 y 112-117 and pVatican $\mathrm{N}^{\circ}$ Inv. $38.571-$ fig. $10-$ ), one of the individuals stretches his arm to the front, but the palm is turned up and the object is depicted above, so that the act conveyed is that of offering, not the hitherto common protective gesture ${ }^{64}$.

Other peculiarities may be pointed out: not only is the typological range of eyes and lakes wider, but new elements symbolizing protection and offering are introduced. In feathered

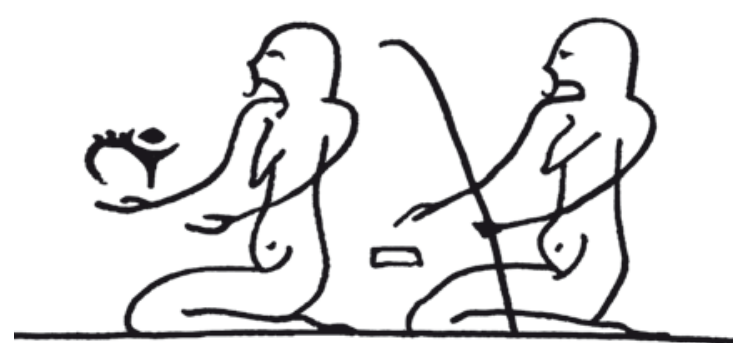

Figure 10: pVatican $N^{o}$ Inv 38.571, last native dynasties; drawing by N. Delgado after Gasse 1993: pl. XXXI.

eyes, the pupil (pNew York MMA 35.9.20) or the oval (pVatican $\mathrm{N}^{\circ}$ Inv. 38.571 -fig. 10-) may be omitted. To this type, ubiquitous in previous compositions, are now added: the wedjat, one of the emblematic elements of the funerary iconography; the simple eye, composed of cornea and iris; the eye we have dubbed "simplified version", in which a simple sketch does away with the typical features of the other types of eyes (pLondon BM 10558). As for the orientation, the pattern of the NK -facing in the same direction of the figures- is resumed with few exceptions.

Regarding the pools, new features include the modification in a small number of papyri of the rectangular and elongated shape common heretofore and the loss of the dual nature. In pVatican $\mathrm{N}^{\circ}$ Inv. 48.832 and pNew York 35.9.20 two basins are shown, but the contour of one of them is close to a cube and rests on the ground on one of its shorter sides. Moreover, the hand of the protecting figure next to it actually touches its surface, so that the lake resembles a piece of furniture (a table or low altar). At the same time, the characteristic duality of the pools gives way to the depiction in some papyri of only one lake ${ }^{65}$. The eye can even become the dual object (as in pLondon

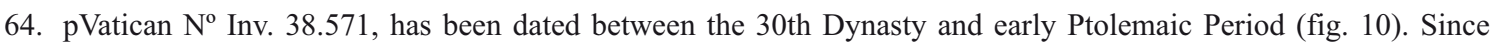
during Ptolemaic times and in the Theban area of production, the mixed scheme (one figure offering an eye and the other protecting a basin -fig. 12-) becomes a usual motif, this papyrus could be better included inside this group of late date.

65. As an exception we may cite pColonia Aeg. 10207, dated to the 26th Dynasty, remarkable for the depiction of three lakes (fig. 9). For the only parallel of Ramesside times see n. 53 and in table II n. 17. 
BM 10558), but without following the symmetric pattern attested in the NK of opposite eyes flanking a figure (fig. 6).

One manuscript substitutes the eye for a shenring (pTheben 1), to which are attached temporal and solar meanings. Not only does it refer to eternity, but often the solar disc is represented inside a ring of this type as well ${ }^{66}$. Another papyrus seems to have rescued the motif of the door, only attested in the NK, but since the object is partially hidden behind a building its identification is rendered difficult and not precise ${ }^{67}$. For the first time we witness the suppression of all objects symbolizing the purification and rebirth that were protected or offered in previous times. Its memory nevertheless survives in the act of protection performed by one of the characters, when he turns his hand down, but the hand hovers over a void space (pParis Louvre N. 3094).

Finally, the new elements introduced in this period of revision also influence the objects held in the hands. Though palm stalks are prominent, in one instance (pNew York 35.9.20) the notches are projected on both sides of the stem, so that the result comes close

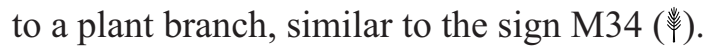

\section{Modification of the image in the Ptolemaic Period}

In the Ptolemaic Period the number of manuscripts undergoes an astonishing increase. Sev-

[46] eral changes that are foreshadowed in the previous stages come to prominence during this period, so that the process ends in the reinterpretation of the meaning of the lakes' image, a fact especially remarkable in the so-called Akhmin tradition, but also noticeable in oth- er sources. This section has been divided according to the variously identified workshops where papyri were produced (Thebes, Memphis and Akhmin). Documents of unknown provenance and those executed over mummy bandages have been included at the end of this epigraph. Owing to their wide inner variation, the analysis will not aim at drawing out common features, as will be done with the papyri stemming from the centres of production mentioned above. Instead we will try either to fit them into one of the recognized traditions or to highlight their uniqueness. If the latter is the case, we do not discount the possibility that they belong to a hitherto unknown workshop based on another local necropolis ${ }^{68}$.

\section{Thebes}

The Theban tradition comprises the higher number of documents and its main feature is the predominance of fecundity figures (figs. 11-13). However, in one isolated instance (pLondon BM 10037) they have been substituted by women, wearing tightly-fitting dresses that stylize their waists and stomachs, but do not hide their pendant breasts. Another common trait is the orientation to the left. Despite the preference for the depiction of two characters, at times the image can be merged into one single figure (pDetroit 1988.10; pLeiden T 20), a feature that goes back to the 21 st Dynasty. As for the body posture, the kneeling position with outstretched arms towards the front predominates. This is to the detriment of figures with one arm extended and the other holding an object and especially of standing characters, only depicted in pMailand E. 1028 a- f.

While a few vignettes are polychrome and show individuals of rounded shapes, the ma-

66. Wilkinson, 1992: 192-193. As a symbol of endless time, the shen-ring usually appears together with other elements that convey the same idea, such as renpet-branches and the god Heh, both of which are recurrent in our scene. In pTheben 1 the interior of the ring has been painted yellow (a colour used for representations of the sun).

67. pVatican $\mathrm{N}^{\mathrm{o}}$ Inv. 48.832 , see $\mathrm{n} .23$ in table V.

68. Already suggested by Quirke, 1999 a: 90. 
jority of the images are only outlined in black and may include some details in colour. In the former the dominant palette is the one in use since the NK: blue and black for wigs, with unique examples of orange and yellow; a range of blue and green tones for bodies, with instances of more realistic colours (red and yellow). In the latter, the greater stylization of forms goes hand in hand with a reduction in detail. No longer are included waves in bodies and ornaments in wigs, with the exception of pFrankfurt SUB 1, where a clump of lotus flowers has been depicted.

Theban images may be classified into three patterns according to the attitude displayed by the main characters:

1. The predominant scheme in more than a half of the papyri shows the two figures stretching their arms in the same direction and perfoming the act of protection (fig. 11) ${ }^{69}$. Most frequently they shield only one small-sized lake and a single feathered eye that is not inside an oval (except pLondon BM 10097), but is orientated in the same direction of the figures (except in pParis Louvre N. 3149, 3204 B, 3123 bis + 3213). There are variants inside this first pattern that entail either the substitution of the lake by a door (as in pParis Louvre N. $3090+$ N. $3206+$ N. 3198) or the suppression of some items, though the the attitude of protection still remains (as in pParis BN 1/19, pCopenhague AAe 1, pBerlin 3039 and pTurin 1831). The representation of three objects appears once in our sources, in pLondon BM 10257, bearing one feathered eye and two doors. The presence of two identical elements (specially two pools), common in papyri of previous periods, becomes the exception rather than the rule. It shows up in a single manuscript, which presents unique traits for the depic-

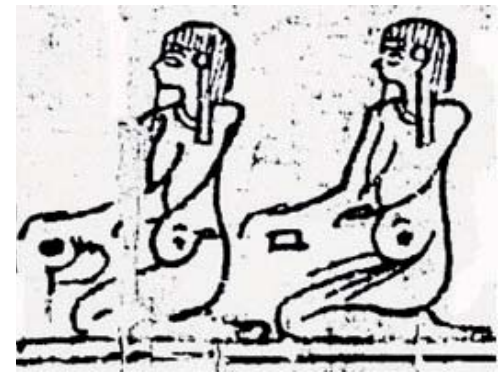

Figure 11: pParis Louvre N. 3089, Ptolemaic Period, Theban tradition, first pattern; from Mosher 1990: pl. 34.

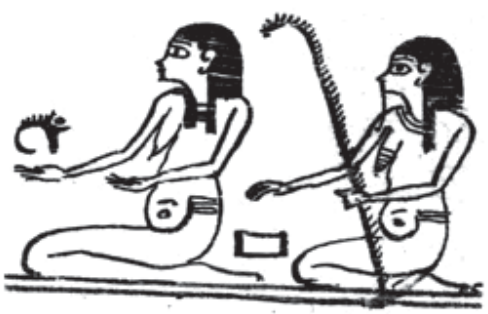

Figure 12. pLondon BM 10086, Ptolemaic Period, Theban tradition, second pattern; from Mosher 2001: pl. 20, 2.

tion of women instead of the usual fecundity figures (pLondon BM 10037).

Inside this group we have also included the type of composition in which the two figures are merged into a single one (pDetroit 1988.10 and pLeiden T 20). Both papyri stand out respectively for the suppression of the feathered eye and the substitution of the pool for two horizontal doors with opened leaves.

2. Our second group (by number of sources) comprises a mixed scheme (fig. 12): one figure performs the offering gesture and the other that of protection. Most commonly, the former offers a feathered eye that is neither depicted inside an oval nor orientated in

69. From thirty-three documents, eighteen include figures in this attitude. In the two instances where the image has been merged into one character, he is portrayed performing the same act. In five cases, the existence of lacunae prevents us from determining which is the gesture enacted by the second individual, though at least the other is depicted in a protective attitude. 
the direction of the bearer. The latter holds a stem with several notches, and stretches his arm in a protective gesture over a single lake or a void space. The exception to this scheme is pMünchen Mon script hierogl. 1, for no object at all complements any of the actions enacted by the figures.

3. In a few documents (pGeneve 23646/ 1-6 and pParis Louvre N. 3087 -fig. 13-) both figures are shown in the attitude of offering. Over their palms are depicted two feathered eyes bearing the same features as the eyes of the second scheme (without oval, orientated in the opposite direction of the figures).

The general reduction of elements in the scene seems to be characteristic of the period. Firstly, it becomes more usual that neither one nor both figures hold(s) any object in the hand(s). Secondly, among items complementing the act of protection or offering are depicted for the first time empty circles and ovals (variations of the simplified version of the eye?), and feathered eyes without ovals outnumber the rest of types (wedjat and simple eye are not attested in this area). Moreover, the suppression of one or both elements is common, and so, above all, is the more frequent use -in comparison with earlier periods- of doors in place of pools (as in pDetroit 1988.10, pLeiden T 20, pLondon BM 10257 and pParis Louvre N. $3090+$ N. $3206+$ N. 3198). The only exception within this South[48 ] ern tradition is pFrankfurt SUB 1. Not only is the size of the lake larger than in the rest of sources, but it rests on the ground and the figure touches it with his hands as well. The reinterpretation of pools into pieces of furniture had already shown up in the previous period but seems alien to Theban workshops. How- ever, as will be discussed below, it is customary in the Memphite tradition, and above all in Akhmin.

Within this area of production, the similarity in style, spelling and arrangement of texts and vignettes displayed in some sources has been useful in order to identify several workshops.

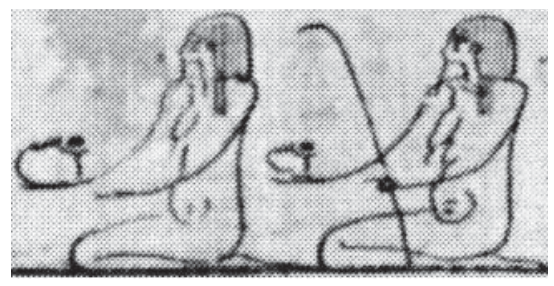

Figure 13. pParis Louvre N. 3087, Ptolemaic Period, Theban tradition, third pattern; from Mosher 1990: pl. 32.

We are referring to papyri Aberdeen ABDUA 84023, 1-7, Berlin P. 3158 A-G and Berlin P. 3159 A-D ${ }^{70}$, which have vignettes bearing a close resemblance, and similar texts, probably owing to the fact of their being executed in the same workshop and belonging to members of the same family.

\section{Memphis}

The Northern tradition stands out because of the social background of the owners of papyri (all belong to the upper strata of priestly hierarchy) and the greater formalism in the arrangement of texts and vignettes. The Memphite scribes favour two different types of figure whose features define two typological patterns. Most documents portray masculine fecundity figures (fig. 15), but in two examples probably stemming from the same workshop, the physi-

70. In the latter source the scene of the lakes has not been preserved, but the rest of the frieze bears a stylistic likeness to the other two documents. The similarites are studied by Munro in Curtis; Kockelmann; Munro, 2005: 53 and fig. A. Mosher also remarks on the similarities between the following manuscripts of the Theban area of production: pParis Louvre 3089 and 3248; pTurin 1971 and pChicago OIM 9787 (for its dating see their entry in our Appendix I). 
ological peculiarities remain somehow ambiguous (pVienna Vindob. Aeg. 65 and pParis Louvre N 3081 -fig. 14-). The typical feminine traits are signalled (long hair tied with a lace, slim waist, tight dress), but their bellies are swollen and the breast is not hidden, but hangs out of the dress or is oversized.

Both, characters and objects, are orientated in the left direction and there is a preference for the sitting posture with arms outstretched to the front, one of which appears in a protective attitude, while the other holds a stem with several notches. Vignettes are executed in black outline, dispensing with colours to depict shapes that are still in use in the Theban area. Despite the overall simplification of the period, sometimes small details are added, such as a clump of lotus flowers over the head in pBerlin P. $3149^{71}$.

Inside this group the objects depicted are always protected (never offered) and follow the usual designs. As a rule, the eye represented is the feathered one with or without pupil and inside an oval. At times the simplified version (pVienna Vindob Aeg. 65) and the simple eye inside one oval (pParis Louvre N. 3081 -fig. 14-) also appear.

There are not many variations in the general scheme of composition; the two figures are almost identical in physiognomy and attitude and the objects protected come in pairs (two simple eyes -fig. 14-, two lakes, two shenrings). Two are the exceptions to this pattern. The first one is attested in pVienna ÄS 3862+ 10159 (fig. 15), with the depiction of a feathered eye inside an oval and a sizeable pool that rests over the ground on one of its large sides while the hands of the figure lay over it. The second exception shows up in pVienna Vindob. Aeg. 10.110, where the same change is introduced between a quadrangular pool touching the ground with one of its short sides and another object scarcely recognizable. A remarkable detail appears in this second papyrus: from the stem held by one individual hangs an object in the shape of a heb-sed pavilion, that conveys the same notion of endless time that is indicated by the stem.

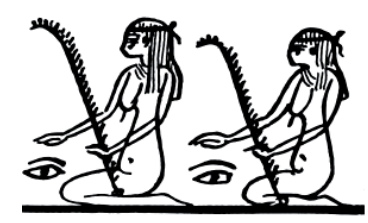

Figure 14. pLouvre I 3081, Ptolemaic Period, Memphite tradition; from Barguet 2000: frieze of vignettes over pages 57-60.

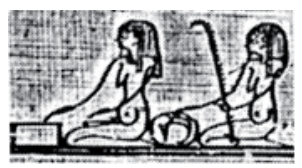

Figure 15. pVienna ÄS $3862+10159,249$ BC, Ptolemaic Period, Memphite tradition; from Satzinger 1994: Abb. 20 c.

The developing characteristics of the Theban tradition regarding the identification of places of production is also true of the Memphite area; papyri Vienna Vindob. Aeg. 65 and Paris Louvre N 3081 show formal similarities, although their owners are not related by titulature, despite their chronological closeness. pCairo CG. 40029, pParis Louvre N. 5450 and pVienna ÄS 3862+ 10159 also bear a compositional (not stylistic) likeness, but the fact that the last one is the only document where the whole image is preserved, prevents us from reaching further conclusions.

71. The Theban papyrus pFrankfurt SUB 1 shows the same plant headdress. In spite of the place of origin of this document, its general style with the lake resting over the groundline and a sizeable oval, is closer to the Memphite patterns as in pViena ÄS 3862+ 10159 (fig. 15), than to the Southern ones. 


\section{Akhmin}

In the workshops of Akhmin manuscripts were produced following Theban and Memphite patterns, but the funerary tradition is here reinvigorated by the introduction of new content and forms (demotic, retrograde script, variations in vignettes) ${ }^{72}$. The main feature of Akhmin's documents is the preeminence of feminine characters against fecundity figures, which are however depicted in an example at New Brunswick (fig. 17) and a papyrus whose inclusion in this tradition remains doubtful ${ }^{73}$. Women wear tight dresses that partially hide their breasts, except in pLondon BM 10479 (fig. 16). Although in this document both figures show a feminine (slim) physiognomy, their breasts protrude and hang as in the case of masculine fecundity figures, and are even highlighted by means of horizontal lines.

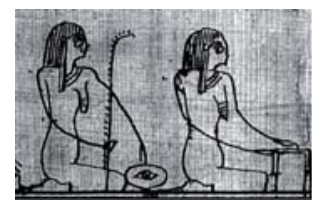

Figure 16. pLondon BM 10479, Ptolemaic Period, tradition of Akhmin; from Mosher 2001: pl. 3 = pl. 21, 1 .

Another novelty is the orientation of the figures, for in contrast to the Theban and Memphite traditions, where the characters look towards the left, in Akhmin they are directed to [50 ] the right. The exception to this rule is pNew Brunswick, that as we will note below, shows enough peculiarities of its own inside this

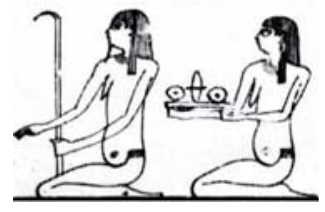

Figure 17. pNew Brunswick, Ptolemaic Period, tradition of Akhmin; from Clère 1987: pl. IV.

group. As in the rest of Ptolemaic sources, kneeling postures are dominant, and the common composition combines one figure stretching both arms to the front, while the other repeats the gesture but holds in one hand an object (a stem with one or several notches).

An outstanding variation to the compositional pattern followed since the NK is introduced in pBerlin P. 10477. Here the figures are not arranged in a row one next to the other, but are placed instead in two different registers, one over the other. The superposition of scenes inside the same frieze of vignettes is a peculiar trait of this document, but in other Theban Ptolemaic sources where the same artifice is used in many images, the two individuals embodying the Heracleopolitan lakes follow the usual alignment (pTurin 1833 and pMünchen Mon. Script. Hierogl. 1).

The common attitude in sources from Akhmin is the protective one, but the palms of the figures are usually in contact with the surface of the objects, which also undergo changes (fig. 16). As regards the lake on the one hand, in three documents it takes on a shape closer to a cube than to a rectangle and rests on the ground over one of its short sides, so that it resembles an

72. Quirke, 1999 a: 97 . Mosher thinks that the documents from Akhmin stem from a common source, but not from the same master copy. After comparing them with the Theban and Memphite traditions, he concludes that both texts and vignettes are often corrupted (2001: 14, 21-27). According to him, two manuscripts from Akhmin (pLondon BM 10479 -fig. 16- and pMacGregor) were the result of a serial production instead of being prepared ex profeso for a private person; to the text and vignettes were later added the name and titles of the purchaser in spaces left blank for the purpose (id.: 2, 4, 14, 22). Against other sources in this tradition, in which the vignette of chapter 17 of the BD covers $10 \%$ of the frieze of images, in pFrankfurt 1652c it spreads over $80 \%$ of the upper margin, but the image of the lakes has not been preserved.

73. pParis Louvre E. 11078, for which see n. 47 in table VIII. 
offering table. The reinterpretation of pools as pieces of sacred furniture was introduced during the last native dynasties and appeared again in certain Memphite examples (fig. 15). Concerning the eyes on the other hand, we remark a preference for the simple and simplified versions, against the feathered type, and the use of empty circles (a variant of the formers?).

Within this area of production, pNew Brunswick stands out for its use of fecundity figures, the change in the common attitude and in the object that complements the new gesture (fig. 17). The second figure performs the act of offering we had already met, although he presents no lake or eye but a tray loaded with food (elongated and rounded bread cakes), that convey the idea of nourishment and plenty. It is in fact one of the most common motifs in processions of offering bearers in scenes from tombs and temples, some of which can take on the appearance of fecundity figures. However, the food tray is an element alien to the text of our spell and to the image of the lakes in the rest of sources.

\section{Middle Egypt}

For this last tradition stemming from Middle Egypt there is only one source identified, pChicago OIM 10486, dated between 200 BC and the Roman Period (fig. 18). This document departs greatly from the patterns established at Thebes, Memphis and Akhmin in the type of figure, attitude, and object held ${ }^{74}$. First, the characters are males bearing no distinctive mark of status. Second, they unfold their arms towards the front as other figures, but as the elbows are bent in an artificial angle the act depicted is that of hugging, encircling or holding ${ }^{75}$. Third, this tradition dispenses with the central focus of the funerary passage, the lakes. Instead, two chapels have been included for the first time in our sources (taking the place of the former? ${ }^{76}$ ). Moreover, the object depicted between the two figures bears no resemblance to any real or imaginary element. It consists of a simple eye inside an oval, behind which projects vertically a stick similar to a mooring post. Its left upper end curves toward the inside while from the right side protrudes an oblique appendix, that looks like the knife included in the sign šmsw (牥).

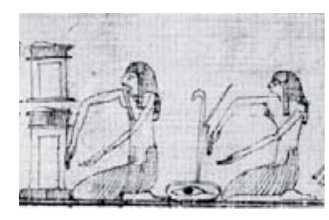

Figure 18. pChicago OIM 10486 (pMilbank), Ptolemaic Period, tradition of Middle Egypt; from Allen (1960): pl. 60.

Since none of the papyri recovered and analyzed heretofore share these peculiarities, we may suggests that pChicago OIM 10486 is either a corrupt copy from a master executed in Theban or Memphite workshops or, more likely, the prime example of a new local tradition (somewhere in Middle Egypt) with a character of its own.

\section{Unknown provenance}

Under this epigraph we include papyri heterogeneous in composition, style, finish and details, but which have in common that their

74. The exceptional nature of this document owing to its texts (trimmed and arranged with no clear order) and images (bearing unique features) has been highlighted by Allen (1960: 39-60). Also by Mosher, who however, observes similarities between it and documents of his style 3, which is based on Memphite sources (1990: 116, 460). Somewhere else he focusses on the resemblance of the vignettes in this papyrus (as regards style and sequential order) with the unpublished pNew York MMA 35.9.21 coming also from Middle Egypt (Meir) and dated to 250 - 200 BC (id., 462-463, 507). See n. 48 and 49 in table IX.

75. Wilkinson, 1992: 50-51.

76. See n. 49 in table IX 
place of origin is unknown. In the light of this disadvantage and the fragmentary state of preservation of many sources, we will not search for shared traits. Working on the features defined for the above traditions, we will try to assign each to one of the known areas of production. If this is not possible, we will highlight the peculiarities that make it resist all comparisons.

$\neg$ pParis Louvre E. 3232 shows all the compositional and stylistic characteristics of the second Theban group, with a mixed pattern of offering an eye and protecting a lake. It could therefore be included in the Southern tradition $^{77}$.

- pChicago OIM 9787 is similar to the Theban pTurin 1831 in the physiognomy of the figures (rounded and fleshy bodies shaped in colours), the general sequence of the vignette and even in the arrangement of the hieratic text. However, the differences are remarkable in the objects protected; while the former depicts two superimposed lakes, the latter has one single empty circle $^{78}$.

- pParis Louvre N. 3153 and pTurin 1834 show two fecundity figures of ambiguous sex (pendent breasts, but bellies scarcelly prominent and narrow waists, lack of kilts and belts emphasizing fatness), protecting two feathered eyes without ovals. The general physiognomy and these two elements are likewise found in the Theban pLondon BM $10037^{79}$.

$\neg$ pParis Louvre 3100 revives the tradition of colourful vignettes, fleshy and scantily de- tailed figures and hieroglyph texts arranged in columns separated by vertical lines, which are found in certain Theban documents from the Ptolemaic Period (pAberdeen ABDUA 84023.4, pBerlin 3158 A-G, pParis BN 1/19 and pTurin 1831, even though the text was recorded in hieratic in the last) or earlier (as in pParis Louvre N. 3094, dated between Late and Ptolemaic Period, with which it shares the suppression of all elements being protected).

- pTurin 1835 conveys two identical objects being protected: two small pools. Although the dual nature of these had been abandoned by the Ptolemaic Period, this document has its formal parallel in the Memphite pLeiden T17. However, the stylistic differences among them are great enough to dismiss the idea of a common workshop.

$\neg$ pCairo JE 95859 and pMainz Gutenberg Museum HS 22 exhibit a reinterpretation of the lakes as low altars similar to the one attested in the Ptolemaic traditions of Memphis and Akhmin and that had appeared in the previous period. In the first document, the two protected objects, the pool in almost cubelike shape and resting on the ground over one of its short ends, as well as the sizeable eye inside an oval echo some of the Memphite patterns (such as pVienna $3862+10159$ ), though there are stylistic differences between them. In the second one, the lake adopts the shape of a table or quadrangular altar with a protruding border and the figure rests his hands directly on its surface. We have come across this type of composition at Akhmin, but contrary to this tradition, the papyrus clearly portrays mascu-

77. Mosher shows the similarities between the vignettes in this manuscript and those in the Theban pParis Louvre 3152 , which could owe to their common origin in a Theban source (1990: 453).

78. Mosher accepts Allen's suggestion that the papyrus from Chicago comes from Edfu, but suggests that it was executed after a Theban master copy. He finds support for his hypothesis in its similiarity to other documents from the Theban area as pParis Louvre 3089, 3129 and 3248 (id., 455-456). pChicago OIM 9787 also shares with Theban pTurin 1791 many features and certain unique details which lead Mosher to propose a common source for both (id., 457-458).

79. The document in Turin has in common with this Theban papyrus the arrangement of the text in columns of homogeneous size. As regards the papyrus from Paris, Mosher includes it in his style 1b (1992: 148-149) and suggests for it a Theban origin in the light of the titles born by the owner (1990: 456). 
line characters and the scene is orientated in the opposite direction.

The remaining sources mentioned below bear traits foreign to all the centres of production examined thus far and could be taken with certain reservations as representative of new traditions.

- The style of pLondon BM10844 shows many peculiarities: the vignettes are not always finished, traces of guide lines are still visible and some figures either make faces or are distorted as if caricatures ${ }^{80}$. In our scene, the characters are male, bear no distinctive mark, and are depicted in different attitudes to those reviewed (protection, offering, embrace); they hold a branch in one hand and point the other with its fist clenched to the front. No object has been depicted in the latter hand to help us define which action was performed.

- The case of pAngers MTC 747 is also uncommon; only one character is preserved that grasps two objects in his hands (a stem with notches and an ankh-sign) and no eye, pool or door is depicted nearby.

- A scheme far from the "canonical patterns" appears in pBerlin P. 3003, where the two figures are not aligned or set one beside the other. Instead they are juxtaposed or arranged one over the other in the same resgister, so that only the profile of the second one is visible. Again, any object complementing the act of protecting has been suppressed.

- In pParis BN 141-148 a scheme is resumed that had characterised the earlier stages of the vignette: one figure stands while the other kneels. The first one is a male, wears a divine beard and protects under his arms stretched in opposite directions a lake and an opened door. The second one is a fecundity figure and covers with only one arm a feathered eye. The combination of three different objects is exceptional, because doors are usually inserted instead of lakes, not beside them.

Finally, several manuscripts show empty circles as objects offered or protected. In pOslo "Lieblein Papyrus" both individuals are outlined in a schematic way and offer over the palms of their hands these two elements. Meanwhile, in pZagreb 600 these are represented under the protection of their hands. Empty circles are included in pAberdeen ABDUA 84023, 1-7 from Thebes. However, the style of the first two papyri, with shapes executed in outline contrasts heavily with the two plump and colourful figures of the Theban example.

\section{The Heracleopolitan Lakes on Mummy BANDAGES}

We conclude the analysis of the image of the Heracleopolitan lakes in chapter 17 of the BD remarking that between the 26th Dynasty and the Graeco-Roman Period there is a flourishing production of BD copies on mummy linens. The extremely fragmentary state of these documents increases the number of sources in which only a part of our vignette has been preserved, but could nonetheless have originally included the image of the pools ${ }^{81}$. An scrutiny of these documents is rendered more difficult due to the delay and scarcity of publications. The fact that many are located in private collections and are a priori regarded as less attractive than papyri seems to have limited their publication. Other disadvantage stems from the peculiarities of the material,

80. Quirke, 1999 a: 91, suggests that the document was originally intended as a master copy for a library.

81. Thirty-six mummy bandages without the lake scene against twelve where it is preserved. In two of them, the image has been shortened, omitting the pools: M. Brüssel E. 6179, $n^{c}-n-f-b 3 s t t$, 26th Dynasty, De Caluwe, 1991: pl. VI A-B, VII A-C; M. Sydney R. 87 (f), p3-si-t (i) or $p 3$-di- $h r$, Ptolemaic Period, Coenen, 2006: 85-86, Taf. 16g, extra sources: M. Berlin without number, M. Marseille Inv. $5589+5590$. 
which produces more schematic and less detailed compositions, as compared to papyri and tomb decorations. The identification of characters and objects is thus often more difficult (fig. 19). Finally, distinguishing among traditions or workshops is even more complex owing to the wider variety of sites of discovery (Gurob, Saqqara, Heracleopolis Magna) and to the fact that the provenance of many bandages is unknown.

Male fecundity figures are dominant and they are always depicted kneeling and looking towards the left. They carry a stripped branch or more frequently one with notches. Inside this pattern, the placing of the arms in $\mathrm{M}$. Aberdeen ABDUA $23552+56040+56041 \ldots$ is unusual, since the elbows are bent in a very acute angle and the objects held are raised obliquely over the ground. Despite the general decrease in details, sometimes headdresses are included (a lace holding the hair or a clump of papyri over the head). The protective attitude predominates, except for one document where one figure offers a feathered eye, while the other protects an empty oval. This scheme vaguely echoes the second pattern we had identified in the Theban tradition of the Ptolemaic Period.

The range of protected objects is broader at both composition and individual level. As to the first, there are paired schemes with two elements that can be identical -two empty circles in M. Los Angeles 83. AI. 47. 1. 4 and M. Vienna ÄS 3848; two ovals possibly encircling a simplified eye in M. Simonian Private Collection- or different. As to the second, the addition of detail gives rise to new variants in depicting eyes: thick eyelashes, eyebrows and vertical strokes. The pools seem to have lost their prevalence, though this finding may be influenced by the state of preservation of the sources; in several manuscripts one of the elements has disappeared and only the protected eye remains.
The decoration of mummy linen could have been undertaken in the same workshops that produced papyri. The two following examples

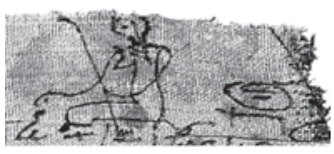

Figure 19. M.Aberdeen ABDUA 23552; from Curtis; Kockelman; Munro 2005: fig. 8.

may be illuminating. First of all, M. Aberdeen ABDUA 84041.1 and M. Paris Louvre N 3138 +3058 , with one feathered eye inside an oval and a sizeable lake resting over the ground on its large side as protected objects, share similarities with the Memphite pattern attested in pCairo CG. 40029, pParis Louvre N. 5450 and pVienna ÄS $3862+10159$ (fig. 15), although only the latter is wholly preserved. Second, in M. Los Angeles 83. AI. 47. 1. 4 the lake has been turned into a pedestal, table or offering altar crown by a cyma. This image is reminiscent of the patterns at Akhmin, but the figures in the bandage are orientated in the opposite direction to the characters in papyri of the Southern tradition.

\section{The Interpretation OF the Heracleopolttan Lakes in Vignette of Chapter 17 of the Bd}

At this stage we may attempt to disentangle the symbolism behind the elements (in themselves and as a whole) in the scene of the Heracleopolitan lakes and analyze the modifications (temporal and/or local) undergone, considering whether they entail changes in meaning ${ }^{82}$. We must bear in mind that the content of the passage, centred around the purifying and revitalizing cleansing of the deceased in the pools, is not subject to great

82. We follow Mosher's suggestion stemming from his analysis of LP vignettes: "these new and revised vignettes were often based on specific passages in the spells, and often on subtle interpretations of the text in the respective passages" (1990: 438). 
variations in the course of its transmission -except for small changes in verbal forms.

From the numerical data can be inferred an astonishing and steady increase in the use of vignettes decorating chapter $17^{83}$. For the period between the NK and the TIP the number of known papyri containing the chapter in its written, pictorial or mixed (text and vignette) form amounts to one hundred and thirtyfive. Somewhat fewer than a fifth of the total (twenty-five papyri) included the developed frieze and of these, six documents convey the abridged version of the vignette that omits the Heracleopolitan lakes ${ }^{84}$. Thus, the pools are depicted in nineteen documents altogether.

To contrast the information provided by papyri we can turn to those Ramesside royal and private tombs of the Theban necropolis which included our spell on their walls or funerary objects. From thirty-three known sources, only seven show the scene of the pools, while in the remainder the selection of images resulted in the omission of the lakes. If we assume that those motifs of chapter 17 which are more frequently depicted are those regarded as more significant or representative of the whole text (thus, the scenes of the senet, Ruti, Miu with Apep ${ }^{85}$ ), our subject of study could not be deemed as being of central importance. Ex- pressed differently, it may not have been one of the main features of the formula.

During the LP a review of all vignettes, with the exception of those linked with transformation spells, is accomplished. A certain "canonization" or "standardization" of friezes takes place, as a result of which, the scenes are turned into a sort of abridged substitute for the text itself and an ideal alternative for people only capable of affording a limited length of papyrus ${ }^{86}$. The style of images begins to be homogenized inside the same area of production, so that in the Ptolemaic Period reference can be made to the workshops in Thebes, Memphis, Akhmin ...

The data for the period between the 26th and 30th Dynasties are as follows: eleven documents bear the image of the lakes; in eight papyri it might have been included, but this particular section of the frieze is not preserved; in two instances it was omitted from the selection of scenes carried out ${ }^{87}$. As regards the Ptolemaic Period, sixty-eight papyri, nearly the half of which stem from Theban workshops, and twelve mummy bandages include our image. In another twenty-eight examples of the former and thirty-three of the latter it could have been inserted but it is not preserved and ten documents with shortened friezes omit it ${ }^{88}$. The increase of sources is remarkable if we bear in

83. The numerical information on chapter 17 of the $\mathrm{BD}$ was kindly provided by the personnel in the Totenbuch-Projekt; all papyri were personally checked in Bonn in November 2006.

84. See n. 44 for NK examples and n. 59 for TIP ones.

85. Saleh, 1984: 14-16, 19-section IV-for a list of Ramesside tombs bearing chapter 17 of the BD (TT 32 is not included here).

86. Mosher, 1992: 144; id: :2001: 12-13. In pParis Louvre N. 3100 only the vignette, and not the text, of chapter 17 of the BD has been included (id.: 12, n. 48). The author states that the text is also omitted in some sources that convey the shortened version of the vignette (id.: 159, n. 68).

87. 1: pBerlin P. 3161 A+B, p3i-fiwiw, Kaplony-Heckel, 1986: Nr. 66; Verhoeven, 1998: 222-223; 2: M.Brussels E. 6179, $n^{\top}-n-f-b 3 s t t$, Caluwe, 1991: pl. VI, VII.

88. 1: pTurin 1792, $p 3-d i-h r-p 3-h r d$, 30th Dynasty- early Ptolemaic Period, [Thebes], Seeber, 1976: 226, n. 75, Bellion, 1987: 276; 2: pVatican 38598 = Vatican 57, irt-hrw-r-w, early Ptolemaic Period, [Thebes], Bellion, 1987: 319; Gasse, 1993: Nr. 54, 65-66, pl. 43-44; 3: pLondon BM 10033, p3-iw-n-hrw, Thebes, Quirke, 1993: 56 (186); 4 : pIstambul 10846-10847, [Thebes]; 5: pTurin 1793, 3st-m-3h-bit, [Thebes], Seeber, 1976: 226 (76); Bellion, 1987: 276; 6: pHildesheim 5248, $d d-h r$, called wsir-wr, Akhmin, Mosher, 2001: 65-66; 7: pYverdon, $n s-\varsigma ̌ w, ~ A k h m i n$, www.pmimage.ch/scypverdon.htm; Küffer, 2006; 8: pParis BN 118-127, ns-mnw, early Ptolemaic Period, unknown provenance, Bellion, 1987: 76; 9: M. Sydney R 87 (f), $p 3-d i-t$ or $p 3-d i-h r$, extra sources: M. Berlin without number, M. Marseille Inv. 5589 + 5590; Coenen, 2006: 85-86, pl. 16g; 10: Tomb of p3-di-b3stt, Dakhla Oasis (Qaret el-Muzawwaq), 1st century BC, Osing, 1982: 71-81, Taf. 21-24, 31. 
mind that of a total of one hundred and thirtyfive papyri of the NK and TIP only nineteen $(6,7 \%)$ introduce the scene of the pools, while of one hundred and seventy documents of the Late and Graeco-Roman Periods, the number rises to one hundred and fifteen $(71,9 \%)^{89}$.

In a comparative analysis of the lakes' representation $^{90}$, it is significant that in the NK the vignettes are more carefully executed and colourful and show a wide variety of composition (figs. 4-7). In the period of the Saite Recension, despite the standardization that takes place, there remains a certain variability in the friezes of images, while important innovations are slowly introduced and will consolidate in the course of time (figs. 9 and 10). In the Ptolemaic Period the growth in the number of sources leads to a greater range in form, style and execution (figs. 11-17). Two trends are in progress then: a decrease in polychrome manuscripts in favour of outlined and monochrome (black) compositions; a reduction of details, which affects the figures in their anatomy (many are shown in profile), body posture (always kneeling) and ornaments.

The most characteristic element of the scene is the presence of two figures performing specific acts over certain objects, usually over pools, and feathered eyes. In a limited number of instances and from the 21st Dynasty on, this pair can be fused in one single character, perhaps owing to the trend towards abridging vignettes which begins in the TIP. They are in most cases male fecundity figures, that represent the notions of abundance, maturity, and non-sexual fertility. Gods closely linked with water, such as Nun and Hapy, used to adopt their physiognomy ${ }^{91}$. Three are the most remarkable exceptions: papyri from the 21st Dynasty featuring simple males with or without divine attributes (fig. 8); Ptolemaic productions from Akhmin -and in some cases from Memphis- with their choice of women (already introduced with the last native dynasties, figs. 14 and 16); ambiguous instances where the sexual distinction is not clear. It is noticeable that no hierarchy is established between the two figures, for they are drawn at the same scale. Except for the tomb of Amenemeses, both cover a similar space (in height), despite the fact that one is depicted standing whilst the other squats.

Two body postures are favoured: standing and kneeling. In early documents both are combined, but since the 26th Dynasty there is a preference for kneeling figures and the orientation towards the left of all elements in the scene. Both attitudes are more static than dynamic. In the first place, standing characters are not walking, since neither are their legs widely stretched nor are their knees bent. Second, kneeling individuals are not shown with flexing insteps, but are rather shown resting on the ground with their feet and knees ${ }^{92}$.

89. The entire corpus of papyri (figures supplied by the Totenbuch-Projekt team in Bonn) includes the following types: written, pictorial, mixed. To calculate the percentages of papyri bearing the image of the pools, we have taken into account also those documents that owing to carefulness in the execution of friezes, might have included the scene though it has not been preserved (see Appendix I for details).

90. We owe the only partial analysis of this image to Milde (1991, see section VII in the description of vignette of chapter 17 of the BD) and Mosher (1990: 172-174, 642, under the sigla A8a and A8b).

91. Baines, 1985: 116, 122. There is a striking relationship between the notions transmitted by the Heracleopolitan lakes, Nun and the fecundity figures of our vignette. It is significant that the earliest personification of $w 3 d-w r$ (which is also the name assigned to one of the local lakes) in the royal funerary temples of the OK, adopts the form of a fecundity figure, as our image of the pool does. Moreover, the watery nature of $w 3 \underline{d}-w r$ can be represented by means of horizontal zig-zagging black lines and the use of blue tones (Diego Espinel, 2006: 91, n. 440 and 441), two traits also attested in our papyri (fig. 4).

92. Two exceptions are known, where a fecundity figure and a male character with divine beard respectively have their knee raised (but still remain in a static position), as in the attitude represented by the sign ${ }^{2}$ : pLeiden T2 (19th Dynasty) and pLondon BM 10554 (21st Dynasty -fig. 8-). 
The identification of these main characters is possible thanks to those documents in which their names are registered. Since these are the same as the ones assigned by the glosses of spell 335 of the $\mathrm{CT}$ and chapter 17 of the BD to the Heracleopolitan lakes, we can take the figures as personifications of the elements they are themselves protecting ${ }^{93}$. Moreover, the re-editions from the NK on of the funerary spell dated to the FIP / MK add after the name of the pools the determinative of a god - 용. We regard this fact as an indication of the new status endowed to the lakes: embodied and represented as divine entities.

The identification can be extended to the rest of the sources. Not only is the iconography similar in all of them, but there is a close relationship of the characters both with the lakes they protect and with the primeval water of these pools ${ }^{94}$. Their bodies are painted often in more symbolic than naturalistic colours (blueish and greenish) or are sometimes covered with waves. There is a linkage between the tones used and the concepts that the fecundity figures themselves embody as personifications of the Heracleopolitan lakes: water (and flood), fertility, renewal, life and rebirth ${ }^{95}$. The rich chromatism can be used also in the wigs of men and women and even in the dresses of female characters, but is discarded in papyri of the Ptolemaic Period that display a preference for vignettes executed in black outline.
In general, many figures show some type of ornament, whether necklaces, bracelets or anklets. Headdresses over wigs are scanty and only stems tied around the head, and clumps of papyri and lotuses are otherwise attested. While the first ones are linked with the god Heh, the second are a usual attribute of fecundity figures as symbols of abundance and life.

The favourite action made by the characters in the early examples is the protection of two elements under the palms of their hands (figs. 4-9, for later examples see figs. 11, 14-16, 19). This counts among the less frequent attitudes connected with fecundity figures, which are usually portrayed instead as bearing or presenting offerings, uniting the two lands ( $s m 3-t 3 w y)$ or libating. Among these figures, the protective gesture is only attested in funerary contexts ${ }^{96}$, similar to that of our scene. It can be made by other divine beings outside these fecundity symbols ${ }^{97}$.

From the late Dynastic Period on (30th Dynasty -early Ptolemaic Period) the hands are depicted in a different position; directed towards the top and with objects placed above, the act is no longer that of protecting but of offering (figs. 10, 12, 13, 17) ${ }^{98}$. The new reading to which the scene is subject is noticeable in pNew Brunswick (fig. 17); lakes and eyes are suppressed and the second figure offers a reed

93. The idea was already put forward by Seeber, 1976: 66 and Baines, 1985: 382 .

94. The water in temple lakes flows by capillary attraction from the water table and is therefore connected with the Nun. As the primeval element in Egyptian cosmogonies, the Nun helps the sun and the deceased in the transit to rebirth. The resurrection is precisely the aim of the latter when he/she bathes in the Heracleopolitan lakes (this idea was already suggested by Bonnet, $R \ddot{A} R G: 228$ and Geßler-Löhr, 1983: 222).

95. We suggest that the election of fecundity figures is explained by the relationship of these characters and the lakes with the idea of renewal, and not by the linkage of the local pools to the place of birth of Osiris, as held by Mosher, 1990: 172-173.

96. Baines, 1985: 326, thinks that they are static gestures, perhaps derived from symmetrical compositions. We have seen above that the postures of our characters are also more static than dynamic.

97. Desroches-Noblecourt, (coord.), 1976: 195, 197, regarding the funerary chapel of Khnosu -JE 27302- points out that both the gods depicted on the short ends and the four Sons of Horus on the long sides direct the palms of their hands towards the floor in a protecting attitude.

98. Baines distinguishes between the acts of presenting (offering) and bringing offerings, remarking that the former is regarded as more prestigious than the latter and is usually referred to as $r d t r n p t ; m s$ (1985: 317, 323-324). The other two gestures attested in Graeco-Roman sources (embrace and clutch) could be taken as isolated cases, probably due to local variants of the most common arrangements. 
mat piled with food ${ }^{99}$. A reinterpretation of the scene occurs, in which priority is given to the most characteristic function of fecundity figures (offering ${ }^{100}$ ) against the mythologeme of purification of the deceased with water. However, the latter remains the climax of the episode centered around the Heracleopolitan lakes, as the text of chapter 17 of the BD shows. This change entails not only a modification in the attitude of the figures, but also in the meaning of the image. A modification that nevertheless does not catch on; of all documents dated between the 26th Dynasty and the Ptolemaic Period, only $15 \%$ choose to represent the offering gesture instead of the protecting one.

The objects that complement these actions show a varied typology. The most frequently depicted are lakes and eyes, but already in NK sources we also find doors. As time goes by new elements are introduced, which can be regarded as unique cases if they are only recorded in one manuscript: a heb-bowl, a shen-ring, a mooring-post... From the LP on are attested instances in which all symbols of purification and renewal have been suppressed, although their remembrance endures in the protecting or offering gesture performed by one of the fecundity figures when his hand hovers above or below an empty space.

There are two bodies of water mentioned in the funerary passage of $\mathrm{CT}$ and $\mathrm{BD}$ and the dual nature is a hallmark of the early examples of the vignette dated to the NK and 21st Dynasty ${ }^{101}$.
The Heraclopolitan lakes are endowed with the capacity of making more effective the rebirth of the deceased. This regenerative power stems from their origin (as they flow from the water table they are linked with the Nun) and the mythological context (the presence of the sun god in the city). In polychrome papyri they tend to be filled with blueish tones (as in pLondon BM 10470 -fig. 4-), that are reminiscent of the liquid contained in the pools. However, in pColonia Aeg. 10207 (fig. 9) yellow is used, in pLeiden T2 a colour between yellow and green and in pTheben / Ramesseum green. Taken together, these colours are symbols of the godlike power and capacity of renewal of the lakes. Moreover, the ideas of eternity and life transmitted by the main characters and the pools are reinforced by other elements in the scene: renpet-branches and ankh-signs held by the figures and objects such as shen-rings (which can at times take the place of lakes and eyes).

From the 26th Dynasty onwards, when texts and vignettes are reviewed, the importance of the lakes seems to have diminished and their characteristic duality is lost, although they still remain a highly significant element in the formula. At times, only one lake is drawn, and others a reinterpretation of this element results in a change of shape and meaning. Whether it keeps its rectangular form and rests over the ground on its long side ${ }^{102}$, or whether it is turned into a cube lying on the ground in its short side ${ }^{103}$, it is closer to a piece of sacred furniture, such as a low altar

99. Mosher, 2001: 14 and 22, stresses that some vignettes and certain passages of text in pNew Brunswick do not follow the Theban and Memphite standardized versions, and suggests that they derive from a corrupted original, in which different images were randomly mixed.

100. For acts of bringing and presenting offerings performed by fecundity figures see Baines, 1985: 209-225, 317-325.

101. There are four exceptions to this duality: 1-pLondon BM 9949 in which two doors are shown (in substitution for the two pools? -fig. 6-); 2 and 3-in the Ramesside tomb of Anhurmose (fig. 7) and in pColonia Aeg. 10207 (fig. 9) dated to the 26th Dynasty three lakes have been depicted. In this respect, it is remarkable that in pTurin 8438 the logogram of a pond with birds is exceptionally written down three times (see pT1 in Lapp's edition, 2006: 76-77); 4 - in pCologny $\mathrm{C}$ from the 21st Dynasty the scene has been merged as one figure protecting a single lake.

102. The variant appears in these Ptolemaic documents: pFrankfurt SUB 1 from Thebes (but of Memphite style); $p$ Vienna ÄS $3862+10159$ (fig. 15) from Memphis; M. Paris Louve N. $3138+3058$, of unknown provenance.

103. In sources from the last native dynasties and early Ptolemaic Period: $p$ Vatican $\mathrm{N}^{\circ}$ Inv. 48.832 and pNew York MMA 35.9.20. From the Ptolemaic Period: pMacGregor, pLondon BM 10479 (fig. 16), and pBerlin 10477 from Akhmin; pVienna Windob Aeg. 10.110 from Memphis; pCairo JE 95859, pMainz HS22 and M. Los Angeles 83.AI.47.1.4, all of unknown provenance. 
or offering table, than to a basin. Similar objects appear in scenes of purification and libation from the $\mathrm{OK}$ on ${ }^{104}$ and are common in tomb's decoration (fig. 20) ${ }^{105}$. The convergence of lakes and offering tables is understandable (and even convenient) since both are useful for the continuation of life after death. In fact, the latter usually have on their surfaces basins carved in the shape of pools. Offereing tables and lakes are

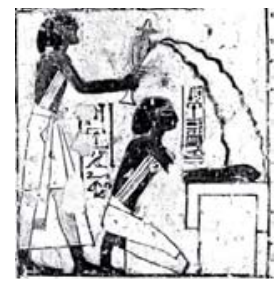

Figure 20. Scene of purification performed by priests over a low altar decorating a tomb; from Hofmann et al. 1995: Abb. 39.

sometimes even depicted together in the same source (as in pVatican $\mathrm{N}^{\mathrm{o}}$ Inv. 48.832 and $\mathrm{pNew}$ York MMA 35.9.20). Moreover, pools and offering tables are devices that revolve around water for the regeneration of the dead. On the one hand and according to the funerary texts translated, cleansing in the local basins entailed casting away the evil of the deceased, in an act that was equated both with the new birth and the purification of a breast-fed baby. On the other hand, libations poured over offering tables were aimed at the symbolic sustenance of the dead. Not only did they animate the food depicted on their surface, but they acted as a simulacrum of the annual flood and the beginning of the cycle of vegetation as well. They also served as reminder of the funerary state, since they were metaphors of the garden and funerary store of the deceased and were assimilated to the cultivated areas of the next world ${ }^{106}$.

We have mentioned several times that doors seem to be used instead of lakes in some documents, specially in those belonging to the Theban Ptolemaic tradition. In these, the dual nature of the pools is kept for the gates in a majority of sources ${ }^{107}$, and the leaves are usually displayed opened, showing that the way is free for the deceased or the god in the Beyond. Doors and portals are regarded in funerary Egyptian texts either as physical or symbolic thresholds or as insurmountable barriers, and could be therefore be linked with ideas of transition or of protection. As indicators of the passage between two states of being they are similar to the Heracleopolitan lakes, the main role of which is to allow the deceased to resurrect and then continue his/ her way identified with the sun $\operatorname{god}^{108}$.

As regards the eye, it is the other characteristic element in the scene and can appear in a wide

104. Compare the scene in pLondon BM 10479 (fig. 16) with the images published by Gardiner, where purification scenes are accompanied by the caption $w \underline{d} b$ iht , "reversion of offerings" (1938: pls. V and VI. 2) and with images of cleansing in several tombs (fig. 20). They are part of the preliminary acts before the offering usually showing one priest kneeling before a low altar while another poures water (sti $)$. They are integrated in a ritual intended for the purification of both the celebrant and the hands of the deceased before consuming the food (Aufrère et al., 1992: $33 \S 58)$.

105. Offering tables summarize a funerary mechanism based on nourishment. They convey the idea of the tomb's courtyard, where the stela of the deceased is erected (Aufrère et al., 1992: $21 \S 16$ ), and remind him/her of the joyful moments spent in the gardens, the freshness that surrounds outdoor meals, the return of [new] water with every flood and fishing and fowling in marshes (ead: : 58-60 § 116, 119, 123-125).

106. ead.: $62 \S 129,65-66 \S 140$. Examples of votive basins in T-shape, where libations took place as a means of remembering the flood and of assisting the rebirth of the dead in Desroches-Noblecourt, 1991: 75-79.

107. Instances depicting a single door are also attested in the Ptolemaic Period (e.g. pParis Louvre N. 3149, 3204 B, 3123 bis +3213 ), but the lakes have by then also lost their dual character. pParis BN 141-148 seems to be an isolated case, since the door does not appear in place of the lake, but beside it.

108. The meaning of doors in iconography has been analyzed by Wilkinson, 1992: 146-147. Nibley links the notion of purification with water and natron either with the change of state or divinization of the deceased, or with a rite of passage that prepares one to perform the religious acts $\left(2005^{2}: 136-139,145\right)$. 
range of types: the feathered eye (㞼), with or without cheek or pupil ( 5 ), dominates all documents from the NK and 21st Dynasty and is still predominant in the following periods, when new shapes are introduced; the wedjat ( plified in isolated cases from the Saite Period on; the simple-eye ( $\infty$ ) and the simplified version (a rough sketch $\Longrightarrow$ ), is evident in the same period and the former dominates in some of the Ptolemaic traditions, specially in Akhmin and Middle Egypt. Inside this typology, we suggest that the empty ovals and circles may in fact represent variants of the simplified eyes.

In the earlier sources the motif is usually inscribed inside an oval or circle, while since the beginning of the Greek dominance they are frequently suppressed, especially in Theban workshops. Until the 26th Dynasty, while the duality holds for the lakes, it is common to represent a single eye, except in compositions guided by an axis of symmetry (two opposite eyes in pLondon BM 9949 -fig. 6- and possibly also in pLeiden T4). From then on, the eye gains popularity, either combined with a lake, or less frequently, paired with another eye as the only elements depicted.

The feathered eye of Horus, inside an oval or not, is the most difficult element to interpret in the scene. Neither is its name recorded in any document, nor is the motif frequent in other contexts ${ }^{109}$. Moreover, the text connected with the vignettes of chapter 17 of the BD refers to several eyes with which it could be related. Many scholars consider it to be interchangeable with the wedjat, the symbolic substitute of every offering ${ }^{110}$ and a metaphor of the complete being, the divine order and the moon ${ }^{111}$. We reject this idea on the grounds of the typological differences between both of them, but we allow for a relationship with the solar aspect, which we will address below.

Baines suggests that the sign functions as a logogram for the word $i m 3 h w$, so that in the scene it represents the deceased who has been restored to life and is worthy of praise, i.e. the venerable ${ }^{112}$. Based on an image in the tomb of Bekamun of the 19th Dynasty, he states that the eye inside the oval is connected with the mummy represented in the upper register, because the latter reinforces the notion of resurrection conveyed by the former ${ }^{113}$.

In connection with the cosmogonic notions of creation from an egg, some Egyptologists suggest that the compound figure oval+eye represents the future being, the potential entity that will soon come to life ${ }^{114}$. Other researchers such as Seeber consider that the sign con-

[ 60 ] 111. The lunar linkage is suggested by Desroches-Noblecourt, (coord.), 1976: 204, but is at odds with the mythological context of the the spell, which describes the nightly trip of the sun god and the deceased identified with him. For the symbolism of the wedjat-eye see Wilkinson, 1992: 42-43.

112. Wb. I, 82, 2. Baines, 1985: 327. Of the same opinion is Van de Walle, 1985: 367.

113. Baines suggests that vignettes of chapter 17 of the $\mathrm{BD}$, with figures in static postures of protection, follow two patterns: the symmetric composition decorating the ceiling of this tomb and the iconography of an ointment container from the mid 18th Dynasty, published by Desroches-Noblecourt (1953). However, the action performed by the figure in this second source does not resemble that of our vignette; with one palm turned up (sic) he holds an inet-fish, a symbol of the gestating being or the mummified dead, while with the other directed towards the front he enacts what DesrochesNoblecourt describes as a gesture of protection, though it could well be an act of worship instead (ead., 6-9 and pl. I, A).

114. Desroches-Noblecourt, 1953: 8; Nibley, 20052: 145 and footnotes of figs. 40 and 69, states it is an wedjat-eye (which represents the deceased) in embryonic stage, since it is placed inside a placenta (!). It therefore symbolizes the acts preceding the beginning of organic life. We consider that his reconstruction of the birth process based on the vignette of chapter 17 of the BD though compelling, is not supported textually. 
veys the idea of the sun during two instances of outmost importance in its cycle: rise and set. She tries thus to reconcile on the one hand the topographical indications of a gloss in CT 335 , which locate the lakes in Iunu (equated with the eastern horizon) and Naref (=western horizon) ${ }^{115}$ and on the other, the illustration of papyrus London BM 9949, where two opposite eyes have been depicted and two doors take the place of the pools -fig. 6-. She points out that the pools in the gloss of CT 335 and the doors in this vignette of chapter 17 of the BD symbolize the whole solar course between dawn (=Iunu) and dusk (=Naref $\left.{ }^{116}\right)$. The two eyes inside the ovals would therefore stand for the places of departure and arrival of both the sun and the deceased willing to identify with it by describing the same journey ${ }^{117}$. Her hypothesis is compelling for its linkage with the notion of transition between two worlds that is attached to doors. However, in the documents that from the NK onwards pass on spell CT 335 , the gloss only attested in the coffin from Saqqara begins to fade ${ }^{118}$ and in most of the vignettes a single eye is depicted.

We do not dismiss the association of the feathered eye with the gestating or already reborn deceased, who is therefore praiseworthy.
However, we would like to suggest its identification with the sun-god in his manifestation as Re or Atum on the following grounds:

a| The word imakhu written with this type of eye as determinative can refer, as well as to the deceased (Baines' hypothesis), to deities like Atum, one of the manifestations of the sun god during dusk and night and in his role of creator ${ }^{119}$.

b| The sign eye+oval can be interpreted as a combination of two elements that are typical of the falconlike appearance of Re: the falcon's eye and the solar disc. This idea reinforces the previous one, since in fact, $R e$ is understood as a manifestation of Atum according to certain speculations of the $\mathrm{MK}^{120}$. The solar eye of Horus - which represents $\mathrm{Re}-$ symbolizes as well the concept of light or luminous energy, that is in keeping with the context of purification previous to the process of solar (re)birth and (re)creation latent in spell 335 of the $\mathrm{CT}$ and chapter 17 of the BD.

c| Our hypothesis also holds in those cases from the 26th Dynasty on in which other types of eyes -wedjat, simple- are

115. The gloss transmits the following information on the lakes: "it is the Lake of Natron, its name is Sea, it is the eastern shore in Iunu (Heliopolis); it is theLake of Maat, its name is Seed (or Germ or Father) of Millions, it is the western shore in Naref" -CT IV, 216 c; 219 c-g [335], only recorded in coffin Sq1Sq.

116. Naref could be considered as the spatial and mythological counterpart of Iunu. In the real world Helipolis is located in the eastern bank of the Nile, theologians associated it with the eastern horizon and dawn, while religious texts linked it with the place of creation of the world, the sun's (re)birth, and Osiris's embalmment and revivification. Conversely, Naref is placed in the western bank, somewhere to the north of Heracleopolis Magna, has connections with the western horizon and dusk, and was reputed as being the burial ground of a local manifestation of Osiris and one of the entrances to the other world.

117. Seeber, 1976: 65-66. A similar idea to Seeber's, but based on different concepts and later sources is proposed by Goebs, 1995: 172. The latter argues that the whole solar course, as symbolized by the $n m s$-representing the daily half of the cycle- and the $3 t f$ crowns -its nightly counterpart- is embodied in the figure of the local god Heryshef, himself a symbol of the syncretic union of Re and Osiris.

118. Exception made of the two earliest editions of chapter 17 of the BD quoted in $n .16$.

119. $\mathrm{Wb}$. I, 82, 17-20. It may be an objection to our hypothesis that the only examples quoted are from the Ptolemaic Period, but we can not reject the possibility of finding earlier examples as our own source. Baines' equation between feathered eye and imakhu is subject to the same problem, for the instances known go back only to the LP ( Wb. I, 82, 2).

120. Both differ in the role assigned to them. While Atum is the primeval, engendering energy, who does not take part in the maintenance of the world after creation, Re is the visible appearance of Atum after the cosmos is created and the guarantor of its continuity with his daily cycle (Shalomi-Hen, 2000: 14). 
introduced in the vignette of chapter 17 of the BD. The creator solar god could take on the appearance of an wedjat and in fact the latter functions as determinative of one of the names of the sun god in the Litany of $\mathrm{Re}^{121}$. His (solar) eye could even be represented as a simple eye ${ }^{12}$. Moreover, in funerary compositions centred around the nightly journey of the sun and depicted in royal tombs from the NK, this luminary adopts the image either of a simple eye inside an oval or of an wedjat (fig. 21) ${ }^{123}$. The TIP brings about an astonishing increase in funerary objects of Osirian and Solar symbols of resurrection. Among them, the feathered eye could be used to portray one of the forms of the sun during his nocturnal wanderings ${ }^{124}$.

d| Other details inside the vignette (platforms lifting the eyes, colours) reinforce our suggestion. In papyrus Leiden $\mathrm{T} 4$ from the 19th Dynasty, the eye has been raised over a decorated pedestal and in the mummy bandage Los Angeles 83. AI. 47. 1.4 dated to the Ptolemaic Period, it stands over a small socle. Socles, podia and pedestals usually served as base for cult images and boats of the gods during trips and séjours out of their temples. They therefore emphasize the divine status that the feathered eye enjoys in our image. Following the same idea, some manuscripts show a selection of yellow or golden tones, linked with the sun and the light, to depict some of the elements of the figure: in pLeiden T2 the eye is yellow-greenish, in KV 10 (right wall), pLondon BM 10470, pColonia 10207 and pCairo S.R. IV 692 the background of the oval is yellow, as the solar disc itself.

e| Glosses to spell 335 of the CT and chapter 17 of the BD related to the purification in the Heracleopolitan lakes as well as other passages in the same spell can shed some light on the identification of the logogram with Re. We may recall that one of them records: "as for that god who is therein (=the city), for whom the offerings are made by the rekhyt, he is Re himself'. The presence of the solar eye in our vignette can be a graphic way of reproducing this statement, by means of metonymy, where a fragment -the feathered eye of Horusrepresents the whole -the sun god-. The combination of sign and image (of solar eye inside a circle or oval) could be used to convey the idea that the god is present at (i.e, inside) the city ${ }^{125}$.

A second gloss of the same spell offers an explanation of another image of solar rebirth, featuring in this case the disc $(\mathrm{Re})$ emerging from a cow goddess:

$$
\begin{aligned}
& i w m 3 \sim n=i r^{c} p w \text { msy } m \text { sf hpdw } \\
& m h t-w r t, w \underline{d} 3=f, w \underline{d} 3=i, \underline{t} s \cdot \underline{p t r} r=f s w ? \\
& n w p w n n w t n(y) t p t \text {. kydd: twtpwn }
\end{aligned}
$$

121. Wb. III, 366, 7. We find an wedjat enclosed inside an oval-like hill among other representations of the sun god, which illustrate the Litany of Re depicted in a pillar of the funerary chamber in the tomb of Thutmose III (Wiese; Brodbeck, 2004: 62, fig. 9).

122. It has been argued that the logogram N5 ( $\odot$, usually used in connection with the sun) does not represent the sun as a phisical body but the iris and pupil of the divine solar eye instead (Ogdon, 1985: 37-38; Walle, 1985: 366, n. 13).

123. In the third division of the Book of the Caverns we find a snake coiled in a rectangular shape. Inside it have been depicted three ovals bearing two images of the sun (a simple[single?] eye and a ram's head) and one of Osiris (a human corpse). The scene expresses the amalgamation of Re and Osiris and decorated the tombs of Rameses VI (Piankoff; Rambova, 1954: pl. 20) and Rameses IX (Guilmant, 1907: pl. LII). In the fifth division of this same book (fig. 21), Nut is shown at the same time lifting Re in the forms of a ram-headed god and the sun disk and surrounded by images of this god representing the course of the luminary: beetle, ram, ram-headed god, human child, ram's head, disc and wedjat-eye (Hawass, 2006: 174-175, 185). Chapter 16 of the BD consists of a complex vignette related to the solar hymn in chapter 15 , in which the sun is also frequently depicted as an wedjat-eye inside a solar disc.

124. Coffin Cairo No Inv. 29660 (CGC 6213-6214-6182-6183-6184), Niwinski, 1988: pl. XXI, A.

125. This graphic pun is not far from the cryptographic spelling of Amun's name (Imn in Egyptian), as the bilateral sign $m n$ placed inside -imy in Egyptian- an oval ( $i m y+n=$ 'Imn), remarked by Egberts, 1995: 65, n. 111. 
$\underline{i r t} r^{\ulcorner} d w 3 r m s t=f r^{\complement} n b$. ir grt mhtwrt, wd3tpwn(y) $r^{c} n b^{126}$.

I have seen this Re who was born yesterday from the buttocks of Mehetueret and if he stays sound, I stay sound, and vice versa. What is that? It means these waters of the sky. Otherwise said: It means the image of the eye of Re in the morning for (=of) his birth every day. And as for Mehetueret, it is the wedjat every day.

The passage has a vignette of its own, whose main character is a cow lying next to an wedjat. We would like to highlight that the way of describing the daily emergence of the luminary in the horizon (=its rebirth) is under the form of Re's eye, a metaphor which suits the arguments brought forward in section $\mathrm{c} \mid$ regarding the condensation of the solar divine image in this motif.

We conclude that if the solar deity (either Re or Atum) is indeed represented in our vignette to emphasize his presence in the city and its lakes, then, the role of the pools as places for creation (and resurrection) would be strengthened by their relationship with a primeval and creator god. It is highly remarkable that Heryshef, the local deity of Heracleopolis Magna, developed in the course of time an aspect as creator god. This aspect links him with the process of genesis from the Nun, or to put it in other words, from the local pools that are fed by the Nun ${ }^{127}$.

We can go one step further by suggesting that both aspects, the solar (eye $=$ Atum $/ \mathrm{Re}$ ) and the funerary (eye $=$ praiseworthy deceased / $i m 3 h w$ ), of the sign are complementary. In fact, the ambiguity may have been intended in order to convey both meanings. In this sense, the logogram would symbolize the deceased who is raised again to life after cleansing in the lakes of the city, and afterwards proceeds to the horizon, identifying himself with the sun god.

As a concluding remark we will return to the reference at the beginning of this section regarding the paucity of contexts in which this motif is used. A brief review of funerary formulae outside where it appears in chapter 17 of the BD will serve to reinforce the solar hypothesis brought forward ${ }^{128}$.

In the lower register of a papyrus from Havana $^{129}$ we find a feathered eye, inserted in the image of cultivation of the Fields of Rushes. Since none of the manuscripts bearing this scene include a comparable element, it could be considered a unique case. In the light of our proposal equating the eye with a solar deity, the former could have been used here in substitution for one of the solar symbols recurrent in the vignette of chapter 110 of the BD as the Benu bird.

126. Urk. V, 37, 5- 38, 10, for the NK and later versions of the text; Lepsius, Tb., 1. 29-31; Naville, Tb., 1. 34-36. Translations in Allen, 1974: 29 (17 a § S 11) and Barguet, 2000: 60.

127. In the LP Heryshef receives a suggestive epithet: $m s w=f m \check{s} m m^{3} t$, "the one who is born in the Lake of Maat" (E. II, 81, 6 = Goebs, 1995: 173), which reminds us of the waking up of the creador-god amid the primeval waters.

128. Other instances depicting two feathered eyes arranged symmetrically and facing each other will not be analyzed here, because we consider them as unique variants inside their own (more usual) composition schemes and are far from our mythological context. We are referring to: 1: images of chapter 145 of the BD in the tomb of Djehutymes TT 31: two eyes are depicted crowning the chapels of two guardians -Kákosy et al., 2004: 74-75 (unit 2: BD 145 II), pl. XXXIV (BD $145 \mathrm{X}$ )-. The motif is exceptional in these friezes, where usually snakes, hekheru and feathers are depicted; 2: funerary scene in one short end of the sarcophagus of queen mntw-htp, dated to the end of the 17th Dynasty, found in Thebes, but actual place of location unknown. They are inscribed inside ovals and placed over two figures of Isis -PM I2: 605; texts and images are known by a facsimile copy by Wilkinson and recently published by Geisen, 2004 (see. ms Wilkinson dep a. 17, Fol. 22 r.)-. The usual motif to be represented on this spot are wedjat-eyes; 3: scene in the inner side of a coffin from the 21st Dynasty -Cairo 29660, Niwinski, 1988: pl. XXI, A-. It appears together with other symbols of solar and osirian resurrection, greatly widespread in this period of rich funerary imagery, that ensure the rebirth of the deceased.

129. pHavana Nacional Museum (Gumá Herrera Conde de Lagunillas Collection), $b 3 k-n-w r i, 19$ th/20th Dynasty, Thebes, Bellion, 1987: 160; Niwinski, 1989: 309 (Havana). 
In a mythological papyrus from the TIP we find a curious mixture of images (fig. 22): two enclosures called Abydos ( $3 b \underline{d} w)$ and northern Heliopolis (iwnw mhyt), guardians of lakes brandishing torches, the deceased positioned over a boat and offering tables ${ }^{130}$. Here an intermingling of funerary scenes has taken place that serves to symbolize the pilgrimage of the dead to these sacred centres and a ritual either for extinguishing torches (known by chapter $137 \mathrm{~A}$ of the $\mathrm{BD}$ ) or for protecting the access to certain areas of the Beyond (chapter $145 \mathrm{~V}$ of the BD). The latter chapter usually has a vignette composed of four deities similar to the figures of the mythological papyrus, standing beside lakes and bearing torches. The difference lies in that in chapter $145 \mathrm{~V}$ of the BD they are depicted next to gatekeepers protecting several doors of the Underworld ${ }^{131}$. Two elements render the document in Cairo unique. First, the guardian linked with the Heliopolitan enclosure performs with one hand a gesture of protection over a lake as do the characters in chapter 17 of the BD. Second, over the pool has been depicted the same feathered eye as in our chapter. If this type of eye were a solar symbol as we suggest, it can be related to the Heliopolitan and solar context of this part of the scene, which is indicated by the name of the guardian ( $n b \underline{h} r-\lceil h)$ and of the walled area (iwnw-mhyt).

In this first of three articles on the Heracleopolitan lakes we have stressed the key role of this landmark, focussing on the fol[64] lowing issues: its dominant position in the site (perhaps as a result of the natural flour-

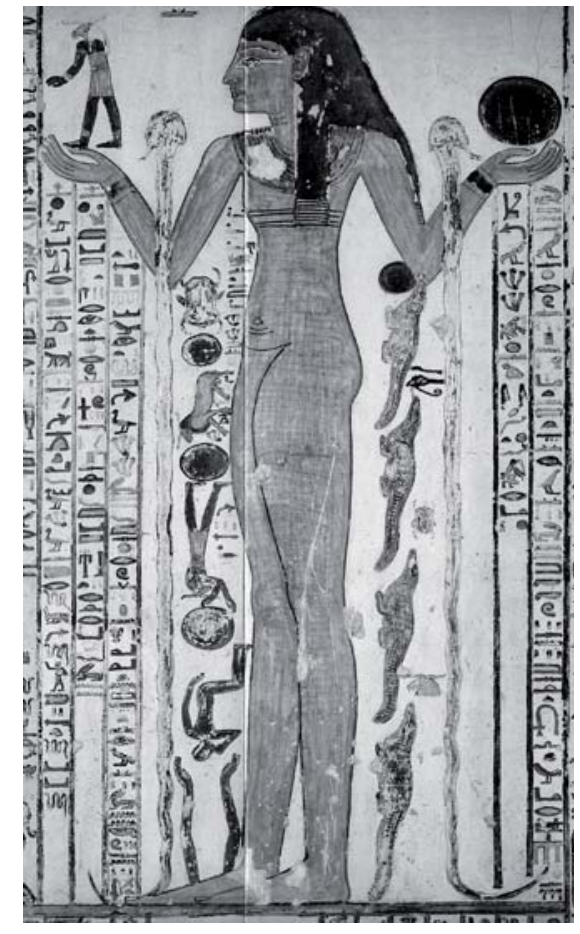

Figure 21. The goddess Nut surrounded by different forms of the sun god, fifth division of The Book of

Caverns depicted in KV 9 (Rameses V/VI); from Hawass 2006: 174-175

ishing of the water table), its relationship with the god Heryshef, its cultual use at the level of the local temple, its possible ideological or religious function in the royal sphere, and above all, its funerary projection to the landscape of the other world. As the main axis of the local theological speculation over the mythological role of the city, it is included in the popular spell 335 of the CT. The reproduction of the passage in chapter 17 of the $\mathrm{BD}$ proves the consolidation of the belief that the city is a signifi-

130. pCairo CG 40017, nsti-t3-nbt-t3wy, unknown provenance, Piankoff; Rambova, 1957: 93-103, Nr. 8 (specially 97-98).

131. The scene appears in the following papyri: 1: pParis BN 62-88, ‘ $n h-s-n-3 s t$, late 21 st Dynasty, unknown provenance; Bellion, 1987: 75; Niwinski, 1989: 351 (Paris 5); 2: pGatsesehn, Lucarelli, 2006: 218-219, pl. 45; 3: pLondon BM 10064, p(3)-n-nsty-t3wy, late 21st Dynasty, [Thebes]; Bellion, 1987: 59; Niwinski, 1989: 334 (London 49); Munro, 2001 a: 123. These three manuscripts, as well as pCairo CG 40017 (fig. 22) derive from a master copy preserved in pCairo JE $95879=$ S.R. IV 981, $p$ 3-di-imn, mid 21 st Dynasty, Thebes, Royal Cachette of Deir el-Bahari; Niwinski, 1989: 131, 268 (Cairo 44), pl. 11-16. 4: The four torch carriers are depicted once more in another manuscript, but they are set apart from the rest of gate keepers, as if they were an independent vignette -pCairo S.R. VII 11494, sd-sw-hrr, late 21st Dynasty, Thebes, Royal Cachette of Deir el-Bahari; Niwinski, 1989: 294 (Cairo 116). 


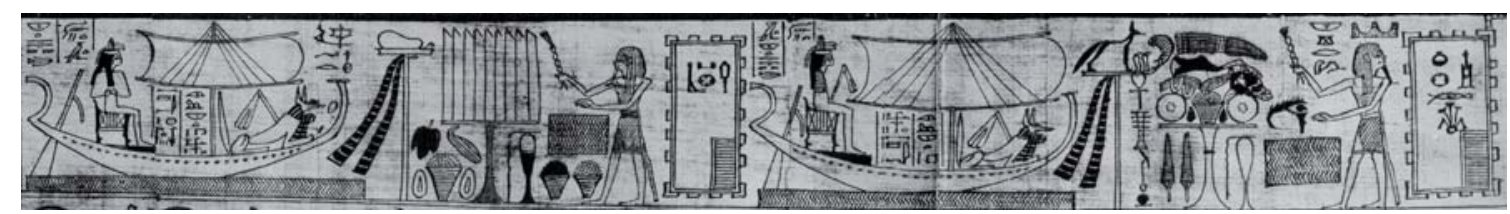

Figure 22. Mythological papyrus pCairo CG 40017,

TIP; from Piankoff; Rambova 1957: 93-103, Nr. 8.

cant place for the purification and rebirth of the deceased.

The analysis of the scene that is handed down to posterity together with or in place of the passage we have translated above, demonstrates that the pools of Heracleopolis Magna were regarded both as manifestations (and embodiments) of the primeval waters, from which the sun had emerged the first time, and as places for ritual cleansing suitable for a deceased person longing for rebirth. The idea that the lakes represent the primordial liquid is strengthened by their relation to the Nun, the names they received and their depiction as fecundity figures. It can also be linked with one of the aspects of the local god Heryshef as creator and primordial deity. 


\section{APPENDIX I: VignetTes IN Chapter 17 OF THE BD}

Where no bibliographical references are supplied under each entry of a manuscript, the document is yet unpublished, but its images were personally checked at the Papyrological Archive, in the Egyptological Seminar of the University of Bonn, with the kind support of Dr. Munro and the Totenbuch-Projekt team.

In order to evaluate the state of preservation of the scene of the Heracleopolitan lakes in the sources three categories have been devised. In diminishing order these are the following:

Good state of preservation -if the vignette is wholly preserved;

Damaged image -if the image is partially damaged, but all its elements are recognizable;

Fragmentary state -if owing to the presence of lacunae some of the elements are blurred or have disappeared.

Under the heading "extra sources" are quoted other documents that belong to the same manuscript. "p" stands for papyrus; "M" for mummy bandage; "TT" for Theban Tomb; "KV" for Valley of the Kings; "QV" for Valley of the Queen; "Kat" for catalogue.

\section{Th- 20Th Dynasties}

\section{[66 ] Papyri}

pLondon BM 10471 + pLondon BM 10473, nht , dated between the end of the 18th Dynasty and 19h Dynasty, Thebes. Good state of preservation.

Seeber, 1976: 202 (13), places it in the group of papyri belonging to the 18th Dynasty; Baines, 1985: 380, z) document 5; Bellion, 1987: 69-70, dates it to the time of Sety I; Munro, 1988: 300
(Kat. b. $20^{1}$ ), situates it in the 19th-20th Dynasties; Quirke, 1993: 47 (119), 77, n. 121, dates pLondon BM 10471 to the 18th Dynasty.

pLondon BM 9901, $h w-n f r$, Thebes. Good state of preservation.

Naville, Tb, A.g., Taf. XXVIII; Seeber, 1976: 203 (1) and Bellion, 1987: 49 places it in the time of Sety I; Baines, 1985: 380, z) document 2; Munro, 1988: 302 (Kat. b. 28); Quirke, 1993: 41 (89), 75, n. 89; Faulkner, 1994: 46, below.

pLondon BM 10470, 3ni, Thebes. Good state of preservation.

Seeber, 1976: 203 (4), 66, fig. 14; Geßler-Löhr, 1983: 221, Abb. 46; Baines, 1985: 380, z) document 4; Bellion, 1987: 69; Munro, 1988: 296 (Kat b. 1); Quirke, 1993: 32 (24), 71, n. 24; Faulkner, 1994: pl. 8.

pLeiden T 2, knn3, beginning of the 19th Dynasty, Thebes. Good state of preservation.

Naville, Tb, L.a., Taf. XXVIII; Leemans, 1882: pl. IX; Seeber, 1976: 204 (6); Bellion, 1987: 175-176; Munro, 1988: 303 (Kat. b. 33); Baines, 1985: 380, z) document 1.

pMoscow I, 1b, 133 (Pushkin Museum), [wsr-] h3t (name reconstructed from pMoscow I, 1b, 160), unknown provenance. Extra sources: pMoscow I, 1b, 13; I, 1b, 14; I, 1b, 15; I, 1b, 160. Fragmentary state; the scene appears in fragments 11 and 12.

pBerlin 3002 a-z, $n$ htt-imn, time of Rameses II, unknown provenance (Thebes?). Fragmentary state.

Naville, Tb, B. a., Taf. XXVIII; Seeber, 1976: 203 (2); Bellion, 1987: 23-24; Munro, 1988: 300-301 (Kat. b. 22); Munro, 1997: Taf. 4; RößlerLöhr, 1999: 19-20.

1. Papyri classified under letter "b" belong to the 19th/20th Dynasties according to Munro, 1988: 333, n. 754 . 
pDublin Inv. 1661 (Trinity Collage Library), middle years of Rameses II's reign, unknown provenance. Good state of preservation.

Naville, Tb, D.a., Taf. XXVIII; Bellion, 1987: 141 (=pDublin 4); Munro, 1988: 307 (Kat. b. 60); Rößler-Köhler, 1999: 21.

pLondon BM 9949, ḩ3rwi, 19th-20th Dynasty, [Memphis]. Damaged image.

Naville, Tb, A.p., Taf. XXVIII; Seeber, 1976: 203 (3); Baines, 1985: 380, z) document 3; Bellion, 1987: 52; Munro, 1988: 307 (Kat. b. 58); Quirke, 1993: 44 (105), 76, n. 105; Rößler-Köhler, 1999: 24-25.

pLeiden T4, $p 3-k r r$, 19th Dynasty, Memphis. Fragmentary state.

Naville, Tb, L.e.; Bellion, 1987: 176-177; Munro, 1988: 298 (Kat. b. 11); Rößler-Köhler, 1999: 25-27.

\section{Other media}

Osireion or cenotaph of Sety I, Abydos. Damaged image.

Frankfort, 1933: I, 66 and vol II, pl. 68-69.

KV 10, tomb of imn-ms, Thebes. The vignette was represented twice in the right and left walls of the second chamber. Good state of preservation.

PM I²: 2, 518 (6), (7); Baines, 1985: 381, z); Lefébure, 1889: pl. 56 (upper and central images).

QV 66, tomb of Nefertari, Thebes. First chamber. Fragmentary state.

PM I²: 2, 762 (2)-(4) I; Thausing; Goedicke, 1971: pl. 22; Baines, 1985: 380, z) document 6.
TT 32, tomb of $\underline{d} h w t y-m s w$, time of Rameses II, Khokha. Fragmentary state.

PM I²: 1, 50 (9); Kákosy et al., 2004: 197, 17/6, 347.

TT 135, tomb of $b k$-imn, Gurna. Damaged image.

$\mathrm{PM} \mathrm{I}^{2}$ : 1, 251; Baines, 1985: 326 and fig. 185.

TT 265, tomb of imn-m-ipt, Deir el-Medina. Damaged image.

PM I$^{2}$ : I, 346 (4) I (partial description); Saleh, 1984: 99 (dates it to the time of Sety I) Abb. 12; Baines, 1985: 381, z) document 8; Rößler-Köhler, 1999: 12-13, dates it to the first half of Rameses II's reign.

JE 27302, funerary chapel over sledge of hnsw, time of Rameses II, found in his father's tomb, Sennedjem, at Deir el-Medina. Good state of preservation.

PM I' ${ }^{2}$ 1, 5; Desroches-Noblecourt, 1976: 194-205; Baines, 1985: 381, z) document 7.

Tomb of ini-hr(t)-ms, time of Merneptah, El-Mashayikh (Bhdt-i`btt, Lepidotonpolis, Thinite nome). Damaged image.

PM V: 28-29 (omits reference to vignette); Ockinga; Al-Masri, 1990: 5-6, pls. 2 and 9.

Papyri in which only a part of the vignette of chapter 17 of the BD is preserved but might have included the scene of the Heracleopolitan lakes:

pNew York, Amherset 33, sh. 1+2+3 (Pierpont Morgan Library), si, 18th-19th Dynasties.

Newberry, 1899: 52.

pBrussels E. 5043, nfr-rnpt, time of Rameses II, 
found in TT 336, Thebes.

Bellion, 1987: 96-97; Munro, 1988: 299-300 (Kat. b. 18); Rößler-Köhler, 1999: 14-15.

pCairo JE 95720 (*16), $t 3 i$, 19th- 20th Dynasties, Saqqara.

Munro, 1988: 301 (Kat. b. 26).

pLondon UC 71002 B, unknown provenance.

pLondon BM 9940, krtn/nfr-rnpt, [Thebes]. Only text preserved of chapter 17 of the BD, but there was probably a vignette in the upper missing part.

Bellion, 1987: 51; Munro, 1988: 304 (Kat, b. 42); Quirke, 1993: 48 (129), 78, n. 129; RößlerKöhler, 1999: 16-17.

pCracow MNK IX-752/1, 2, 3, 4, (Narodowe Museum), pth-ms, [Thebes]. Extra source: pLouvre SN2 (preserves the image).

Van es, 1982; Bellion, 1987: 132, 224; Munro, 1988: 298-299 (Kat. b. 13); Rößler-Köhler, 1999: 18-19.

\section{1st DyNasty}

\section{Papyri}

pBerlin 3157, $m w t-m$-wi3, mid-late 21st Dynasty, [Thebes]. Good state of preservation.

Naville, Tb, B.b., Taf. XXVIII; Bellion, 1987: 33, dates it to the 19th Dynasty as well as Munro, 1988: 299 (Kat. b. 14); Niwinski, 1989: 251 (Berlin 27), suggests it belongs to the same workshop or stems from the same mastercopy as Cairo 19, Cairo 59, Cairo 90 and Geneva; RößlerKöhler, 1999: 100-101.

pCologny C (Bodmeriana Library, Martin Bodmer Fondation, also called pBodmer C), ini-ph-f-nht, mid 21st Dynasty, [Thebes]. Good state of preservation.

Bellion, 1987: 361; Niwinski, 1989: 308 (Geneva); Munro, 2001: 114 (47); Rößler-Köhler, 1999: 131; Valloglia, 2001: 135-145, figs. 32, 39.

pLondon BM 10554 (pGreenfield), nsi-t3-nbt-3šr w, late 21st Dynasty - early 22nd Dynasty, Thebes, Royal Cachette of Deir el-Bahari. The vignette is repeated twice, illustrating chapter 17 of the BD and a solar hymn. Good state of preservation.

Budge, 1912: pl. X, LXXXIV; Bellion, 1987: 157; Niwinski, 1989: 155-157, 338 (London 61); Quirke, 1993: 50 (145), 79, n. 145; Rößler-Köhler, 1999: 95-98; Munro, 2001: 124 (199).

Papyri in which only a part of the vignette of chapter 17 of the BD is preserved but might have included the scene of the Heracleopolitan lakes:

pLondon BM 10541 (pndimt A, 2 fragments), earlymid 21st Dynasty, Thebes, Royal Cachette of Deir el-Bahari. Extra sources: pParis Louvre E. 6258 (pndint A), pMunich ÄS 825 lost during 2nd World War, probably included image of lakes.

Seeber, 1976: 210 (1); Bellion, 1987: 239-240; Munro, 1988: 301 (Kat. b. 24); ead., 2001: 124 (198); Niwinski, 1989: 337-338 (London 60), 362 (Paris 47), type BD.II.1.; Quirke, 1993: 47 (126), 78, n. 126; Rößler-Köhler, 1999: 79-80.

\section{Late Period}

pCairo S.R. IV 692, $t 3-\check{s} r t-(n)-3 s t$, 26th Dynasty (ca. $530 \mathrm{BC}$ ), Thebes. Extra sources: pHeidelberg Universität 566 -Burkard; Fischer-Elfert, 189-191 (Kat. Nr. 284), pCairo S.R. IV 938, pCairo S.R. IV 939, pCairo S.R. IV 964, pHeidelberg Portheim Stiftung, pNew York IFA, pAssisi 351 (alt: 20 a), pJerusalem Bible Lands Museum H 376, pCairo S.R. IV 615. Fragmentary state. 
Vignette split between pHeidelberg 566, pCairo S.R. IV 692 and pCairo S.R. IV 939.

Publication in preparation by Dr. I. Munro.

pTheben / Ramesseum (1), nhm-sw-mwt, 26th Dynasty, Ramesseum (Thebes). Good state of preservation.

Leblanc; Nelson, 1997: 74 and 77, pl. XXIA.

pColonia Aeg. 10207 (Seminar für Ägyptologie), i`h-t3i-s-nht, mid 26th Dynasty (600 BC), Abusir el-Meleq (Heracleopolis Magna). Fragmentary state.

Seeber, 1976: 223 (28); Burkard ; FischerElfert: 178-179 (Kat. Nr. 268); Verhoeven, 1993: I, 48-50, III, beilage 3 .

pLondon BM 10558, `nh-w3h-ib-r`', 26th Dynasty, [Memphis]. Good state of preservation.

Seeber, 1976: 223 (18); Bellion, 1987: 72, dates it to the Roman Period; Quirke, 1993: 32 (23), 71 , n. 23.

pParis Louvre N. 3091, late 26th Dynasty (time of Amasis), 1) 'r-pth-hpw 2) mn-n-w3h-ib-r', Memphis. Fragmentary state.

Déveria, 1881: 62-64 (III. 14); Bellion, 1987: 197.

\section{Last Dynasties}

\section{Papyri}

pParis Louvre N 3094, $t 3$ i- $h p$-im- $w$, between the Late and Ptolemaic Period, [Thebes]. Good state of preservation.

Déveria, 1881: 121 (III. 121); Seeber, 1976: 224 (45); Bellion, 1987: 199; Charron, 2002: Nr. 73, 152-171, pls. 152-153.
pLondon BM 10539 + 10700 + 10733, $p$ 3-di-imn- $n b-$ $n s t-t 3 w y, 30$ th Dynasty - early Ptolemaic Period, Thebes. Fragmentary state.

Quirke, 1993: 52 (156), 80, n. 156; Bietak; Hauslauer, 1982: 274 (G 65 + 66).

pParis BN 94-95 y 112-117, $w 3$ h-i $i b-r^{c}, 30$ th Dynasty - early Ptolemaic Period, Thebes. Extra sources: pUnknown location (Christies' Sales catalogue, South Kensington Antiquities, Wednesday 12th April 2000, 51, Lot 99). Fragmentary state.

Bellion, 1987: 76; Néret, 1995: Taf. 246-247 (=A. Vol. II, pl. 70).

pVatican $\mathbf{N}^{\circ}$ Inv. 38.571 = Vatican 48, $n s-p 3 w t y-t 3 w y$, 30th Dynasty - early Ptolemaic Period, Thebes. Extra sources: pAmsterdam UB 26 (A), pDallas Public Library, pLecce PUL inv. I4, pLondon BM 10289. Good state of preservation.

Bellion, 1987: 319; Gasse, 1993: 38-39 (n² 25), pl. XXXI.

pVatican $\mathbf{N}^{\mathbf{0}}$ Inv. 48.832 = Vatican 1 (N. 16), p3-šr $n$ - $t 3$-iht $\underline{d} d$ psmtk, Saite- Persian Period (according to Yoyotte, 1971: 18-20 and Bellion); PersianPtolemaic Period (Allen, 1960: 40-41); last native Dynasties according to Gasse, Memphis. Good state of preservation.

Seeber, 1976: 227 (106); Bellion, 1987: 315; Gasse, 1993: 35-36 (n $\left.{ }^{\circ} 23\right)$; ead., 2001: 13-14.

pNew York MMA 35.9.20, $i l-m-h t p, 30$ th Dynasty - early Ptolemaic Period, Meir. The row of vignettes does not follow the order of the text. Damaged image.

Bellion, 1987: 229; Clère, J.J., in preparation (according to Logan, 1978: "Varia Metropolitana II", GM27: 33-34, n. 2).

Papyri and mummy bandages (Late Period and last native Dynasties) in which only a part 
of the vignette of chapter 17 of the BD is preserved but might have included the scene of the Heracleopolitan lakes:

pChicago OIM 5739, `nh-pf-hri, 26th-30th Dynasties, Abydos.

Allen, 1960: 14-15, pl. 10; Bellion, 1987: 128; Mosher, 1990: 650.

pFlorence 11912 a-b (Museo Egizio), $h 3 m-h r$, 26th Dynasty, [Thebes]. Extra sources: pAnn Arbor KM 81.4.25, pNew York MMA 25.3.212 A-G, pProvidence A18077.

Bosticco, 1957: 71-76, figs. 1-2.

M. London UC 32405, $h p w-[m n(?)], h p w-[m n h$ (?)] Late Period, unknown provenance.

M. London UC 32377, $t 3-s 3 w(n-) ` n h$, Late Period, unknown provenance.

pLondon UC 71075, ns-hnnsw, 26th Dynasty, unknown provenance. Extra source: pFlorence 3668 .

pNeuchâtel 242 (Musée d'Ethnographie, Rue Saint Nicolas 4, Guillaume de Perregaux Collection), [p]smtk, 26th Dynasty, Thebes.

M. Berlin 411, 1-14 (Staatsbibliothek Ms. or. Quart.), hr-ḩbi, Late - Ptolemaic Period, Saqqara.

[ 70 ] pTomb of Ankh-Hor Reg. Nr. 873, 30th Dynasty - early Ptolemaic Period, $p 3-h b$, Thebes, Assassif.

Bietak; Hausler, 1982: II, 254, 272 (G53, 873).

\section{Ptolemaic Period ${ }^{2}$}

\section{Papyri}

Thebes $^{3}$

pAberdeen ABDUA 84023, 1-7, $p 3$ - $d i-h r w-p 3-\underline{h} r d$, 4th century BC, [Thebes]. Good state of preservation.

Curtis; Kockelmann; Munro, 2005: 52-53, 69, fig. 2 .

pBerlin P. 3158 A-G, rrtt, 4th century BC, [Thebes] Fragmentary state.

Kaplony-Heckel, 44 (Kat. Nr. 83); Seeber, 1976: 222 (13); Bellion, 1987: 33.

pSt Petersburg 3531 (Hermitage), $n s-m n w / p 3$ ( $m n w)$, 4th century BC, [Thebes]. Damaged image.

Piotrovsky, 1974: Nr. 135; Seeber, 1976: 224 (35); Bellion, 1987: 146, dates it to the PersianPtolemaic Period.

pDetroit 1988.10, $n s-m n w$, early Ptolemaic Period, [Thebes]. Good state of preservation.

Bulletin of the Detroit Institute of Arts 74, $\mathrm{n}^{\circ} 1 /$ 2, 2000: 20-31 (Totenbuch-Projekt reference ${ }^{4}$ ).

pParis BN 1/19 (pCadet), p3-di-imn-nb-nst-t3wy, early Ptolemaic Period. Good state of preservation.

Seeber, 1976: 228 (116); Bellion, 1987: 99-100; Néret, 1995: 250-251, Taf. 75 (A. Vol. II, pl. 75).

pParis BN 24-32, $p 3-d i-h r-p 3-r^{r}$, early Ptolemaic Period, [Thebes]. Good state of preservation.

Seeber, 1976: 226 (71); Bellion, 1987: 74.

2. Exception made of more accurately dated documents, the rest of sources belong to the Ptolemaic Period widely understood.

3. In documents of Ptolemaic date, if provenance is placed between square brackets, the location has been assigned by such criteria as the owner's titulature or prosoprographic analysis, not for having been found in situ.

4. "Totenbuch-Projekt reference" means that even though the document was analyzed at the Papyri Archive in Bonn, the publication indicated in the record card of the Archive could not be personally checked. 
pParis Louvre N. 3129 + E. 4890 B, p3-šrí- (n) $m n w \underline{d} d-t w n=f w s i r-w r$, early Ptolemaic Period, [Thebes]. Extra sources: pCracow XI 1503-06, 1508-11, pAmherst 30, pBrussels E. 4976. Damaged image.

Déveria, 1881: 93 (III. 55); Bellion, 1987: 202-203; Mosher, 1990: 93-95 (style 1, group B), 507 (suggests dating it between $250-200 \mathrm{BC}$ ), 647, pl. 35; Verhoeven, 1998: 225-227.

pLondon BM 10097, p3-di- $\boldsymbol{s} s t, 330-320 \mathrm{BC}$, [Thebes]. Damaged image.

Bellion, 1987: 61; Quirke, 1993: 52 (158), 80, n. 158.

pParis Louvre N. 3152, ššnk, late 4th century early 3 rd century BC, [Thebes]. Good state of preservation.

Déveria, 1874: 105-106(III. 75); Seeber, 1976: 225 (55); Bellion, 1987: 205, dates it to the Third Intermediate Period; Mosher, 1990: 101-104, 507 (suggests dating it between the Saite Period and early Ptolemaic Period), 647, pl. 33 (style 1, group A).

pFrankfurt SUB 1 (Stadt und Universität Bibliothek), hr-m-3h-bit, 4th -3rd century BC, tomb of Ankh-Hor, follows memphite style. Extra sources: pBologna KS 3170 a-e, pBristol H 3687, pLondon BM 10272, 10734, 74329. Fragmentary state.

Burkard; Fischer-Elfert: 303 (Kat. Nr. 303); Bietak; Haslauer, 1982: 280 (G 125).

pCopenhagen AAe 1 (National Museum), $t 3-k r-h b$, 300 BC. Good state of preservation.

Buhl, 1974: 24-25, ${ }^{\circ}$ 9; Seeber, 1976: 223 (29); Bellion, 1987: 130.

pLondon BM 10037, $h r-n \underline{d}-h r$-it-f, time of Ptolemy III (246-221 BC) or later, tomb in Assassif. Good state of preservation.
PM I: II, 623-624; Bellion, 1987: 57, dates it to the 26th Dynasty; Quirke, 1993: 40 (80), 74, n. 80.

pParis Louvre N. 3079, $\underline{d} d-\underline{h} r$, late 3rd century - early 2 nd century BC, Armant. Fragmentary state.

Devéria, 1874: 123-124 (III, 99); De Rougé, 1861-1876: pl. XIV; Seeber, 1976: 224 (38); Bellion, 1987: 194-195; Mosher, 1990: 61-65, 507 (suggests dating it between $280-250$ BC), 645, pl. 32 (style 1, group A).

pCologny CIV, wsir-wr, 200 BC, [Thebes]. Good state of preservation.

Valloglia, 2000: 139-140, 142, pictures 121, 123,130 .

pBerlin P. 3039 A-E, F-Q, šm-in-n-i. Fragmentary state.

Seeber, 1976: 222 (5); Bellion, 1987: 28.

pLeiden T16, 3st-wrt. Good state of preservation.

Leemans, 1867-1876: pl. VIII; Seeber, 1976: 224 (32); Bellion, 1987: 178.

pLondon BM $10082 \mathrm{~A}+\mathbf{1 0 3 1 6}$ (images of lakes in 10316 / 5), hr-s3-3st. Extra source: pTurin 1836. Good state of preservation.

Quirke, 1993: 41 (86), 75, n. 85-86; Verhoeven, 1998: 211-232, pl. XXVIII.

pMailand E. 1028 a-f (Civiche Raccolte Archeologiche e Numismatiche, E. 0.9.40146), 3st-wrt, Luxor. Fragmentary state.

Lise, 1979: Nr. 72, Taf. 94-100; Tiradritti, 1999: 147, 173, Cat. 163.

pTurin 1791, $i w-f-{ }^{-} n h$. Good state of preservation.

Lepsius, 1842: Taf. L; Seeber, 1976: 226 (74); Bellion, 1987: 275, dates it to the Saite 
Period; Limme, 1983: 94, assigns it a date between 200-100 BC; Mosher, 1990: 120 (in n. 137 and 507 points out probable date to the 2nd or 1 st century BC), 457, 651, pl. 38 (style 2 , group B).

pGeneva 23464 / 1-6 (Musée d'Art et d'Histoire), $t 3-w 3 t / 3 s t$ wrt, [Thebes]. Good state of preservation.

Exhibition catalogue Werke ägyptischer Kunst von der Frühzeit bis zur spätantike: 44, nº 117, Taf. 25-36 (Totenbuch-Projekt reference); Chappaz; Poggia, 1996: 32.

pLeiden T20, $\underline{d} d-h r$, [Thebes]. Extra source: pParis Louvre N. 3128. Good state of preservation.

Bellion, 1987: 179; Coenen, 1999: 71-73.

pLondon BM 10086, $t 3$-nt-imn-ii, [Thebes]. Good state of preservation.

Quirke, 1993: 65-66 (258); Mosher, 2001: pl. 20,2 .

pLondon BM 10257, $h r-m-h b$, [Thebes]. Extra source: pParis Louvre N 3255. Good state of preservation.

Bellion, 1987: 64, dates it to the 26th Dynasty, 214; Quirke, 1993: 40 (78), 74, n. 78.

pMunich Mon. Script. Hierogl. 1 (Staatliches Museum Ägyptischer Kunst, Leihgabe Bayr.

[72 ] Staatsbibliothek), previously called pMünchen Codex hierat. 1, p3-iw-hr, [Thebes]. Extra sources: pMunich Mon. Scripr. Hierogl. 4 a and 4 b. Good state of preservation, but scene divided between two pages.

Bellion, 1987: 236, dates it between the 6th-4th century BC; Schoske, S. (1995): "Staatliches Sammlung Ägyptischer Kunst München”. Zaberns Bildbande zur Archäologie 31, Maiz: 22-23, Abb. 19 (Totenbuch-Projekt reference).
pParis Louvre E. 7716, $t 3$-ḩi-bi3t, [Thebes]. Good state of preservation.

Mosher, 1990: 116, 468, 507 (suggests dating it between the Saite Period (?) and early Ptolemaic Period), 649, pl. 33 (style 1, group A) .

pParis Louvre N. 3087, $n h m-s-r^{\top} t-t 3 w y$, [Thebes]. Good state of preservation.

Dèveria, 1874: 83 (III. 39); Seeber, 1976: 224 (42); Bellion, 1987: 197, dates it between the 26th Dynasty and Ptolemaic Period; Mosher, 1990: 81.82, 507 (suggests dating it between the Saite Period (?) and early Ptolemaic Period), 646, pl. 32 (style 1, group A).

pParis Louvre N. 3089, ššnk, [Thebes]. Good state of preservation.

Dèveria, 1881: 104-105 (III. 74); Seeber, 1976: 224 (43); Bellion, 1987: 197, dates it to the Third Intermediate Period; Mosher, 1990: 85-86, 507 (suggests dating it between 250 - 240 BC), 646, pl. 34 (style 1, group B).

pParis Louvre N. $3090+$ N. $3206+$ N. 3198, $p 3-b r r$ $\underline{d} d=t w n=f p 3$-di-imn-m-ipt $/ p$ 3-di-imn-m-ipt $d d=t w$ $n=f p$ 3-brr, [Thebes]. Good state of preservation.

Déveria, 1874: 99-100 (III. 65); Bellion, 1987: 197; Mosher, 1990: 86-89, 454-455, 507 (suggests dating it between $250-200 \mathrm{BC}$ ), 646, pl. 34 (style 1, group B).

pParis Louvre N. 3149, 3204 B, 3123 bis + 3213, nḥm$s-r^{r} t-t 3 w y$, [Armant]. Good state of preservation.

Dèveria, 1874: 82-83 (III. 38); Bellion, 1987: 205.

pParis Louvre N. 3248, $t i-b \underline{h} / t i-b 3-3 h t$, [Thebes]. Fragmentary state.

Dèveria, 1881: 107-109 (III. 77); Seeber, 1976: 225 (58); Bellion, 1987: 213-214; Mosher, 1990: 
107-109, 507 (suggests dating it between 250 200 BC), 648, pl. 37 (style 1, group B).

pTurin 1831, $p$ 3-di-imn-nb-nst-t3wy, [Thebes]. Good state of preservation.

Seeber, 1976: 227 (99); Bellion, 1987: 279, dates it between the 26th Dynasty and Ptolemaic Period.

pTurin 1833, $t 3 i-s-n h t$, [Thebes]. Good state of preservation.

Seeber, 1976: 227 (101); Bellion, 1987: 279-280, dates it between the 26th Dynasty and Ptolemaic Period.

pUnknown provenance, $t 3-b r$, [Thebes]. Extra source: pDublin 1669. Fragmentary state.

Writing \& Lettering in Antiquity, Charles Ede Ltd, $3^{\text {rd }}$ May 1978, Nr. 17 a, b.

\section{Memphis}

pCairo CG. 40029 (JE 95837, S.R. IV 934), $d s r$, 3rd century BC. Extra sources: pCairo S.R. IV 551 and 996. Fragmentary state.

pParis Louvre N. 5450, wnn-nfr, first half of the 3rd century BC, [Memphis]. Fragmentary state.

Dèveria, 1881: 95-96 (III. 58); Seeber, 1976: 225 (63); Bellion, 1987: 220, dates it between the 26th Dynasty and Ptolemaic Period; Mosher, 1990: 114-115, 459, 507 (suggests dating between 280 250 BC), 649, pl. 39 (style 3, subgroup A).

pVienna Vindob. Aeg. 65, $t t-r w-m w / t 3-i r w, 3$ rd- 2nd century BC, [Memphis]. Good state of preservation.

Loebenstein, 1972³: 32, Nr. 70; Seeber, 1976: 228 (114); Bellion, 1987: 321.
pParis Louvre N 3081, 1) hr-nd-it-f2) ---- 3) p3-di$h k 3,3$ rd- 2nd century BC, [Memphis]. Good state of preservation.

Dèveria, 1881: 65-66 (III. 16); Seeber, 1976: 224 (39); Bellion, 1987: 195-196; Mosher, 1990: 65-68, 459-460, 507 (suggests dating between 250 - 200 BC), 645, pl. 38 (style 3); Barguet, 2000: strip of vignettes over pages 57-60.

pLeiden T17, psmtk , time of Ptolemy VIII (mid 2nd century BC), Memphis. Good state of preservation.

Seeber, 1976: 224 (33); Bellion, 1987: 178; Quirke, 1999 b: 40-42, pls. 12-23.

pBerlin P. 3149, $h^{\complement}-h p$, [Memphis]. Extra source: pBerlin P 14376. Fragmentary state.

Kaplony-Heckel: 41 (Kat. Nr. 74) and 98 (Kat. Nr. 286).

pCairo JE 32887 (S.R. IV 930), hrw, [Memphis]. Fragmentary state.

pVienna ÄS 3862 (3856-58, 3862, 3864, 3866-69) + 10159 (Kunsthistorische Museum), hnsw-iw, 249 BC, [Memphis]. Extra sources: pLondon BM $10045+10322$, pManchester hieratic Nr 4, pOxford Ms Egypt a.1 (P) + b.2 (p), pZagreb 886. Good state of preservation.

Seeber, 1976: 228 (113); Quirke, 1993: 44 (76), 76, n. 108; Satzinger, 1994: 34-35, Abb. 20 c.

pVienna Vindob. Aeg. 10.110 (Österreichische Nationalbibliothek), $n f r-s b k$, [Memphis]. Fragmentary state.

\section{$\operatorname{Akhmin}^{5}$}

pBerlin P. 10477, $n f$ - ili-n- $i$ (Lüscher) $n f r t-i ̉$, second half of the 3rd century BC. Good state of preservation.

5. Mosher, 2001: chapters 2-3, includes six papyri in the tradition of Akhmin (so-called after himself) and dates them in the late Ptolemaic Period. Among these, pHildesheim 5248 is the only one that omits most of the scenes of chapter 17 of the BD. 
Seeber, 1976: 223 (15); Bellion, 1987: 42; Lüscher, 2000: 25-26, Taf. 6; Mosher, 2001: 6, n. 2, 9, 30, fig. 6 .

pLondon BM 10479, $h r$. Good state of preservation.

Bellion, 1987: 72, dates it to the Saite Period; Quirke, 1993: 39 (72), 74, n. 72; Mosher, 2001: $1-4,8,28$, fig. 1, pl. $3=$ pl. 21,1 .

pMacGregor, $t 3-r-p t / t 3-r p i t$, private collection (previous Tamworth, Mac Gregor Collection 525). Damaged image.

Bellion, 1987: 226, dates it to the 26th Dynasty; Mosher, 2001: 4-5, 6 n. 9, 9, 29, fig. 5, pl. 13, $2=$ pl. $21,2$.

pNew Brunswick (N.J. Theological Seminar), $n s$ mnw. Good state of preservation.

Clère, 1987: pl. IV; Mosher, 2001: 8-9, 29, fig. 3.

pParis Louvre E. 11078, $p 3-s n \underline{d}-i b-i b h \underline{h} t \underline{d} d=t w n=f$ twtw. Good state of preservation.

Bellion, 1987: 222; Mosher, 2001: 36, assigns it a Theban origin around the 1 st century BC.

\section{Middle Egypt}

pChicago OIM 10486 (pMilbank), irti-w-r-w, Ptolemaic-Roman Period, Middle Egypt (?). Good state of preservation.

Allen, 1960: 39-60, pl. 60; Seeber, 1976: 223 (21); Mosher, 1990: 116-117, 458, 460, 496, 507 (suggests date between $200 \mathrm{BC}$ and Roman Period), 650 (style 2); Allen, 1992-1993: 141 (publication soon to be announced).

\section{Unknown Provenance}

pChicago OIM 9787 (pRyerson), nsỉ-šw-tfnt,
400-300 BC (Allen y Seeber suggest Persian Ptolemaic date). Good state of preservation.

Allen, 1960: 16-39, pl. 13 (suggest it comes from Edfu, n. 12); Seeber 1976: 223 (20); Baines, 1985: 381, z) document 9; Bellion, 1987: 128; Mosher, 1990: 118-120, 455-456, 507 (points out date between 250 - 200 BC), 651, pl. 37 (style 1, group B).

pLondon BM 10844, mn, late Ptolemaic Period. Extra source: pLondon BM 10098. Good state of preservation.

Bellion, 1987: 61; Quirke, 1993: 44 (111); id., 1999: 91, dates it to the second half of the $1 \mathrm{st}$ century BC, Cleopatra's reign.

pAngers MTC 747 (Musée Pincé), [-] t3wy (?). Good state of preservation.

Affholder-Gérard; Cornic, 1990: 89-90, pl. 70.

pBerlin 3003 A-K, kki3. Good state of preservation.

Seeber, 1976: 222 (2); Bellion, 1987: 24, dates it to the 26th Dynasty; Von Falck, 2006: 52, Tf. 4.

pCairo JE 95859 (S.R. IV 958), ‘nhh-tkrt. Good state of preservation.

pCambridge (Ma) (Harvard University, Houghton Library). Fragmentary state.

pLondon BM 10465 + 10539 pt, `nh-wr-mr. Fragmentary state.

Quirke, 1993: 32 (21).

pMainz Gutenberg Museum Hs 22, $p 3$-diwsir $\underline{d} d=t w n=f$ irt- $h r w-r-w$. Extra sources: pManchester Hieratic 3, pToronto ROM 909.80.515.1-3, pToronto ROM 909.80.516, pVic without number. Damaged image. 
Burkard; Fischer-Elfert, 214-215 (Kat. Nr. 317); Halbey, H.A., et al. (1992³ [1985]): Buchkultur in Mainz, Schrift Druck Buch im Gutenburg Museum, Mainz, 15-16, Nr. 7, Abb. (TotenbuchProjekt reference).

pOslo "Lieblein Papyrus" (University Library), $h r w$-wn-nfr. Good state of preservation.

pParis BN 141-148, $p 3-d i-n f r-h t p$. Good state of preservation.

Bellion, 1987: 76, dates it to the Saite Dynasty.

pParis Louvre E. 3232, $i w-m-h t p$. Good state of preservation.

Déveria, 1881: 72 (III. 28); Bellion, 1987: 212; Mosher, 1990: 105-106, 507 (suggests dating it between the Saite Dynasty and early Ptolemaic Period), 648, pl. 32 (style 2, group A).

pParis Louvre E. 6130, 3st-rštti. Fragmentary state.

Déveria, 1881: 75 (III, 32); Seeber, 1976: 225 (64); Bellion, 1987: 220, dates it between the 26th Dynasty and Ptolemaic Period; Mosher, 1990: 115, 649, pl. 39 (style 1).

pParis Louvre N. 3100, ns-pth. Extra source: pLondon UC 32373. Good state of preservation.

Déveria, 1874: 85-86 (III. 43); Seeber, 1976: 225 (48); Bellion, 1987: 200; Mosher, 1990 92-93, 507 (suggests dating it between 200 BC and Roman Period), 647, pl. 35 (style 2).

pParis Louvre N. 3153, $n s-p 3-m d w$. Good state of preservation.

Déveria, 1874: 84-85, (III. 42); Seeber, 1976: 225 (56); Bellion, 1987: 205-206; Mosher, 1990: 104-105, 456-457, 507 (suggests date between 250-240 BC), 647, pl. 36 (style 1, subgroup B).
pParis Louvre N. 3272, $t_{3}-h \_b b s / t 3-(w)-g s ̌$. Fragmentary state.

Déveria, 1874: 114-115 (III, 88); Seeber, 1976: 225 (60); Bellion, 1987: 215.

pParis Louvre N. 3295, $p 3$-di-nt. Damaged image. Déveria, 1881: 102 (III. 68); Bellion, 1987: 217; Mosher, 1990: 113-114, 648, pl. 36 (style 1, subgroup B).

pSydney R 87 a, b, c, d, e (University of Sydney, Nicholson Museum, scene of lakes in fragment d). Extra source: pSydney R 85. Fragmentary state.

Coenen, 2006: 83-84 (Totenbuch-Projekt reference).

pTurin 1834, $t 3-k 3 \check{s} t / t 3-w g \check{s}$. Good state of preservation.

Seeber, 1976: 227 (102); Bellion, 1987: 280, dates it between the 26th Dynasty and Ptolemaic Period.

pTurin 1835, $p 3-d i-m n w$. Good state of preservation.

Seeber, 1976: 227 (103); Bellion, 1987: 280, dates it between the 26th Dynasty and Ptolemaic Period.

pZagreb 600 (Archeoloski Musej, Baron von Soller collection), $p 3-d i-{ }^{-} \breve{S} 3-i h w t$. Fragmentary state.

\section{Other Media}

M. Aberdeen ABDUA $23552+\mathbf{5 6 0 4 0}+\mathbf{5 6 0 4 1}+\mathbf{8 4 0 7 0}$ $+84071+84072+84074+84105+84145+$ 84149 (Marischal Museum), ns-ist, [Gurob]. Extra sources: M. Berlin P. 3136, M. London UC 32383 + UC 32407 + UC 55944, M. Philadelphia 
E. 435 B, M. Uppsala VM MB $123+212+229$. Fragmentary state.

Curtis; Kockelmann; Munro, 2005: 60, Nr. 23; 65,72 , fig. 8 .

M. Aberdeen ABDUa $23542+23546+23554+$ $\mathbf{5 6 0 2 6}+\mathbf{5 6 0 3 7}+\mathbf{8 4 1 0 0}+\mathbf{8 4 1 0 1}+\mathbf{8 4 1 8 8}+$ 84195, $d d-h r$, [Saqqara?]. Extra sources: M. Brooklyn Box 19, no $16+24+26+31$, M. Berlin without number $(24)+(25)$, M. Bologna KS 2009 a, M. Boston without number [5] + [7], M. Uppsala VM MB $106+188$ (bis) +280 . Fragmentary state.

Curtis; Kockelmann; Munro, 2005: 63, Nr. 40.

M. Aberdeen ABDuA 84041.1, hry / hryt, unknown provenance. Fragmentary state.

Curtis; Kockelmann; Munro, 2005: 63, Nr. 47.

M. Aberdeen ABDUA $23213+23214$, unknown provenance. Fragmentary state.

M. Aberdeen ABDUA $84216+84274$, unknown provenance. Fragmentary state.

M. Boston MFA 59.1070, $h p-m n h$, Gurob. Extra sources: M. Heidelberg Ä. I. 1931, M. Philadelphia E. 431, M. New York MMA OC 3570. Good state of preservation.

D’Auria; et al., 1988: 226-227 (181).

[ 76 ] M. Los Angeles 83. AI. 47. 1. 4 (The J. Paul Getty Museum), $p 3$-di-wsir, unknown provenance. Extra sources: M. London BM 10074, 5-7, M. Los Angeles 83. AI. 47.11-6, M. Mailand E. 0.9.40453, M. Unknown location a) -e). Good state of preservation.

M. Los Angeles 83. AI. 47. 2. 3, $p 3$-di-wsir, unknown provenance. Extra sources: M. London BM 10074, 1-4, M. Los Angeles 83. AI. 47. 2. 1-4, M. Unknown location, M. private collection. Good state of preservation.

M. Paris Louvre N $3138+\mathbf{3 0 5 8}$, wnn-nfr, [Memphis]. Extra sources: M. Brooklyn Box 19, nos. $1,3,6,7,18,21-23$, Box 20, no. 5, Box 21, no. 4, Box 22, nos. 4, 6, 9, 11, 12, 14, 15, 25, 26. Good state of preservation.

Déveria, 1874: 96-97, Nr. 59-60; Ziegler, 1979: 251-257, pls. 5-8; Bellion, 1987: 204.

M. Vienna ÄS 3848, $d d$-b3stt-iw-f- ${ }^{\top} h h$, unknown provenance. Good state of preservation.

Seipel, C. (1993): Götter, Menschen, Pharaonen, Speyer: 310-311, Nr. 252, Abb. (Totenbuch-Projekt reference).

M. Hildesheim LH 8, $h r-s-n-f$. Good state of preservation.

M. Simonian Private Collection 1 (g, 1-2), mr-iti-s, [Heracleopolis Magna]. Fragmentary state.

Papyri and mummy bandages in which only a part of the vignette of chapter 17 of the BD is preserved but might have included the scene of the Heracleopolitan lakes:

pBerlin P. 3064 A-B, t3-šrt-mhyt, bought in Akhmin.

Kaplony-Heckel: 33 (Kat. Nr. 47).

pBerlin P. 3159 A-D, $t 3$-tmi / tmt, 4th century BC, [Thebes].

Kaplony-Heckel: 44 (Kat. Nr. 84); Seeber, 1976: 222 (14); Bellion, 1987: 33.

pCairo JE 97249, Papyrus 23, $t 3-n f r$, Thebes, Assassif.

pCopenhagen Carlsberg 201, hrw, unknown provenance. 
pFrankfurt 1652 c, Liebieghaus, twt(w), Akhmin.

Burkard, G. (1993): Liebieghaus. Ägyptische Bildwerke III: 254-285, Kat Nr. 62 (TotenbuchProjekt reference); Mosher, 2001: 6 n. 6 and 7, 29, fig. 4.

pGerlach, private collection Siegfried Gerlach,

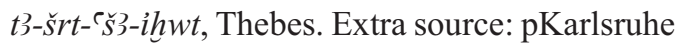
$\mathrm{H}$ 531. The identification of the vignette of chapter 17 of the BD is doubtful.

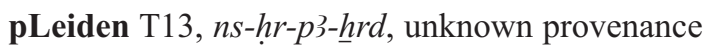

Seeber, 1976: 224 (31); Bellion, 1987: 178, dates it between the 26th Dynasty and Ptolemaic period; Coenen, 1999: 73.

pLeiden T18, unknown provenance. The lower half of the papyrus is lost and the rest is too damaged to distinguish the lakes.

Coenen, 1999: 74.

pLondon BM 9908, $t 3$-šrt-(nt)-mnw, [Thebes]. The papyrus seems to have been split (torn?).

Quirke, 1993: 64 (248).

pLondon BM 9951, $m w t$-ir-di-s, [Thebes]. Extra source: pLondon BM 9944.

Quirke, 1993: 45 (117).

pLondon BM 75044, ns-rri i/ rriw, Thebes.

pMailand E. 1023, $h r-n f r, 300 \mathrm{BC}$, [Thebes].

Lise, 1979: Nr. 69, Taf. 82-91.

PMainz 103 [a] (Landesmuseum, Prinz Johann GeorgSammlung), ns-pth, unknown provenance. Doubtful image of the lakes in one of the fragments.

Heide, B.; Thiel, A. (eds.) (2004): SammlerPilger-Wegbereiter. Die Sammlung des Prinzes
Johann Georg von Sachsen, Mainz (TotenbuchProjekt reference).

pNew York MMA 66.9.142, unknown provenance.

pOmar Pascha (private collection), actual location unknown, hrw-m-hb, Akhmin. The papyrus is unrolled and though only half of the scene is visible, some of the images seem to be repeated.

Collection de feu Omar Pascha Sultan le Caire, Paris, 1929: Nr. 408, pl. LXVI (Totenbuch-Projekt reference).

pOxford 1885. 397 (Ashmolean Museum), unknown provenance. Extra source: pOxford 1885.447 .

pParis Louvre E. 19340, $d d-h r$, unknown provenance. The papyrus seems to have been split/torn.

pParis Louvre E. 27163 / SN 20, $n s-h r-p 3-r^{r}$, unknown provenance.

pParis Louvre N. 3063, $t 3-n t-h b t$, Ptolemaic or late Ptolemaic, Thebes.

pParis Louvre N. 3086, i־h-ms, [Thebes]. Extra source: pSt Petersburg 2656.

Déveria, 1874: 55-56 (III. 4); Seeber, 1976: 224 (41); Bellion, 1987: 196-197.

pParis Louvre N. 3096 (Musée Charles X), ns-mnw, [Thebes]. Only the text of chapter 17 of the $\mathrm{BD}$ is preserved.

Déveria, 1881: 88 (III. 47); Seeber, 1976: 225 (46), 242; Bellion, 1987: 199, dates it to the 30th Dynasty.

pParis Louvre N. 3207, 3208, 3209, hrw, first half of the 2 nd century $\mathrm{BC}$, unknown provenance.

Déveria, 1881: 70-71 (III. 23); Bellion, 1987: 211. 
pParis Louvre N. 3249, $p 3-d i-h r-p 3-r^{c}$, [Thebes].

Déveria, 1881: 100-101 (III, 66); Seeber, 1976: 225 (59); Bellion, 1987: 214; Mosher, 1990: 109-111, 507 (suggests date between 250 - 200 BC), 648 (group B), pl. 36.

pParis Louvre SN (Ref AE029481), hrr, unknown provenance.

pPhiladelphia E. 17319 (University of Pennsylvania Museum), $t 3$-dit-hrww-p3-hrd / $t 3$-šrit-hrw, unknown provenance.

pPhiladelphia 83 - 1 - 1 (a- i), hrí-(ib), Ptolemaic Period, unknown provenance. Extra sources: pNew York Publ. Lib, Ms. n. 1, pPhiladelphia 83-1-1-(k).

Coenen, M., 2002: in BES 16: 51-57, pl. 6, dates it to the 2 nd-1 st century BC and assigns it a Theban origin (Totenbuch-Projekt reference).

pToronto ROM 978 x 43.1 (Royal Ontario Museum), imn-m- $h 3 t$, unknown provenance.

pUnknown location, $n h m-s-r^{\top} t-t 3 w y$, [Thebes]. Extra sources: pSotheby's Auction (London 18th May 1981), Nr. 282, 283, pAnn Arbor 87.12.4, pUnknown location (Writing \& Lettering in Antiquity, Charles Ede Ltd, 24th-26th October 1989, Nr. 23).

Sotheby's Auction London, 18th May 1981: Nr. 281.

The following mummy bandages:

- From Aberdeen ABDUA collection 1: M. Aberdeen ABDUA $23571+56004+84065+84067+$ 84068, $n f r t-i ̉$, [Memphis?]; from unknown provenance: 2: $25565+\mathbf{8 4 0 5 8}, \ldots d d-t w n-f h r w-w \underline{d}$,
$3: 56067+84040+84045+84049+84013$, 3rs$y n 3 t, \mathbf{4}: \mathbf{8 4 1 2 4 , 5 : 8 4 0 9 9}$ (may be part of the previous one), 6: 84041.2, 7: $23202+23210+23211$, 8: 84047, 9: 84150, 10: 84146, 11: 23201, 12: 23268, 13: $23243+84277,14: 23288,15: 23260$, 16: 23584 + 84197, 3st-ršỉ, 17: 84142, $t 3-s ̌ r t-n-$ t3-kri. For the collection see Curtis; Kockelmann; Munro, 2005: 56, n. 49; 57-63.

- From Simonian Private Collection and probable Heracleopolitan origin 18: M. Simonian 1 (b), $m r-i t i-s$, 19: 2 (d) and 2 (e), $h r-s-n-f, 20: 3$ (a) and 3 (d), ${ }^{\top} n h-m-m 3{ }^{\top} t$.

- From London Museums: 21: M. London BM $10144+10147+10148+10149$, ${ }^{`} n h-h p w$, unknown provenance 22: M. London UC 32449 $+\mathbf{3 2 4 5 0}+\mathbf{3 2 4 5 1}+\mathbf{3 2 4 5 2}$, hrw-s3-3st, [Saqqara]; 23: M. London UC 32386 + UC 32837, 1-2 + M. Philadelphia E 424 A + B (University of Pennsylvania Museum of Archaeology and Antropology), ini-hrt, Gurob.

- From Vienna collections: 24: M. Vindob. Aeg. 8336, nht-wrt, unknown provenance; 25: M. Vindob. Aeg. 8363, 8364, 8366, 8367, $\underline{d} d-h r r$, unknown provenance.

$\neg$ From the rest of collections: 26: M. Florence Inv. 3681 [a] - [aj], ' $n h-h p w / h p w$, [Memphis]; 27: M. Leiden AED 106 a-l ("T70 a-l"), Rijksmuseum van Oudheden, $h r-{ }^{-} n h \underline{h} d d$ tw $n-s$

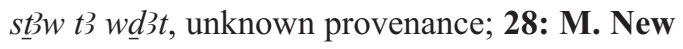
York MMA X 457; 29: M. Oxford Ms. Egypt c. 6 (p) (Bodleian Library), a) $p 3-d i-b{ }^{c} s t t$ b) $\underline{t} 3 \hat{i}-$ $m w$; 30: M. Rouen 378 (Musée des Antiquités de Sein-Maritime); 31: M. Sydney R. 394, gmw-hpw / ' $n h$ - hpw w unknown provenance; 32: M. Toronto ROM 909.80.551 + 909.80.552, [šmti], [Gurob]; 33: M. Uppsala O. Nr, ' $n h$ $w r-m r$, [Saqqara]; 34: M. Vatican Inv. 48820, 1-4, hpw-[-], [Memphis?]. 


\section{KeY TO THE TABLES}

The descriptive categories of the tables on which the analysis of each document is based include the following issues:

Number of Inventory ( $\mathbf{N}^{\circ}$ Inv.) - following the nomenclature in the Archive of the Totenbuch-Projekt at Bonn, but toponyms translated into English. "p" stands for papyrus; "M" for mummy bandage; TT, KV and QV for Theban Tombs, Valley of the Kings and Valley of the Queens respectively.

Provenance - place of origin, when precisely known (if inferred by titles or stylistic features, given between square brackets; otherwise left blank).

\section{Figure (fig.)}

A 1st figure (to number figures we follow their orientation in the document).

$\mathrm{B}$ 2nd figure.

$\mathrm{X}$ Owing to the loss of one figure, we cannot determine if the remaining character is the 1 st or 2 nd one.

$\rightarrow$ Figure's orientation - towards the right.

$\leftarrow$ Figure's orientation - towards the left.

- Cannot be determined with certainty (due to damage or loss).

$\varnothing$ Omitted.

\section{Type of figure (type of fig.)}

1 Fecundity figure.

2 Male figure bearing a feature of divinity (curved beard or bull tail) 1 .

3 Male figure without feature of divinity.

4 Female figure.

- Cannot be determined with certainty (due to damage or loss).

$\varnothing$ Omitted.

\section{Body posture}

1 Standing with arms stretched in different directions.

2 Seated with arms stretched in the same direc- tion. In types 2, 3 and 4 the object above which the figure seats -reed mat, chapel...will be recorded; if no object is mentioned, he/she lays over the groundline.

3 Seated with arms stretched in the same direction and holding an object.

4 Seated with arms stretched in different directions.

- Cannot be determined with certainty (due to damage or loss).

$\varnothing$ Omitted.

Wig — Two features are outlined: colour; presence of ornaments. In the boxes the colours used will be shortened thus: B (for blue), K (black), B/G (blue-greenish), D (dark), G (green), L (light), O (orange), R (red), Y (yellow). If L or D are placed before the capital letter, they add information about shade (e.g. LB stands for light blue, DG for dark green). If document was checked through black and white pictures, colour could only be described as dark (D) / light (L), darker than A/B (abbreviated $\mathrm{D}>\mathrm{A}$ or $\mathrm{D}>\mathrm{B}$ ) or lighter than $\mathrm{A} / \mathrm{B}$ $(\mathrm{L}>\mathrm{A}$ or $\mathrm{L}>\mathrm{B}$ ). Question mark (?) means that no colour is indicated in the publication and outlined $(\mathrm{Ou})$ that the profile of figures is drawn with a black line. Indications of typology and orientation of ornaments are supplied:

- Vegetal ornament (clumps of papyri or

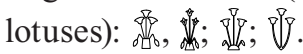

- Stems and branches (renpet) with one or several notches: $: \mathbb{i} ; ;\}$

Body - Two features are outlined: colour (applying above criteria); presence of waves.

\section{Attitude}

Protect.

Offer.

D Embrace.

1. The presence of lacunae blurring significant features may prevent recognizing which is the type of figure depicted. In this case, two categories are indicated (e.g. 1 or 2?). 
$\simeq$ Grasp (clenched fist).

- Cannot be determined with certainty (due to damage or loss).

$\varnothing$ Omitted.

\section{Object protected or offered (obj. prot / offer.) -} Indications of typology and orientation are presented. When objects are aligned, the figure is placed between them acting as an axis of symmetry. If superimposed, the arm of the figure usually lies between them, but if both are placed under it an exclamation mark (!) will be used.

- Eye: wide range of types; orientated; sometimes eyebrows and eyelashes depicted; may appear inside ovals or circles and over pedestals or platforms. A*-sign beside it indicates that the vertical appendix hanging in the feathered and wdjat eyes has been omitted.

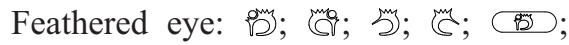

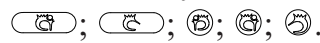

Wdjat eye: 采; 栗; 原; (1).

Simple eye: $\infty ; \infty$; $\infty$; $\infty$; $\infty$;

Simplified eye (profile outlined): $\rightleftharpoons$.

- Empty ovals / circles: $\hookrightarrow$; $\circ$; 0 .

$\neg$ Lakes: of varied shapes; sometimes with waves inside. $\square$; bination of eyes and lakes will be indicated thus: $\frac{m}{2} ;$.

$\neg$ Doors: of varied shapes; leaves opened or closed: $\square$; س. Combination of doors and

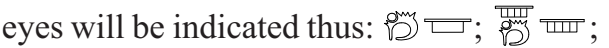
$\rightleftarrows \ldots$

$\neg$ Table / offering table: usually a quadrangular or rectangular object resting over the ground on its short or long side: $\mathbb{\|}$; 四; $\square$; $\square$; sometimes depicted as a matt with piled offerings

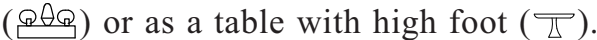
Combination of tables with lakes and doors will be indicated thus : $\vec{\square} ; \overrightarrow{\mathbb{U}} ; \vec{\nabla}$...

$\neg$ Shen-ring: 으.

$\neg$ Omitted: $\varnothing$.

$\neg$ Lost or damaged: - .

Name of figure or lake (name fig / lake) - if recorded, these will be transcribed.

Object held (obj. held) - Indications of typology and orientation are supplied:

- Vegetal: renpet-stem with one or several

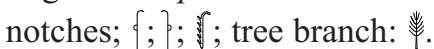

$\neg$ Oar (?): ?.

- Attributes of power and divinity: was-staff १; ankh-sign f.

- Heb-bowl: $\otimes$.

$\neg$ Omitted: $\varnothing$.

$\neg \quad$ Lost or damaged: -. 
TABle I: PAPyri From the 19Th Dynasty

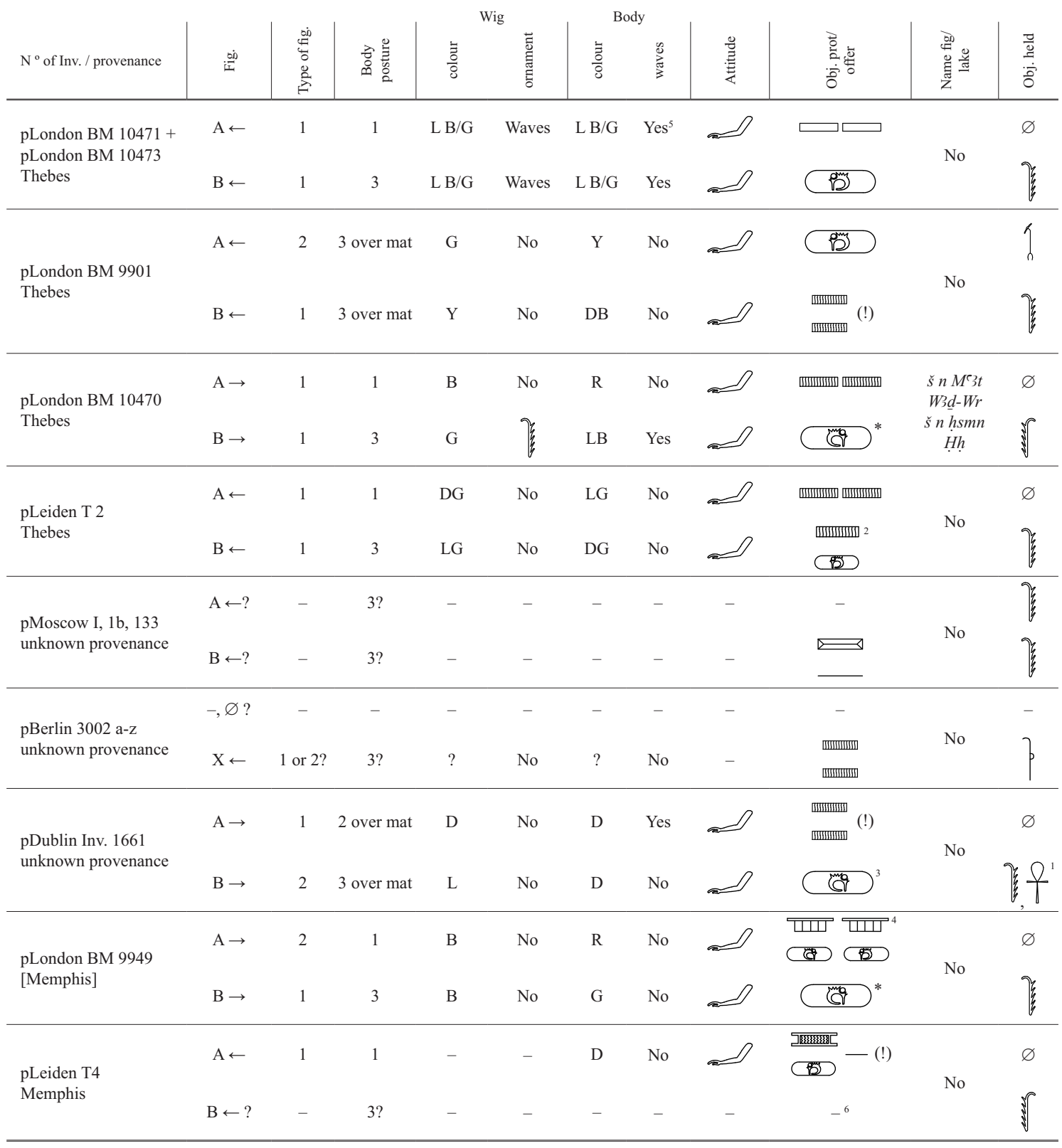

1. The two objects are held in the same hand.

2. The total number of lakes depicted in the vignette amounts to two. The pond placed in the middle of the characters is protected by both standing and seated figures at the same time.

3. The eyebrow continues at the external corner of the eye.

4. An outstanding exception, since the two feathered eyes inside ovals are depicted facing each other. The arms of the standing figure appear between two doors above and two eyes below. The number of eyes amounts to two, the one on the left side of the vignette being protected by both figures at once.

5. While both figures show horizontal waves in their body, face and wig, the standing male has the face covered with vertical ones.

6. The feathered eye inside the oval rests over a pedestal crowned with a cyma. The shape of the lake is close to a water channel. Given the similarity with pLondon BM 9949, we can hint at a symmetrical composition with another eye and lake on the other side, but the former orientated in the opposite direction. 
TABLE II: RAMESSIDE TOMBS

\begin{tabular}{|c|c|c|c|c|c|c|c|c|c|c|c|}
\hline \multirow{2}{*}{$\begin{array}{l}\text { Tomb / funerary object } \\
\text { place of origin }\end{array}$} & \multicolumn{5}{|c|}{ Wig } & \multicolumn{2}{|c|}{ Body } & \multirow[b]{2}{*}{ 童 } & \multirow[b]{2}{*}{ 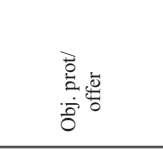 } & \multirow[b]{2}{*}{ 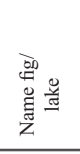 } & \multirow[b]{2}{*}{$\begin{array}{l}\frac{\pi}{2} \\
\stackrel{0}{\circ}\end{array}$} \\
\hline & 宝 & 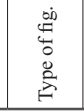 & 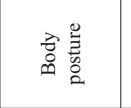 & $\frac{\overline{0}}{8}$ & 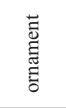 & $\frac{\bar{z}}{8}$ & 总 & & & & \\
\hline \multirow{2}{*}{$\begin{array}{l}\text { Cenotaph of Sety I } \\
\text { Abydos }\end{array}$} & $\mathrm{A} \rightarrow$ & 1 & 3 & $?$ & No & $?$ & No & $\simeq$ & 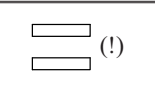 & \multirow{2}{*}{ No } & $\oint$ \\
\hline & $\mathrm{B} \rightarrow$ & 1 & 3 & $?$ & No & $?$ & No & $\approx$ & pm & & 0 \\
\hline \multirow[b]{2}{*}{$\begin{array}{l}\text { KV 10, left wall, } \\
\text { Valley of the Kings }{ }^{16}\end{array}$} & $\mathrm{~A} \leftarrow$ & 1 & 1 & $\mathrm{Ou}^{11}$ & No & $\mathrm{Ou}$ & No & $\cong$ & $\square \square$ & \multirow[b]{2}{*}{ No } & $\varnothing$ \\
\hline & $\mathrm{B} \leftarrow$ & $3 ?^{14}$ & 3 & $\mathrm{Ou}$ & No & $\mathrm{Ou}$ & No & $\approx$ & (1) & & 度 \\
\hline \multirow{2}{*}{$\begin{array}{l}\text { KV 10, right wall, } \\
\text { Valley of the Kings }{ }^{16}\end{array}$} & $\mathrm{~A} \rightarrow$ & 1 & 3 & B & No & $\mathrm{Ou}$ & No & $\approx$ & (98) & \multirow{2}{*}{ No } & $\sqrt[5]{5}$ \\
\hline & $\mathrm{B} \rightarrow$ & 1 & $1^{13}$ & $\mathrm{Ou}^{12}$ & No & $\mathrm{Ou}$ & No & $\cong$ & $\square \square$ & & $\varnothing$ \\
\hline \multirow{2}{*}{$\begin{array}{l}\text { QV } 66 \\
\text { Valley of the Queens }\end{array}$} & $\mathrm{A} \rightarrow$ & 1 & 1 & $\mathrm{Y} / \mathrm{R}$ & No & $\mathrm{DB}$ & No & $\cong$ & 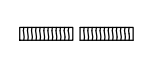 & \multirow{2}{*}{ No } & $\varnothing$ \\
\hline & $\mathrm{B} \rightarrow$ & 1 & 3 & $\mathrm{LB} / \mathrm{G}$ & No & $\mathrm{DB}$ & No & $\approx$ & $\stackrel{m a}{9}$ & & $\sqrt[5]{ }$ \\
\hline \multirow{2}{*}{$\begin{array}{l}\text { TT } 32 \\
\text { Khokha }\end{array}$} & $\mathrm{X} \rightarrow$ & 1 or $3 ?$ & $4 ?$ & $?$ & No & B & No & 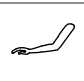 & 血血血 & \multirow[t]{2}{*}{$\begin{array}{l}W 3 d- \\
W r\end{array}$} & $\varnothing$ \\
\hline &,$- \varnothing ?$ & - & - & - & - & - & - & - & - & & - \\
\hline \multirow{2}{*}{$\begin{array}{l}\text { TT } 135 \\
\text { Gurna }\end{array}$} & $\mathrm{X} \rightarrow$ & 1 & 2 & ? & ot & $?$ & No & 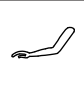 & ma & \multirow{2}{*}{$\mathrm{No}^{8}$} & $\varnothing$ \\
\hline &,$- \varnothing ?^{15}$ & - & - & - & - & - & - & - & - & & - \\
\hline \multirow{2}{*}{$\begin{array}{l}\text { TT } 265 \\
\text { Deir el-Medina }\end{array}$} & $\mathrm{A} \leftarrow$ & 1 & 1 & $\mathrm{~L}$ & No & $\mathrm{L} ?$ & No & 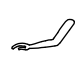 & $\varpi \sqsubset$ & \multirow{2}{*}{ No } & $\varnothing$ \\
\hline & $\mathrm{B} \leftarrow$ & 1 & 3 & D & No & G & No & $\cong$ & bie & & \} \\
\hline \multirow{2}{*}{$\begin{array}{l}\text { JdE } 27302 \\
\text { Deir el-Medina }\end{array}$} & $\mathrm{A} \leftarrow$ & 1 & 1 & B & No & LG & No & $\cong$ & 밈m & \multirow{2}{*}{ No } & $\varnothing$ \\
\hline & $\mathrm{B} \leftarrow$ & 1 & 3 & $\mathrm{LG}^{10}$ & No & DG & No & $\approx$ & bin & & 谣度 \\
\hline \multirow{2}{*}{$\begin{array}{l}\text { Tomb of 'Ini-hr(t)-ms } \\
\text { (Anhurmose) } \\
\text { El-Mashayikh }\end{array}$} & $\mathrm{A} \rightarrow$ & 2 & 2 over stand & $?$ & $\oint$ & $?$ & No & $\cong$ & $\square$ & $H h$ & $\varnothing$ \\
\hline & $\mathrm{B} \rightarrow$ & 2 & 1 & $?$ & No & $?$ & No & $\cong$ & $\square \square \square^{17}$ & $\begin{array}{c}W 3 \underline{d}- \\
W r\end{array}$ & $\varnothing$ \\
\hline
\end{tabular}

7. The second figure holds two branches in his hands.

8. Interspersed between the figures are columns of text which were left blank, but were probably intended to record their names (Baines, 1985: 326).

9. Though the first object is lost, it could have been another lake due to the similarity in pattern to other scenes guided by an axis of symmetry as in pLondon BM 9949 (see table I).

10. The colour of this wig is discussed by Baines, 1985: 381, n. f.

11. The building and decoration of the tomb was not finished, pits and chambers (among which the sarcophagus chamber) being left without digging. At the outset, the tomb was decorated up to the hypostyle hall for king Amenmessu with scenes from the Letany of Re and the Duat, following the pattern of Merneptah's tomb (KV 8). When re-used for queens Takhat and Bakturel of the 20th Dynasty, the walls of the outer corridors, pit chamber and hypostyle hall .../... 
TABle III: PAPYRI From the 21th Dynasty

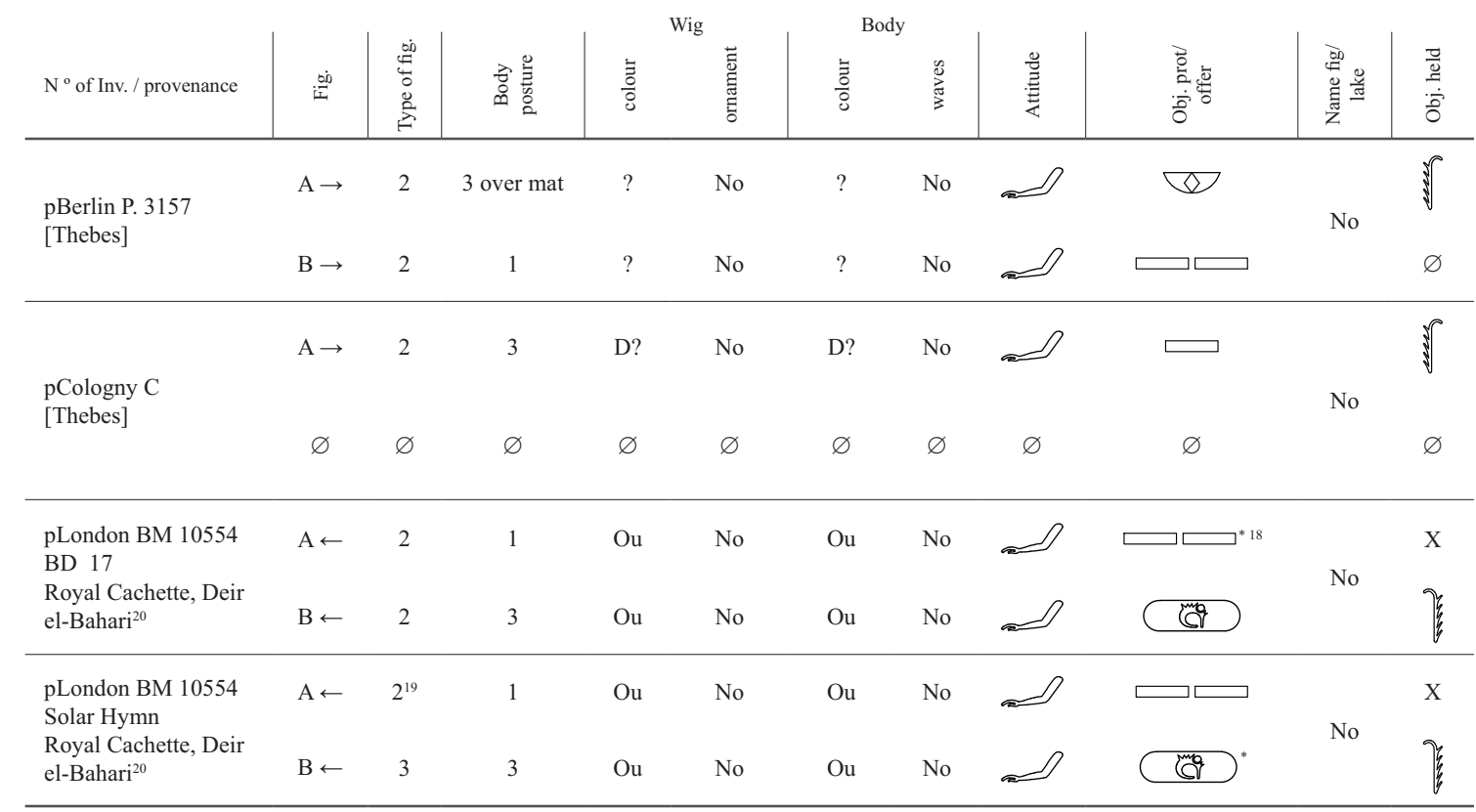

were covered with plaster and painted with images from the Book of the Dead (Reeves; Wilkinson, 1999: 150-151). Many figures and objects were not filled with colour, and in the scene of the lakes only these ones were painted green.

12. Lefébure highlights the absence of colour of these figures, of which only small details such as wigs, bracelets and so on were painted (1889: pl. 56).

13. Only case where the two figures are not placed upon the same groundline, because the standing one is larger and breaks the plane.

14. The figure looks somehow asexual, as far as no clear masculine or feminine traits are highlighted.

15. The image reproduced by Baines only shows a male figure with raised arm in a gesture of protection towards a feathered eye inside an oval and of adoration towards an uraeus (Baines, 1985: 326, fig. 185). The author hints at a symmetric composition, with a similar figure at the opposite side. Since the whole scene could not be checked, we remain cautious, because it would be the only instance depicting two figures facing each other in an attitude of praise, instead of being aligned in the same direction.

16. Scene represented twice in opposite walls. Although both adhere to the same scheme, the work of two different hands is recognizable and a closer attention to small details is noticeable in the right wall.

17. The depiction of three lakes is exceptional among our sources, the only known parallel being pColonia Aeg. 10207 dated in the 26th Dynasty.

18. By placing the oval+eye below the right lake, the standing figure seems to protect both objects with his gesture.

19. From the kilt hangs the tail of a bull, an element linked with gods and the king, but the figure lacks the distinctive curved, divine beard.

20. It is remarkable that the vignette has been represented twice with chapter BD 17 and a solar hymn. The images are positioned behind the text in this papyrus and some scenes (such as those of chapters 17 and 125) were therefore duplicated-Niwinski, 1989: 155-157. Though both follow the same pattern, the differences in style of the figures may be ascribed to the workmanship of two scribes. 
TABle IV: PAPYRi From the 26th Dynasty

\begin{tabular}{|c|c|c|c|c|c|c|c|c|c|c|c|}
\hline \multirow[b]{2}{*}{$\mathrm{N}^{\circ}$ of Inv. / provenance } & \multicolumn{5}{|c|}{ Wig } & \multicolumn{2}{|c|}{ Body } & \multirow[b]{2}{*}{ 总 } & \multirow[b]{2}{*}{ 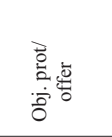 } & \multirow[b]{2}{*}{ 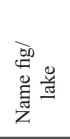 } & \multirow[b]{2}{*}{$\begin{array}{l}\frac{\pi}{2} \\
\dot{0} \\
0\end{array}$} \\
\hline & 竞 & 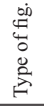 & 突产 & $\frac{\overline{0}}{8}$ & 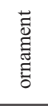 & $\frac{\bar{c}}{8}$ & 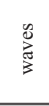 & & & & \\
\hline \multirow{2}{*}{$\begin{array}{l}\text { pCairo S.R. IV } 692 \\
\text { Thebes } \int\end{array}$} & $\mathrm{A} \leftarrow$ & 4 & $2 ?$ & $\mathrm{~B}$ & No & $\mathrm{Y}$ & No & $\simeq$ ? & - & \multirow{2}{*}{ No } & $\varnothing$ \\
\hline & $\mathrm{B} \leftarrow$ & 4 & 2 & B & No & $\mathrm{Y}$ & No & $\cong$ & (im) & & $\varnothing$ \\
\hline \multirow{2}{*}{$\begin{array}{l}\text { pTheben / Ramesseum } \\
\text { (1) } \\
\text { Ramesseum }\end{array}$} & $\mathrm{A} \leftarrow$ & 1 & 2 & $\mathrm{~K}$ & No & B & No & $\cong$ & 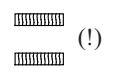 & \multirow[b]{2}{*}{ No } & $\varnothing$ \\
\hline & $\mathrm{B} \leftarrow$ & 1 & 3 & K & No & B & No & $\cong$ & & & p \\
\hline \multirow{2}{*}{$\begin{array}{l}\text { pColonia Aeg. } 10207 \\
\text { Heracleopolis Magna }\end{array}$} & $\mathrm{A} \leftarrow$ & 1 & 2 & $?$ & - & DG & No & $\cong$ & $\square$ & \multirow[b]{2}{*}{ No } & $\varnothing$ \\
\hline & $\mathrm{B} \leftarrow$ & 1 & 3 & $?$ & - & $\mathrm{R}$ & No & $\approx$ & $\varlimsup^{21}$ & & $\eta$ \\
\hline \multirow{2}{*}{$\begin{array}{l}\text { pLondon BM } 10558 \\
\text { [Memphis] }\end{array}$} & $\mathrm{A} \leftarrow$ & 1 & 3 & $\mathrm{Ou}$ & No & $\mathrm{Ou}$ & No & $\cong$ & 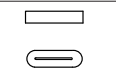 & \multirow{2}{*}{ No } & 便 \\
\hline & $\mathrm{B} \leftarrow$ & 1 & 3 & $\mathrm{Ou}$ & No & $\mathrm{Ou}$ & No & $\cong$ & ) & & 妾 \\
\hline \multirow{2}{*}{$\begin{array}{l}\text { pParis Louvre N. } 3091 \\
\text { Memphis }\end{array}$} & $\mathrm{A} \leftarrow$ & 1 & $2 ?$ & $\mathrm{D}$ & No & $?$ & No & - & - & \multirow{2}{*}{ No } & $\varnothing$ \\
\hline & $\mathrm{B} \leftarrow$ & 1 & $2 ?$ & $\mathrm{D}$ & No & $?$ & No & - & - & & - \\
\hline
\end{tabular}

21. The only parallel for the depiction of three lakes is the Ramesside tomb of 'Ini-hr(t)-ms (Anhurmose). We may recall that only two lakes are mentioned in the funerary formula linked with this illustration. 
Table V: Papyri from the 30th Dynasty and Early Ptolemaic Period

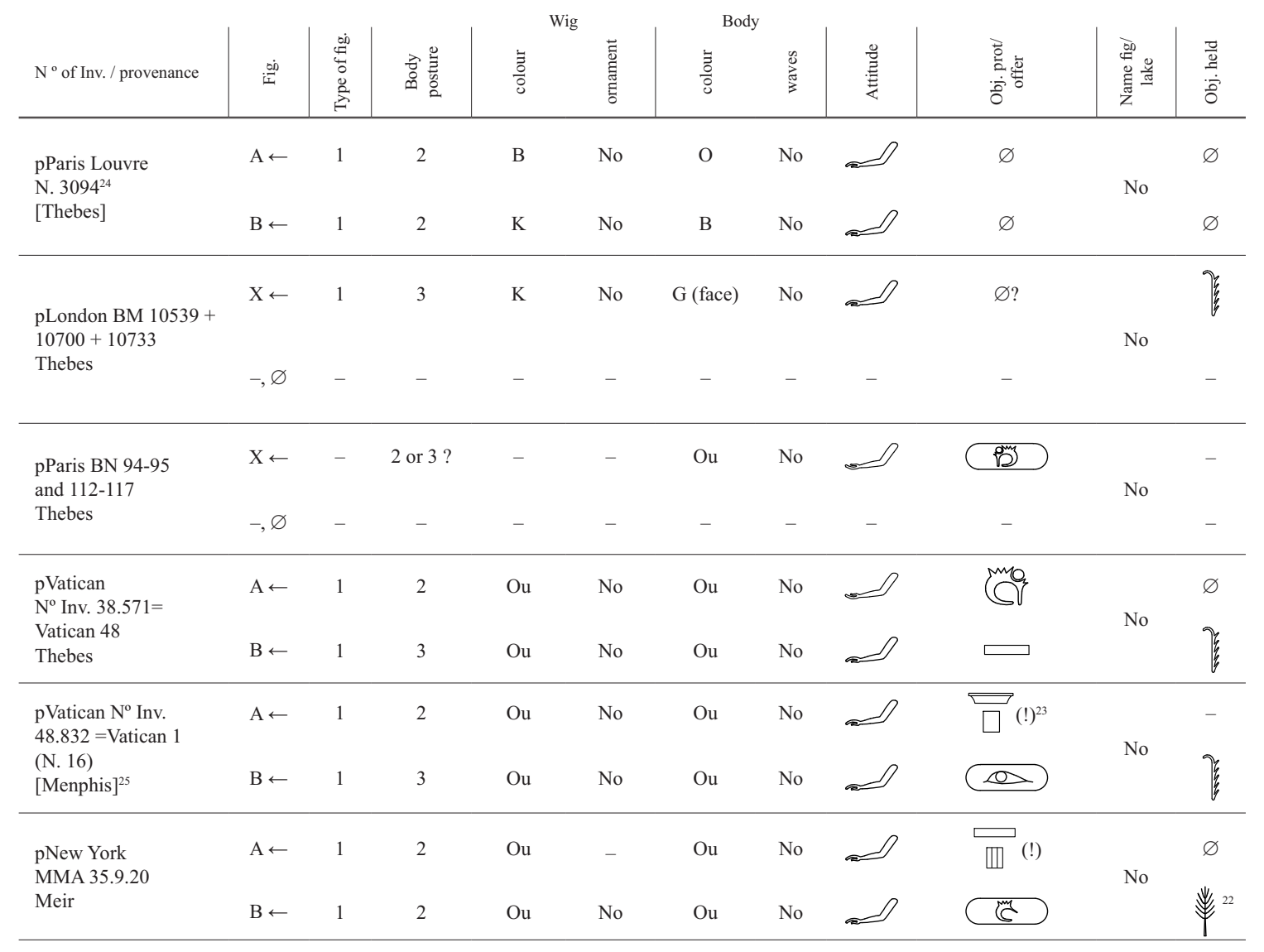

22. The branch is not held by the second figure, but projects instead from behind the feathered eye.

23. The two superimposed objects are partially hidden behind a high structure (a chapel) depicted to the left of figure A. They seem to be either a door and a lake or two pools with different shapes (rectangular- and cube-like). As the bottom object lays on the ground, it could be regarded as a type of table.

24. Charrot dates this document between the Late and Ptolemaic Periods -2002: 152-171 ( ${ }^{\circ} 73$ ).

25. Dates assigned to this papyrus range between the end of the 26th Dynasty and the last native dynasties (Gasse heads for the latter-1993: 35-36 ( $\left.{ }^{\circ} 23\right)$; ead., 2001: 13-14). 
Table VI: Ptolemaic Papyri, Thebes

\begin{tabular}{|c|c|c|c|c|c|c|c|c|c|c|c|}
\hline \multirow{2}{*}{$\mathrm{N}^{\circ}$ of Inv./ provenance } & \multicolumn{5}{|c|}{ Wig } & \multicolumn{2}{|c|}{ Body } & \multirow[b]{2}{*}{ 竞 } & \multirow[b]{2}{*}{ 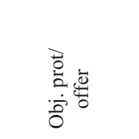 } & \multirow[b]{2}{*}{ 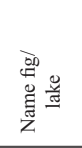 } & \multirow[b]{2}{*}{$\begin{array}{l}\frac{7}{0} \\
\frac{0}{0}\end{array}$} \\
\hline & 宝 & 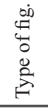 & 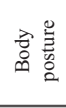 & $\frac{\overline{0}}{8}$ & 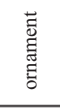 & $\frac{\bar{z}}{8}$ & 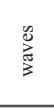 & & & & \\
\hline \multirow{2}{*}{$\begin{array}{l}\text { pAberdeen ABDUA } \\
84023,1-7 \\
{[\text { Thebes }]^{30}}\end{array}$} & $\mathrm{~A} \leftarrow$ & 1 & 3 & B & No & G & No & $\approx$ & 0 & \multirow[t]{2}{*}{ No } & 展 \\
\hline & $\mathrm{B} \leftarrow$ & 1 & 3 & K & No & B & No & $\approx$ & $\mathrm{O}^{26}$ & & 展 \\
\hline \multirow{2}{*}{$\begin{array}{l}\text { pBerlin P. } 3158 \text { A-G } \\
{[\text { Thebes }]^{30}}\end{array}$} & $\mathrm{~A} \leftarrow$ & 3 & $2 ?$ & $\mathrm{~L}>\mathrm{B}$ & No & $\mathrm{L}>\mathrm{B}$ & No & $\approx$ & -27 & \multirow{2}{*}{ No } & $\varnothing ?$ \\
\hline & $\mathrm{B} \leftarrow$ & 1 & 3 & $\mathrm{D}>\mathrm{A}$ & No & $\mathrm{D}>\mathrm{A}$ & No & $\approx$ & $\varnothing$ & & \\
\hline \multirow{2}{*}{$\begin{array}{l}\text { pSt Petersburg } 3531 \\
\text { [Thebes] }\end{array}$} & $\mathrm{A} \leftarrow$ & 1 & 2 & $\mathrm{Ou}$ & No & $\mathrm{Ou}$ & No & $\approx$ & $\square$ & \multirow{2}{*}{ No } & $\varnothing$ \\
\hline & $\mathrm{B} \leftarrow$ & 1 & 2 & $\mathrm{Ou}$ & No & $\mathrm{Ou}$ & No & $\approx$ & (2) & & $\varnothing$ \\
\hline \multirow{2}{*}{$\begin{array}{l}\text { pDetroit } 1988.10 \\
\text { [Thebes] }\end{array}$} & $\mathrm{A} \leftarrow$ & 1 & 2 & $\mathrm{Ou}$ & No & $\mathrm{Ou}$ & No & & $\begin{array}{l}\bar{W} \\
\bar{W}(!)\end{array}$ & \multirow{2}{*}{ No } & $\varnothing$ \\
\hline & $\varnothing$ & $\varnothing$ & $\varnothing$ & $\varnothing$ & $\varnothing$ & $\varnothing$ & $\varnothing$ & $\varnothing$ & $\varnothing$ & & $\varnothing$ \\
\hline \multirow{2}{*}{$\begin{array}{l}\text { pParis BN 1/19 } \\
\text { (pCadet) } \\
\text { Thebes }\end{array}$} & $\mathrm{A} \leftarrow$ & 1 & 2 & LY & No & Y & No & & $\varnothing$ & \multirow[t]{2}{*}{ No } & $\varnothing$ \\
\hline & $\mathrm{B} \leftarrow$ & 1 & 2 & LY & No & $\mathrm{R}$ & No & $\cong$ & ping & & $\varnothing$ \\
\hline \multirow{2}{*}{$\begin{array}{l}\text { pParis BN 24-32 } \\
\text { [Thebes] }\end{array}$} & $\mathrm{A} \leftarrow$ & 2 & 2 & K & No & $\mathrm{D}>\mathrm{B}$ & No & $\approx$ & $\bigodot^{28}$ & \multirow{2}{*}{ No } & $\varnothing$ \\
\hline & $\mathrm{B} \leftarrow$ & 1 & 3 & K & No & $\mathrm{L}>\mathrm{A}$ & No & $\approx$ & $\longrightarrow$ & & \\
\hline \multirow{2}{*}{$\begin{array}{l}\text { pParis Louvre N. } 3129 \\
\text { + E. } 4890 \text { B } \\
\text { [Thebes] }\end{array}$} & $\mathrm{A} \leftarrow$ & 1 & 2 & $\mathrm{Ou}$ & No & $\mathrm{Ou}$ & No & $\approx$ & $\square$ & \multirow[t]{2}{*}{ No } & $\varnothing$ \\
\hline & $\mathrm{B} \leftarrow$ & 1 & 2 & $\mathrm{Ou}$ & No & $\mathrm{Ou}$ & No & $\cong$ & pin & & $\varnothing$ \\
\hline \multirow{2}{*}{$\begin{array}{l}\text { pLondon BM } 10097 \\
\text { [Thebes] }\end{array}$} & $\mathrm{A} \leftarrow$ & 1 & 2 & K & No & $\mathrm{B} / \mathrm{G}$ & No & $\approx$ & $\square^{29}$ & \multirow{2}{*}{ No } & $\varnothing$ \\
\hline & $\mathrm{B} \leftarrow$ & 1 & 2 & $\mathrm{O}$ & No & $\mathrm{R}$ & No & $\cong$ & (10) & & $\varnothing$ \\
\hline \multirow{2}{*}{$\begin{array}{l}\text { pParis Louvre N. } 3152 \\
\text { [Thebes] }\end{array}$} & $\mathrm{A} \leftarrow$ & 1 & 2 & $\mathrm{Ou}$ & No & $\mathrm{Ou}$ & No & $\Omega$ & $\operatorname{mos}^{m}$ & \multirow{2}{*}{ No } & $\varnothing$ \\
\hline & $\mathrm{B} \leftarrow$ & 1 & 3 & $\mathrm{Ou}$ & No & $\mathrm{Ou}$ & No & $\cong$ & $\varnothing$ & & 质 \\
\hline
\end{tabular}

26. The only instance known of a figure holding a branch with the arm in the background is another Ptolemaic papyrus of unknown origin (pChicago OIM 9787). The oval protected with the arm in the foreground has its interior blurred but seems to be empty.

27. The splitting of page $\mathrm{D}$ has resulted in the loss of the object protected by the first figure.

28. The object inside the oval is damaged, but is not similar to any type of eye reviewed so far in the rest of sources.

29. Although the image is not clear, the object protected seems to be a lake.

30. pAberdeen ABDUA 84023. 1-7, pBerlin P. 3158 A-G and pBerlin P. 3159 A-D (the latter could have included the scene of the Herakleopolitan lakes, but it is not preserved) were executed in the same workshop. The images are similar in style, the text is nearly identical and they belong to the same family -father, mother and daugther are the owners respectively. 


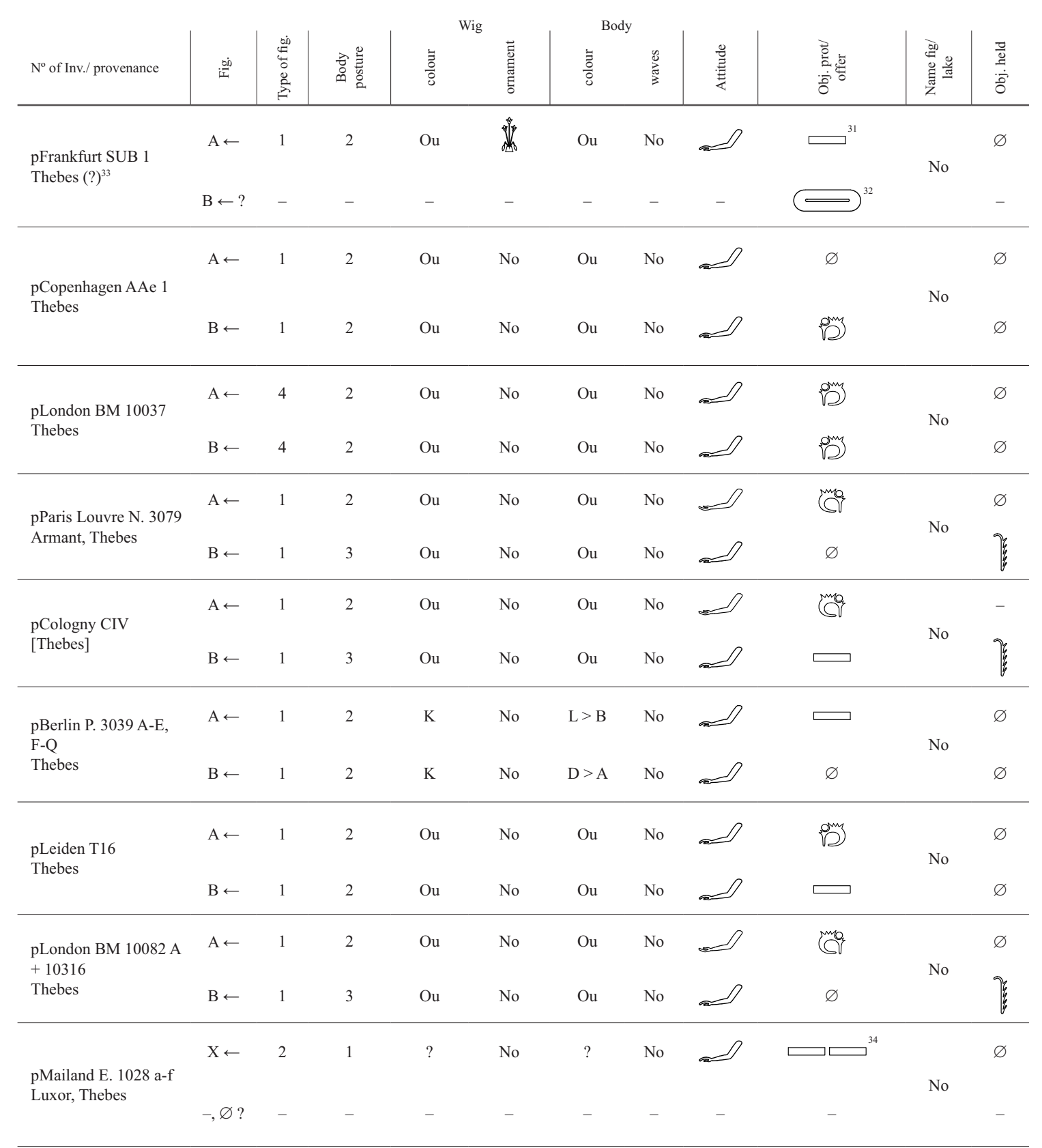

31. The pond is large, rests over the ground and is partially hidden behind the figure.

32. Lacunae in the papyrus prevent the recognition of the type of eye depicted, though it could be of the simple type.

33. The arrangement of texts and vignettes in this papyrus as well as its general formal style points at Memphis as a more probable place of origin than Thebes. Mosher even includes it in his style 2 (1992: 149-151), characterised by a Memphite provenance and an overall formality.

34. The object proctected under the right palm looks like another pond, but the image is damaged on the spot. 


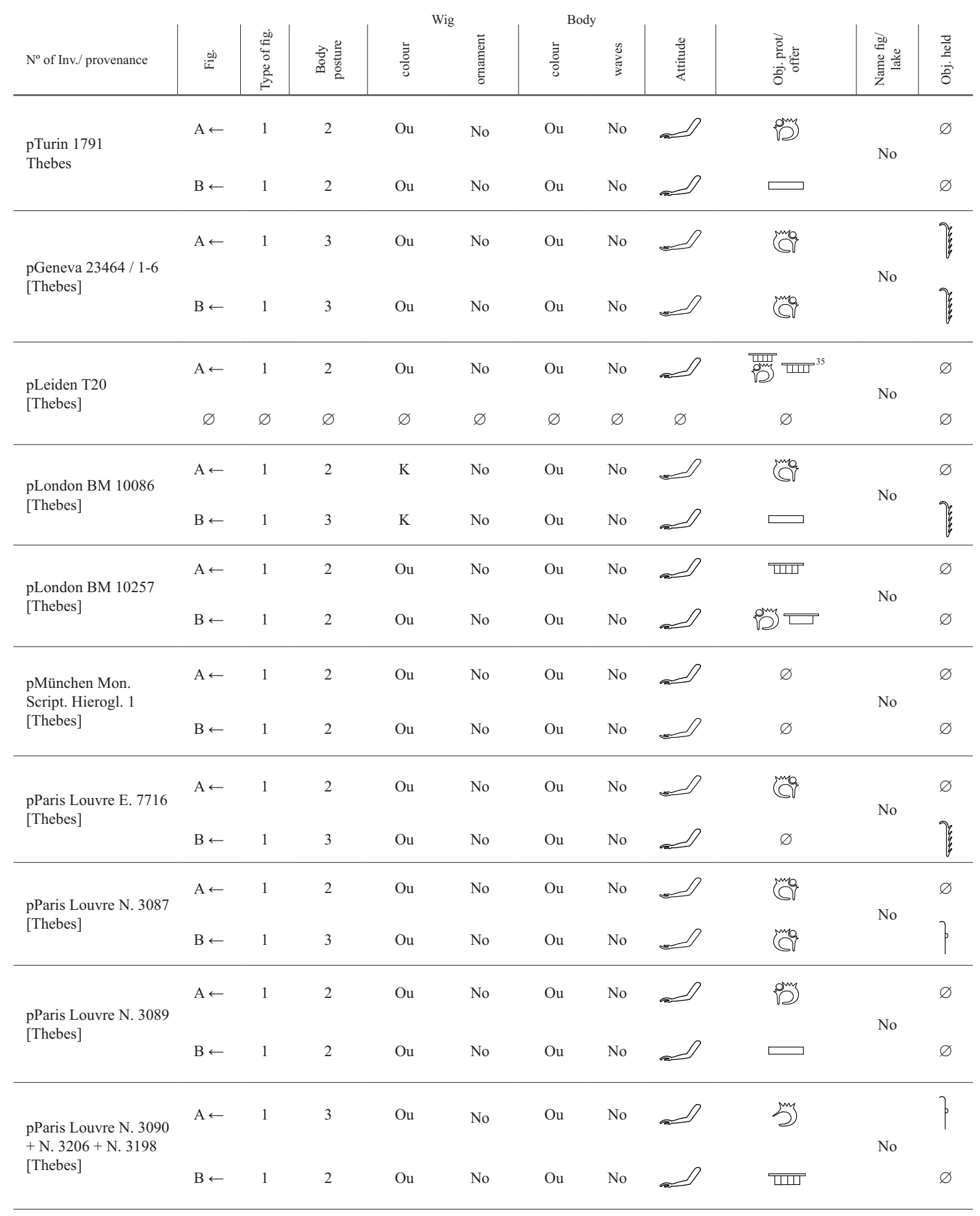

35. The three elements are placed under the palms of the figure. 


\begin{tabular}{|c|c|c|c|c|c|c|c|c|c|c|c|}
\hline \multirow[b]{2}{*}{$\mathrm{N}^{\circ}$ of Inv./ provenance } & \multicolumn{5}{|c|}{ Wig } & \multicolumn{2}{|c|}{ Body } & \multirow[b]{2}{*}{ 总 } & \multirow[b]{2}{*}{ 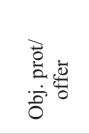 } & \multirow[b]{2}{*}{ 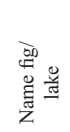 } & \multirow[b]{2}{*}{$\begin{array}{l}\frac{7}{0} \\
\dot{0} \\
\dot{0}\end{array}$} \\
\hline & $\stackrel{\dot{b}}{\dot{D}}$ & 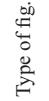 & 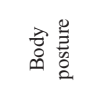 & $\frac{\overline{0}}{0}$ & 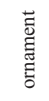 & $\frac{\overline{0}}{8}$ & $\overbrace{\vec{z}}^{\infty}$ & & & & \\
\hline \multirow{2}{*}{$\begin{array}{l}\text { pParis Louvre N. } \\
3149,3204 \mathrm{~B}, 3123 \\
\text { bis }+3213 \\
\text { [Armant, Thebes] }\end{array}$} & $\mathrm{A} \leftarrow$ & 1 & 2 & $\mathrm{Ou}$ & No & $\mathrm{Ou}$ & No & $\approx$ & mo & \multirow{2}{*}{ No } & $\varnothing$ \\
\hline & $\mathrm{B} \leftarrow$ & 1 & 3 & $\mathrm{Ou}$ & No & $\mathrm{Ou}$ & No & $\cong$ & $\square$ & & p \\
\hline \multirow{2}{*}{$\begin{array}{l}\text { pParis Louvre N. } 3248 \\
\text { [Thebes] }\end{array}$} & $\mathrm{A} \leftarrow$ & $1 ?$ & 2 or $3 ?$ & $\mathrm{Ou}$ & - & $\mathrm{Ou}$ & No & $\cong$ & $\square$ & \multirow{2}{*}{ No } & - \\
\hline & $\mathrm{B} \leftarrow$ & $1 ?$ & 2 or $3 ?$ & $\mathrm{~K}$ & No & $\mathrm{Ou}$ & No & - & - & & - \\
\hline \multirow{2}{*}{$\begin{array}{l}\text { pTurin } 1831 \\
\text { [Thebes] }\end{array}$} & $\mathrm{A} \leftarrow$ & 1 & 2 & $\mathrm{~K}$ & No & $\mathrm{D}>\mathrm{B}$ & No & $\approx$ & $\varnothing$ & \multirow{2}{*}{ No } & $\varnothing$ \\
\hline & $\mathrm{B} \leftarrow$ & 1 & 2 & $\mathrm{~K}$ & No & $\mathrm{L}>\mathrm{A}$ & No & $\cong$ & $\mathrm{O}$ & & $\varnothing$ \\
\hline \multirow{2}{*}{$\begin{array}{l}\text { pTurin } 1833 \\
\text { [Thebes] }\end{array}$} & $\mathrm{A} \leftarrow$ & 1 & 2 & $\mathrm{~K}$ & No & $\mathrm{L}$ & No & $\cong$ & pary & \multirow{2}{*}{ No } & $\varnothing$ \\
\hline & $\mathrm{B} \leftarrow$ & 1 & 2 & $\mathrm{~K}$ & No & $\mathrm{L}$ & No & $\cong$ & $\square$ & & $\varnothing$ \\
\hline \multirow{2}{*}{$\begin{array}{l}\text { pUnknown location, } \\
T 3-b r \\
\text { [Thebes] }\end{array}$} & $\mathrm{X} \leftarrow^{37}$ & $?$ & $?$ & $?$ & $?$ & $?$ & No & $?$ & $\square^{36}$ & \multirow[b]{2}{*}{ No } & - \\
\hline & - & - & - & - & - & - & - & - & - & & - \\
\hline
\end{tabular}

36. Only part of an object of elongated shape laying over the groundline is preserved.

37. The identification of the image of the lakes in this papyrus, of which only one figure seems to be preserved, is not certain. 
Table VII: Ptolemaic Papyri, Memphis

\begin{tabular}{|c|c|c|c|c|c|c|c|c|c|c|c|}
\hline \multirow{2}{*}{$\mathrm{N}^{\circ}$ of Inv./ provenance } & \multicolumn{5}{|c|}{ Wig } & \multicolumn{2}{|c|}{ Body } & \multirow[b]{2}{*}{ 竞 } & \multirow[b]{2}{*}{ 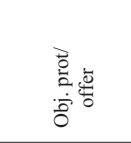 } & \multirow[b]{2}{*}{ 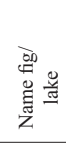 } & \multirow[b]{2}{*}{$\begin{array}{l}\frac{7}{2} \\
\frac{0}{0} \\
0\end{array}$} \\
\hline & 殶 & 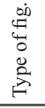 & 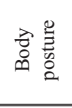 & $\frac{\overline{0}}{8}$ & 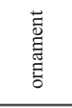 & $\frac{\overline{0}}{8}$ & 童 & & & & \\
\hline \multirow{2}{*}{$\begin{array}{l}\text { pCairo CG. } 40029 \\
\text { Memphis }^{38}\end{array}$} & - & - & - & - & - & - & - & - & - & \multirow{2}{*}{ No } & - \\
\hline & $\mathrm{B} \leftarrow$ & 1 & 3 & $\mathrm{Ou}$ & No & $\mathrm{Ou}$ & No & & (5) & & $x$ \\
\hline \multirow{2}{*}{$\begin{array}{l}\text { pParis Louvre N. } 5450 \\
{[\text { Memphis }]^{38}}\end{array}$} &,$- \varnothing ?$ & - & - & - & - & - & - & - & - & \multirow{2}{*}{ No } & - \\
\hline & $\mathrm{B} \leftarrow$ & 1 & 3 & $\mathrm{Ou}$ & No & $\mathrm{Ou}$ & No & & p & & \\
\hline \multirow{2}{*}{$\begin{array}{l}\text { pVienna Vindob. } \\
\text { Aeg. } 65 \\
{[\text { Memphis }]^{39}}\end{array}$} & $\mathrm{~A} \leftarrow$ & 4 & 3 & $\mathrm{Ou}$ & Lace & $\mathrm{Ou}$ & No & $\approx$ & $\Longrightarrow$ & \multirow{2}{*}{ No } & \\
\hline & $\mathrm{B} \leftarrow$ & 4 & 3 & $\mathrm{Ou}$ & Lace & $\mathrm{Ou}$ & No & $\cong$ & $\Longrightarrow$ & & \\
\hline \multirow{2}{*}{$\begin{array}{l}\text { pParis Louvre N. } 3081 \\
{[\text { Memphis }]^{39}}\end{array}$} & $\mathrm{~A} \leftarrow$ & 4 & 3 & $\mathrm{Ou}$ & Lace & $\mathrm{Ou}$ & No & $\approx$ & 2 & \multirow{2}{*}{ No } & \\
\hline & $\mathrm{B} \leftarrow$ & 4 & 3 & $\mathrm{Ou}$ & Lace & $\mathrm{Ou}$ & No & $\approx$ & 2 & & \\
\hline \multirow{2}{*}{$\begin{array}{l}\text { pLeiden T17 } \\
\text { Memphis }\end{array}$} & $\mathrm{A} \leftarrow$ & 1 & 3 & $\mathrm{Ou}$ & No & $\mathrm{Ou}$ & No & & $\square$ & \multirow{2}{*}{ No } & \\
\hline & $\mathrm{B} \leftarrow$ & 1 & 3 & $\mathrm{Ou}$ & No & $\mathrm{Ou}$ & No & $\approx$ & $\square$ & & 度 \\
\hline \multirow{2}{*}{$\begin{array}{l}\text { pBerlin P. } 3149 \\
\text { [Memphis] }\end{array}$} & $\mathrm{A} \leftarrow$ & 1 & 3 & $\mathrm{Ou}$ & 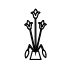 & $\mathrm{Ou}$ & No & & & \multirow{2}{*}{ No } & 展 \\
\hline & $\mathrm{B} \leftarrow$ & 1 & 3 & $\mathrm{Ou}$ & - & $\mathrm{Ou}$ & No & $\approx$ & & & \\
\hline \multirow{2}{*}{$\begin{array}{l}\text { pCairo J.E. } 32887 \\
\text { [Memphis] }\end{array}$} & $\mathrm{A} \leftarrow$ & $?$ & 3 & - & - & - & - & & b & \multirow{2}{*}{ No } & \\
\hline &,$- \varnothing ?$ & - & - & - & - & - & - & - & - & & - \\
\hline \multirow{2}{*}{$\begin{array}{l}\text { pVienna ÄS } 3862 \\
(3856-58,3864 \\
3866-69)+10159 \\
\text { Memphis }^{38}\end{array}$} & $\mathrm{~A} \leftarrow$ & 1 & 2 & $\mathrm{Ou}$ & No & $\mathrm{Ou}$ & No & $\approx$ & $\square$ & \multirow{2}{*}{ No } & $\varnothing$ \\
\hline & $\mathrm{B} \leftarrow$ & 1 & 3 & $\mathrm{Ou}$ & No & $\mathrm{Ou}$ & No & $\cong$ & (5) & & \\
\hline \multirow{2}{*}{$\begin{array}{l}\text { pVienna Vindob. } \\
\text { Aeg. } 10.110 \\
\text { Memphis }\end{array}$} & $\mathrm{A} \leftarrow$ & 1 & 2 & $\mathrm{Ou}$ & No & $\mathrm{Ou}$ & No & $\cong$ & $\square$ & \multirow[b]{2}{*}{ No } & $\varnothing$ \\
\hline & $\mathrm{B} \leftarrow$ & 1 & 3 & $\mathrm{Ou}$ & No & $\mathrm{Ou}$ & No & 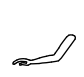 & ${ }^{41}$ & & 度 \\
\hline
\end{tabular}

38. Possibly stemming from the same workshop, but the owners are not related by name or titulature.

39. Executed in the same workshop, but the owners are not related by titulature.

40. From the upper part of the stem hangs an object similar to a heb-sed pavilion.

41. The damage suffered in this part of the document makes it impossible to know whether the space was left blank or an eye inside an oval was depicted. 


\begin{tabular}{|c|c|c|c|c|c|c|c|c|c|c|c|}
\hline \multirow[b]{2}{*}{$\mathrm{N}^{\circ}$ of Inv./ provenance } & \multicolumn{5}{|c|}{ Wig } & \multicolumn{2}{|c|}{ Body } & \multirow[b]{2}{*}{ 哭 } & \multirow[b]{2}{*}{ 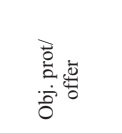 } & \multirow[b]{2}{*}{ 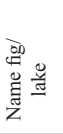 } & \multirow[b]{2}{*}{ 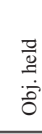 } \\
\hline & 流 & 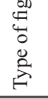 & 存善 & $\frac{\overline{0}}{\frac{0}{8}}$ & 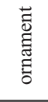 & $\frac{\overline{0}}{0}$ & 站 & & & & \\
\hline \multirow{2}{*}{$\begin{array}{l}\text { pBerlin P. } 10477 \\
\text { Akhmin } \\
\text { Subtradition B }\end{array}$} & $A \rightarrow{ }^{46}$ & 4 & 3 & $\mathrm{Ou}$ & No & $\mathrm{Ou}$ & No & $\approx$ & $\Longrightarrow$ & \multirow{2}{*}{ No } & \\
\hline & $\mathrm{B} \rightarrow$ & 4 & 2 & $\mathrm{Ou}$ & No & $\mathrm{Ou}$ & No & $\approx$ & 而 & & $\varnothing$ \\
\hline \multirow{2}{*}{$\begin{array}{l}\text { pMacGregor } \\
\text { Akhmin } \\
\text { Subtradition B }\end{array}$} & $\mathrm{A} \rightarrow$ & 4 & 3 & $\mathrm{~K}$ & No & $\mathrm{Ou}$ & No & $\approx$ & 而 & \multirow[b]{2}{*}{ No } & $\varnothing$ \\
\hline & $\mathrm{B} \rightarrow$ & 4 & 2 & $\mathrm{~K}$ & No & $\mathrm{Ou}$ & No & $\approx$ & $\infty$ & & s? \\
\hline \multirow{2}{*}{$\begin{array}{l}\text { pNew Brunswick } \\
\text { Akhmin } \\
\text { Subtradition A }\end{array}$} & $\mathrm{A} \leftarrow$ & 1 & 3 & $\mathrm{Ou}$ & No & $\mathrm{Ou}$ & No & $\approx$ & $\varnothing$ & \multirow{2}{*}{ No } & \\
\hline & $\mathrm{B} \leftarrow$ & 1 & 2 & $\mathrm{Ou}$ & No & $\mathrm{Ou}$ & No & & 禺 & & $\varnothing$ \\
\hline \multirow{2}{*}{$\begin{array}{l}\text { pLondon BM } 10479 \\
\text { Akhmin } \\
\text { Subtradition A }\end{array}$} & $\mathrm{A} \rightarrow$ & 4 & 2 & $\mathrm{Ou}$ & No & $\mathrm{Ou}$ & $\mathrm{No}^{45}$ & $\approx$ & $\square$ & \multirow[b]{2}{*}{ No } & $\varnothing$ \\
\hline & $\mathrm{B} \rightarrow$ & 4 & 3 & $\mathrm{Ou}$ & No & $\mathrm{Ou}$ & No & $\approx$ & $\alpha$ & & $\sqrt{3}$ \\
\hline \multirow{2}{*}{$\begin{array}{l}\text { pParis Louvre } \\
\text { E. } 11078 \\
\text { Akhmin }{ }^{47}\end{array}$} & $\mathrm{~A} \rightarrow$ & 1 & 2 & $\mathrm{Ou}$ & No & $\mathrm{Ou}$ & No & $\approx$ & $\bar{\nabla}^{44}$ & \multirow{2}{*}{ No } & \\
\hline & $\mathrm{B} \rightarrow$ & 1 & 3 & $\mathrm{Ou}$ & No & $\mathrm{Ou}$ & No & $\approx$ & 0 & & \\
\hline
\end{tabular}

42. Mosher describes the vignettes from this tradition (2001: 18, 23) and suggests a Memphite origin for the images relating to chapter BD 17.

43. The stem is shorter than in the rest of sources from Akhmin, in which it usually leans against the ground and is placed across the body of the figure passing either in front or behind it.

44. The presence of the altar or table with high foot is exceptional and possibly foreign to these vignettes.

45. In this papyrus the breasts of the two women protrude over the dress and are emphasized by means of horizontal lines. Conversely, in the rest of documents from Akhmin, the breasts are hidden under tight and long dresses (as in pBerlin P. 10477 and pMacGregor).

46. As an exception, both figures occupy registers superimposed and separated by a horizontal line. We shall consider figure $\mathrm{A}$ as the one depicted in the upper register, and $\mathrm{B}$ in the lower one.

47. Mosher rejects that this papyrus belongs to the group of Akhmin, due to the textual and formal differences with the other sources (2001: 36). 
Table IX: Ptolemaic Papyrus, Middle Egypt

\begin{tabular}{|c|c|c|c|c|c|c|c|c|c|c|c|}
\hline \multirow[b]{2}{*}{$\mathrm{N}^{\circ}$ of Inv./ provenance } & \multicolumn{5}{|c|}{ Wig } & \multicolumn{2}{|c|}{ Body } & \multirow[b]{2}{*}{ 曾 } & \multirow[b]{2}{*}{ 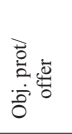 } & \multirow[b]{2}{*}{$\begin{array}{l}\text { DD } \\
\text { है } \\
\text { है } \\
\text { है }\end{array}$} & \multirow[b]{2}{*}{ 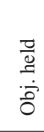 } \\
\hline & 竞 & 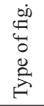 & 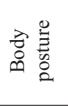 & $\frac{\overline{0}}{8}$ & 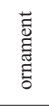 & $\frac{\overline{0}}{8}$ & $\sum_{\substack{n \\
3}}^{\infty}$ & & & & \\
\hline \multirow{2}{*}{$\begin{array}{l}\text { pChicago OIM } 10486 \\
\text { Meir }\end{array}$} & $\mathrm{A} \leftarrow$ & 3 & 2 & $\mathrm{Ou}$ & No & $\mathrm{Ou}$ & No & & $\mathrm{X}^{49}$ & \multirow{2}{*}{ No } & - \\
\hline & $\mathrm{B} \leftarrow$ & 3 & 2 & $\mathrm{Ou}$ & No & $\mathrm{Ou}$ & No & & $\infty$ & & \\
\hline
\end{tabular}

48. Anomalous object composed of a mooring post, with its upper ending curved outwards and an element similar to a knife protruding sideways. Mosher describes it as the šmsw-sign (\$) $)-1990: 650$, n. 6.

49. Mosher suggests that a confusion took place between the two rectangles (which are a hallmark of the rest of documents) and the two chapels depicted (probably a reference to both the door of Naref and the resting place of Osiris mentioned in the glosses of BD 17 § S9) -1990: 650, n. 7. 
Table X: Ptolemaic Papyri, Unknown Provenance

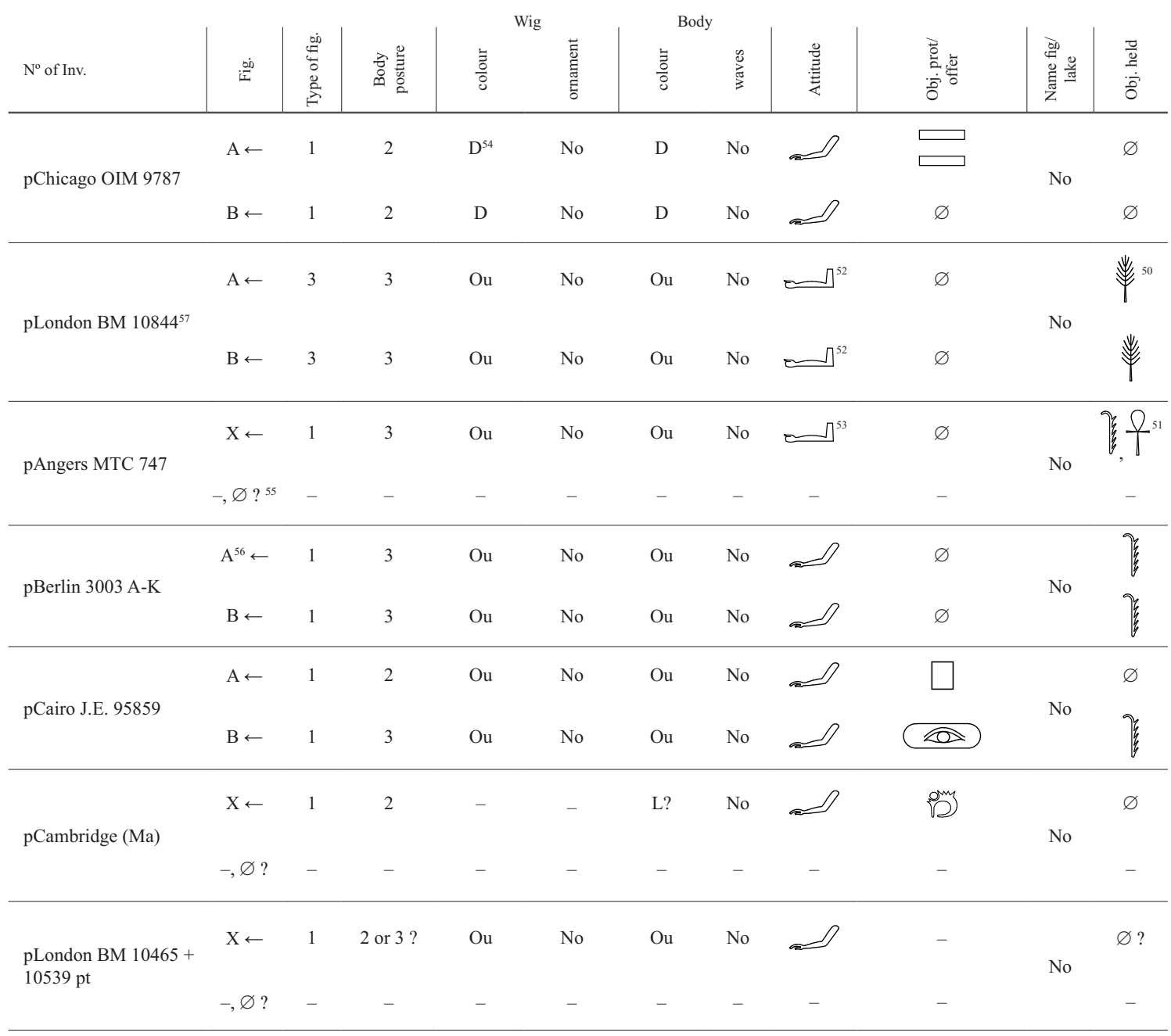

50. Only one other document from Thebes (pAberdeen ABDUA 84023, 1-7) shows a figure holding a branch with the hand in the background.

51. Only one more instance is known of a figure holding a branch and an ankh-sign in the same hand -pDublin 1661 from the 19th Dynasty - but in this case, the objects are held in different hands.

52. The attitude of the characters with clenched fists differs from the rest of sources which display protective and offering gestures.

53. In contrast with the rest of documents, the hand in the background does not perform the act of protecting or offering, but grasps an object.

54. Colours are difficult to ascertain; Allen points out that the papyrus is a rare example in the Ptolemaic Period for its use of light and dark blue, green, brown and yellow tones, but does not mention which is the colour of the figures of the lakes (1960: 19).

55. The document is neatly cut and probably was divided in segments for its sale in the antiquities market. We cannot determine if a second figure was included, for the location of the rest of the papyrus is unknown.

56. The two figures are depicted so close to each other that from the rear one, only the profile is visible. We shall consider that figure $\mathrm{A}$ is the one situated in the front and $\mathrm{B}$ the one placed behind.

57. Quirke suggests that this document might have been written as a copy for a temple library instead of as a papyrus for burial. Many vignettes were not completed and show the guide lines (1999 a: 91). 


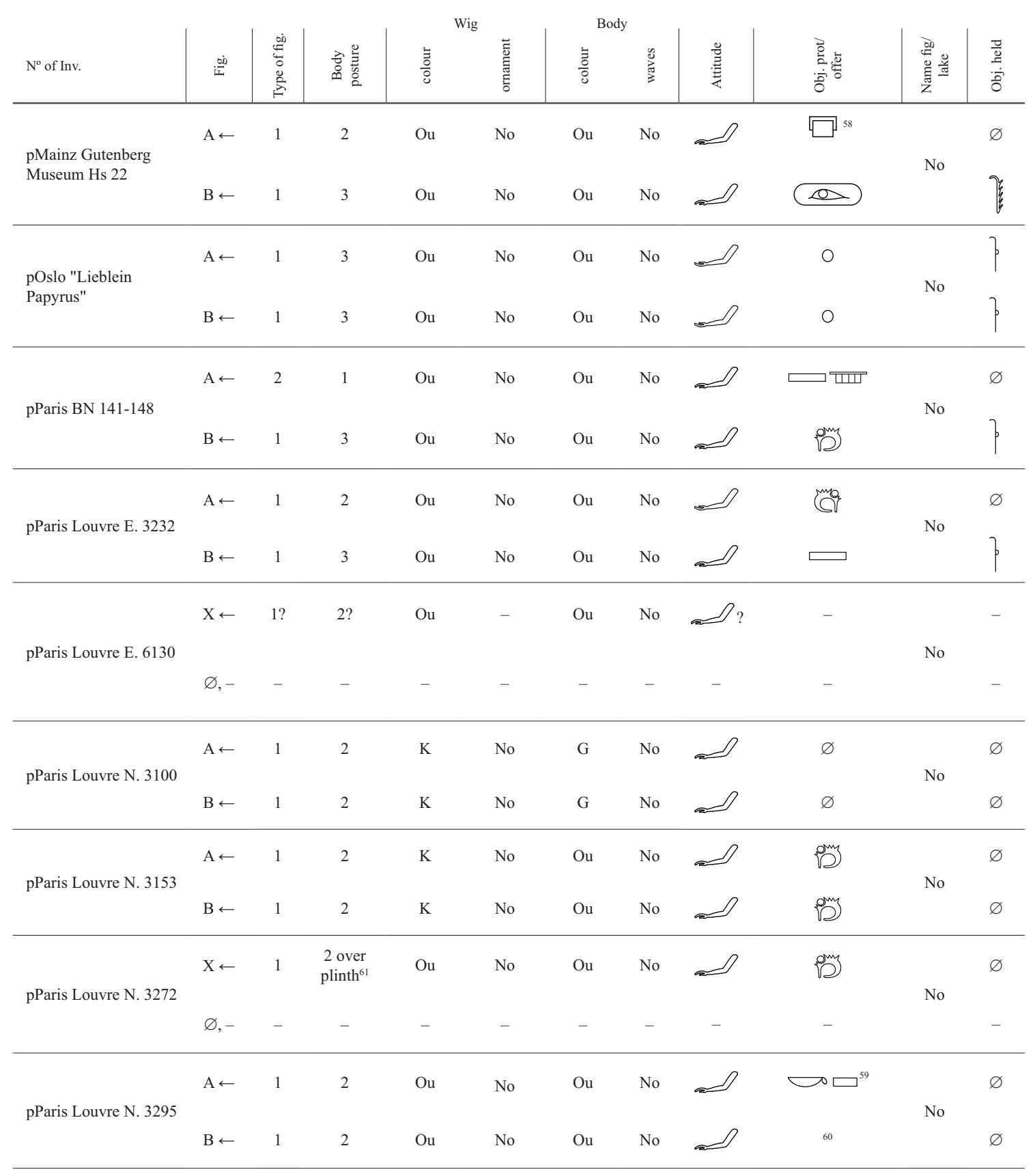

58 The element protected is partially hidden behind the legs of the first figure and its rim projects out of the base.

59. The first object has no recognizable shape, though the protuberance on one side gives it the appearance of a bowl or a container.

60. The object/s protected by the figure are too damaged to recognize, but it/they could be an /two eye/s.

61. The figure seems to be placed over a small podium or plinth, but since the central part of the scene is lost, the possibility that he rested on a reed mat, as in some sources of the New Kingdom, cannot be ruled out. 


\begin{tabular}{|c|c|c|c|c|c|c|c|c|c|c|c|}
\hline \multirow[b]{2}{*}{$\mathrm{N}^{\circ}$ of Inv. } & \multicolumn{5}{|c|}{ Wig } & \multicolumn{2}{|c|}{ Body } & \multirow[b]{2}{*}{ 总 } & \multirow[b]{2}{*}{ 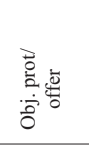 } & \multirow[b]{2}{*}{ 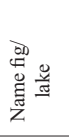 } & \multirow[b]{2}{*}{$\begin{array}{l}\frac{\pi}{0} \\
\stackrel{0}{\circ} \\
0\end{array}$} \\
\hline & id & 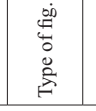 & 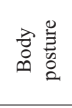 & $\frac{\overline{0}}{0}$ & 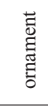 & $\frac{\bar{y}}{\frac{0}{8}}$ & 离 & & & & \\
\hline \multirow{2}{*}{$\begin{array}{l}\text { pSydney R } 87 \text { a, b, } \\
\text { c, d, e }\end{array}$} & $X \leftarrow$ & 1 & 3 & $\mathrm{Ou}$ & No & $\mathrm{Ou}$ & No & $\approx$ ? & bin - & \multirow{2}{*}{ No } & 㞔 \\
\hline & $\varnothing,-$ & - & - & - & - & - & - & - & - & & - \\
\hline \multirow{3}{*}{ pTurin 1834} & $\mathrm{~A} \leftarrow$ & 1 or 4 ? & 2 & $\mathrm{Ou}$ & No & $\mathrm{Ou}$ & No & . & 初 & \multirow{3}{*}{ No } & $\varnothing$ \\
\hline & & & & & & & & & & & \\
\hline & $\mathrm{B} \leftarrow$ & 1 & 2 & $\mathrm{Ou}$ & No & $\mathrm{Ou}$ & No & $\cong$ & (2) & & $\varnothing$ \\
\hline \multirow{2}{*}{ pTurin 1835} & $\mathrm{~A} \leftarrow$ & 1 & 2 & $\mathrm{Ou}$ & No & $\mathrm{Ou}$ & No & $\Omega$ & $\square$ & \multirow{2}{*}{ No } & $\varnothing$ \\
\hline & $\mathrm{B} \leftarrow$ & 1 & 2 & $\mathrm{Ou}$ & No & $\mathrm{Ou}$ & No & $\cong$ & 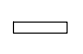 & & $\varnothing$ \\
\hline \multirow{3}{*}{ pZagreb 600} & $\mathrm{~A} \leftarrow$ & 1 & 2 & K & No & $\mathrm{Ou}$ & No & $\cong$ & O & \multirow{3}{*}{ No } & $\varnothing$ \\
\hline & & & & & & & & & & & \\
\hline & $\mathrm{B} \leftarrow$ & $1 ?$ & 2 & K & - & $\mathrm{Ou}$ & No & $\cong$ & O & & $\varnothing$ \\
\hline
\end{tabular}


Table Xi: Mummy Bandages (Ptolemaic Period)

\begin{tabular}{|c|c|c|c|c|c|c|c|c|c|c|c|}
\hline \multirow[b]{2}{*}{$\mathrm{N}^{\circ}$ of Inv./ provenance } & \multicolumn{5}{|c|}{ Wig } & \multicolumn{2}{|c|}{ Body } & \multirow[b]{2}{*}{ 总 } & \multirow[b]{2}{*}{ 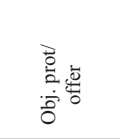 } & \multirow[b]{2}{*}{ 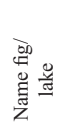 } & \multirow[b]{2}{*}{$\begin{array}{l}\frac{0}{0} \\
\stackrel{0}{0}\end{array}$} \\
\hline & 梷 & 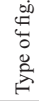 & 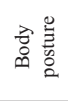 & $\frac{\bar{z}}{8}$ & 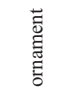 & $\frac{\overline{0}}{0}$ & $\overbrace{\substack{3 \\
3}}^{\infty}$ & & & & \\
\hline \multirow{2}{*}{$\begin{array}{l}\text { M. Aberdeen ABDUA } \\
23552+56040+ \\
56041+84070+ \\
84071+84072 \ldots \\
\text { [Gurob] }\end{array}$} & $\mathrm{A} \leftarrow$ & 1 & 3 & $\mathrm{Ou}$ & - & $\mathrm{Ou}$ & No & & $\varnothing$ & \multirow[b]{2}{*}{ No } & \\
\hline & $\mathrm{B} \leftarrow$ & - & 3 & $\mathrm{Ou}$ & - & $\mathrm{Ou}$ & No & $\approx$ & $\Longrightarrow(!)^{63}$ & & \\
\hline \multirow{2}{*}{$\begin{array}{l}\text { M. Aberdeen ABDUA } \\
23542+23546+ \\
23554+56026+\ldots \\
\text { [Saqqara?] }\end{array}$} & $\mathrm{A} \leftarrow$ & 1 & 3 & $\mathrm{Ou}$ & $\sqrt[9]{9}$ & $\mathrm{Ou}$ & No & & $\varnothing$ & \multirow{2}{*}{ No } & \\
\hline & $\mathrm{B} \leftarrow$ & 1 & 3 & $\mathrm{Ou}$ & $\sqrt[8]{9}$ & $\mathrm{Ou}$ & No & $\approx$ & $\varnothing$ & & \\
\hline \multirow{2}{*}{$\begin{array}{l}\text { M. Aberdeen ABDUA } \\
84041.1 \\
\text { Unknown provenance }\end{array}$} & $\mathrm{A} \leftarrow$ & 1 & $2^{65}$ & $\mathrm{Ou}$ & No & $\mathrm{Ou}$ & No & - & - & \multirow{2}{*}{ No } & $\varnothing^{65}$ \\
\hline & $\mathrm{B} \leftarrow$ & 1 & 3 & $\mathrm{Ou}$ & No & $\mathrm{Ou}$ & No & $\approx$ & (i) & & $\xi$ \\
\hline \multirow{2}{*}{$\begin{array}{l}\text { M. Aberdeen ABDUA } \\
23213+23214 \\
\text { Unknown provenance }\end{array}$} & $X \leftarrow$ & 1 & 3 & $\mathrm{Ou}$ & Lace & $\mathrm{Ou}$ & No & & 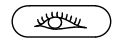 & \multirow{2}{*}{ No } & \\
\hline & $\varnothing,-?$ & - & - & - & - & - & - & - & - & & - \\
\hline \multirow{2}{*}{$\begin{array}{l}\text { M. Aberdeen ABDUA } \\
84216+84274 \\
\text { Unknown provenance }\end{array}$} & $X \leftarrow$ & 1 & 3 & $\mathrm{Ou}$ & $\sqrt[0]{0}$ & $\mathrm{Ou}$ & No & & ह1 & \multirow{2}{*}{ No } & 证 \\
\hline & $\varnothing,-?$ & - & - & - & - & - & - & - & - & & - \\
\hline \multirow{2}{*}{$\begin{array}{l}\text { M. Boston MFA } \\
59.1070 \\
\text { Gurob }\end{array}$} & $\mathrm{A} \leftarrow$ & 1 & 3 & $\mathrm{Ou}$ & No & $\mathrm{Ou}$ & No & $\approx$ & $\varnothing$ & \multirow{2}{*}{ No } & V \\
\hline & $\mathrm{B} \leftarrow$ & 1 & 3 & $\mathrm{Ou}$ & No & $\mathrm{Ou}$ & No & $\approx$ & $\varnothing$ & & 莎 \\
\hline \multirow{2}{*}{$\begin{array}{l}\text { M. Los Angeles } 83 . \\
\text { AI. } 47.1 .4 \\
\text { Unknown provenance }\end{array}$} & $\mathrm{A} \leftarrow$ & 1 & 3 & $\mathrm{Ou}$ & No & $\mathrm{Ou}$ & No & $\approx$ & ¿ & \multirow{2}{*}{ No } & 唼 \\
\hline & $\mathrm{B} \leftarrow$ & 1 & 3 & $\mathrm{Ou}$ & No & $\mathrm{Ou}$ & No & $\approx$ & $\rightleftarrows^{64}$ & & 唼 \\
\hline \multirow{2}{*}{$\begin{array}{l}\text { M. Los Angeles } 83 \text {. } \\
\text { AI. } 47.2 .3 \\
\text { Unknown provenance }\end{array}$} & $\mathrm{A} \leftarrow$ & 1 & 3 & $\mathrm{Ou}$ & No & $\mathrm{Ou}$ & No & $\approx$ & 0 & \multirow{2}{*}{ No } & $\xi$ \\
\hline & $\mathrm{B} \leftarrow$ & 1 & 3 & $\mathrm{Ou}$ & No & $\mathrm{Ou}$ & No & $\approx$ & 0 & & 该 \\
\hline \multirow{2}{*}{$\begin{array}{l}\text { M. Paris Louvre N } \\
3138+3058 \\
{[\text { Memphis }]}\end{array}$} & $\mathrm{A} \leftarrow$ & 1 & 2 & $\mathrm{Ou}$ & No & $\mathrm{Ou}$ & No & $\approx$ & $\square$ & \multirow{2}{*}{ No } & - \\
\hline & $\mathrm{B} \leftarrow$ & 1 & 3 & $\mathrm{Ou}$ & No & $\mathrm{Ou}$ & No & $\approx$ & (m) & & \\
\hline
\end{tabular}

62. In contrast to the other sources, the branches held are depicted obliquely. The position of the arm of the figres is anomalous; the elbow is bent in a very acute angle, the forearm projects upwards and the hand holding the object lays halfway between the elbow and the shoulder.

63. The element inside the oval is rendered with two horizontal strokes, the upper one being larger than the lower one, and so simplified that no clear object would be recognizable without the aid of other sources.

64. The oval around the stroke (a simplified eye?) rests over a structure similar to a small podium or altar.

65. Even though the hands of the figure are not preserved, the absence of the ending of a branch near the legs may indicate that no object was being held. 


\begin{tabular}{|c|c|c|c|c|c|c|c|c|c|c|c|}
\hline \multirow[b]{2}{*}{$\mathrm{N}^{\circ}$ of Inv./ provenance } & \multicolumn{5}{|c|}{ Wig } & \multicolumn{2}{|c|}{ Body } & \multirow[b]{2}{*}{ 宔 } & \multirow[b]{2}{*}{ 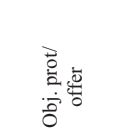 } & \multirow[b]{2}{*}{ 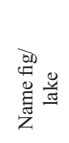 } & \multirow[b]{2}{*}{ 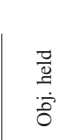 } \\
\hline & id & 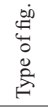 & 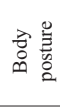 & $\frac{\bar{z}}{8}$ & 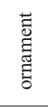 & $\frac{\bar{z}}{0}$ & $\overbrace{\mathbb{3}}^{\mathscr{S}}$ & & & & \\
\hline \multirow{2}{*}{$\begin{array}{l}\text { M. Viena ÄS } 3848 \\
\text { Unknown provenance }\end{array}$} & $\mathrm{A} \leftarrow$ & 1 & 3 & $\mathrm{Ou}$ & No & $\mathrm{Ou}$ & No & $\approx$ & O & \multirow{2}{*}{ No } & 展 \\
\hline & $\mathrm{B} \leftarrow$ & 1 & 3 & $\mathrm{Ou}$ & No & $\mathrm{Ou}$ & No & $\approx$ & O & & 虔 \\
\hline \multirow{2}{*}{$\begin{array}{l}\text { M. Hildesheim LH } 8 \\
\text { Not recorded }\end{array}$} & $\mathrm{A} \leftarrow$ & 1 & 2 & $\mathrm{Ou}$ & No & $\mathrm{Ou}$ & No & & $m^{m}$ & \multirow{2}{*}{ No } & $\varnothing$ \\
\hline & $\mathrm{B} \leftarrow$ & 1 & 3 & $\mathrm{Ou}$ & No & $\mathrm{Ou}$ & No & $\cong$ & O & & \\
\hline \multirow{2}{*}{$\begin{array}{l}\text { M. Simonian Private } \\
\text { Collection } 1(\mathrm{~g}, 1-2) \\
\text { [Heracleopolis Magna] }\end{array}$} & $\mathrm{A} \leftarrow$ & 1 & 3 & $\mathrm{Ou}$ & No & $\mathrm{Ou}$ & No & $\cong$ & $\rightleftharpoons^{66}$ & \multirow{2}{*}{ No } & \\
\hline & $\mathrm{B} \leftarrow$ & 1 & 3 & $\mathrm{Ou}$ & No & $\mathrm{Ou}$ & No & $\cong$ & 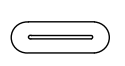 & & \\
\hline
\end{tabular}

66. There could be an object with no clear shape (a lake?) above the figure's hand, but the fact that the bandage has grown darker on the spot prevents its recognition. 


\section{BIBLIOGRAPHY}

Affholder-GÉrard, B.; Cornic, M.Y.

1990 Angers, Musée Pincé, Collections Égyptiennes, Paris.

Allen, J.P.

1988 Genesis in Egypt. The Philosophy of Ancient Egyptian Creation Accounts, (YES 2), New Haven.

1992-1993 "A Late Book of the Dead in the Oriental Institute Collection", AJSL 49: 141-149.

AlLen, T.G.H.

1960 The Egyptian Book of the Dead. Documents in the Oriental Institute Museum at the University of Chicago, (OIP 82), Chicago.

1974 The Book of the Dead or Going Forth by Day: Ideas of the Ancient Egyptian Concerning the Hereafter as Expressed in their own Terms, (SAOC 37), Chicago.

AltenMüller, B.

1977a s.u. "Harsaphes", L $\ddot{A}$ II, 1015-1018.

1977 b s.u. "Heh", $L \ddot{A}$ II, 1082-1084.

Assmann, J.

1989 "Death and Initiation in the Funerary Religion of Ancient Egypt", in Simpson, W.K. (ed.): Religion and Philosophy in Ancient Egypt, (YES 3), New Haven: 135-159.

2002, 2005 Altägyptische Totenliturgien, Band 1. Totenliturgien in den Sargtexten des en und Totensprüche in Grabinschriften des Neuen Reiches, (Supplemente zu den Inschriften der Heidelberger Akademie der Wissenschaften Philosophischen historische Klasse 14 y 17), Heidelberg.

Aufrère, S.H., ET AL.

1992 Portes pour l'au-delà : l'Égypte, le Nil et le «champ des offrandes»: catalogue

de l'exposition, Musée Archéologique Henri Prados, Paris.

BAINES, J.

1985 Fecundity Figures, Egyptian Personification and the Iconology of a Genre, Warminster.

BARGUet, P.

1986 Textes des Sarcophagues du Moyen Empire, (LAPO 12), Paris.

2000 [1967] El Libro de los Muertos de los antiguos egipcios, Bilbao.

BAUD, M.

1995 "La date d'apparition des hntyw-š", BIFAO 96: 13-49.

BeInlich, $\mathrm{H}$.

1991 Das Buch von Fayum. Zum Eigenverständnis einer ägyptischen Landschaft, ( $\ddot{A A}$ 51), Wiesbaden.

BELLION, M.

1987 Catalogue des Manuscrits hiéroglyphiques et hiératiques et des Dessins, sur Papyrus, Cuir ou Tissu, Publiés ou Signalés (Égypte Ancienne), Paris.

Bienkowski, P.; ToOLey, A.

1995 Gifts of the Nile: Ancient Egyptian Arts and Crafts in Liverpool Museum, London.

Bietak, H.; Reiser-Haslauer, E.

1978, 1982 Das Grab des 'Anch-Hor, II Band., (Untersuchungen der Zweigstelle Kairo der Österreischischen Archäologischen Institutes III y IV), Wien.

BLACKMAN, A.W.

1921 "Sacramental ideas and usages in Ancient Egypt", RT 39: 44-78.

BONNET, $\mathrm{H}$.

2000 [1952] Reallexikon der Ägyptischen 
Religionsgeschichte, Hamburg.

BORCHARDT, L.

1925 Statuen und Statuetten von Königen und Privatleuten, Catalogue Général des Antiquités Égyptiennes du Musée du Caire, Teil II (Nr. 381-653), Berlin.

Bosticco, S.

1975 "Due frammenti di un papiro funerario nel Museo egizio di Firenze", Aegyptus 37: 71-76, fig. 1-2.

Bотті, G.

1964 I Cimeli egizi del Museo di Antichità di Parma, Florencia.

BREASTED, H.

1906-1907 Ancient Records of Egypt, Historical Documents from the Earliest Times to the Persian Conquest, 5 vols., Chicago.

BRUGSCH, $\mathrm{H}$.

1974 [1879] Dictionnaire géographique de l'ancienne Égypte, Hildesheim, New York.

Brunton, G.

1927 Qau and Badari I, (BSAE 27), London.

BuRKARD, G.; Fischer-ElFert, H.W.

1994 Ägyptische Handschriften Teil 4, (Verzeichnis der Orientalischen Handschriften in Deutschland XIX. 4), Stuttgart.

BUHL, M-L.

1974 A hundred masterpieces from the Ancient Near East in the National Museum of Denmark and the History of its Ancient Near Eastern Collections, Copenhaguen.

BUROH, K. ET AL.

1985 Hieroglyphenschrift und Totenbuch. Die Papyri der Ägyptischen Sammlung der Universität Tübingen, Tübingen.
Chappaz, J.L.; Poggia, S.

1996 Collections égyptiennes publiques de Suisse, (CSÉG 3), Genève.

Charron, A. (DIr.)

2002 La mort n'est pas un fin. Pratiques funéraires en Égypte d'Alexandre à Cléopâtre, Catalogue de l'exposition 28 septembre $2002-5$ janvier 2003, Musée de l'Arlés Antique.

CLÈre, J.

1987 Le Papyrus de Nesmin, un Livre des Morts Hiéroglyphique de l'Époque Ptolémä̈que, Le Caire.

CoEnen, $\mathrm{M}$

1999 "The Graeco-roman Mortuary Papyri in the National Museum of Antiquities at Leiden", OMRO 79: 67-79.

2006 "A Preliminary Survey of the Books of the Dead on Papyrus and Linen in the Nicholson Museum", in Sowada, K.; Ockinga, B. (eds.): Egyptian Art in the Nicholson Museum, Sydney, Sydney: 81-89.

Curtis, N.G.W.; Kockelmann, H.; Munro, I.

2005 "The Collection of the Book of the Dead Manuscripts in Marischal Museum, University of Aberdeen, Scotland. A Comprehensive Overview", BIFAO 105: 49-73.

DARESSY, G.

1919 "Statue de Zedher le Sauveur", ASAE 18: 113-158.

D'Auria, S. ET AL.

1988 Mummies and Magic -the Funerary Arts of Ancient Egypt, Boston.

De Buck, A.

1935-1961 The Egyptian Coffin Texts, 7 vols., Chicago. 
De Caluwe, A.

1991 Un livre des Morts sus bandelettes de momie, (Bibliotheca Aegyptiaca 18), Brüssels.

De Rougé, E.

1861-1876 Études sur le Rituel Funéraire des Anciens Égyptiens, Paris.

De Wit, C.

1979 "Les Valeurs du signe de l'oeil dans le système hiéroglyphique", in Görg, M.; Pusch, E. (eds.), Festschrift Elmar Edel, (ÄAT 1, Studien zur Geschichte, Kultur und Religion Ägyptens und des Alten Testaments), Bamberg: 446-455.

Desroches-Noblecourt, C.

1953 "Un "lac de turquoise", godets à onguents et destinées d'outre-tombe dans l'Égypte ancienne", Fondation Eugène Piot, monuments et mémoires publiés par l'Académie d'Inscriptions et Belles Lettres 47, Paris: 1-34.

(COORD.) 1976 Galeries Nationales du Grand Palais, Ramsès le Grand (catalogue d'exposition), Paris.

1991 "Les Trois Saisons du dieu et le débarcadère du ressuscité", MDAIK 47 (Festschrift für Werner Kaiser): 67-80.

DÉVERIA, TH.

1872 Le Papyrus de Nebqued, Paris.

1881 Catalogue des manuscrits égyptiens écrits sur papyrus, toile, tablettes et ostraca en caractères hiéroglyphiques, hiératiques,

[ 100 ] démotiques, grecs, coptes, arabes et latins qui sont conservés au musée égyptien du Louvre, Paris.

Diego Espinel, A.

2006 Etnicidady Territorio en el Egipto del Reino Antiguo, (Aula Asgyptiaca Studia 6), Bellaterra.

Egeberts, A.

1995 In quest of Meaning. A Study of the An- cient Egyptian Rites of Consecrating the Meret-Chests and Driving the Calves, 2 vols, Leiden.

FAULKNER, R.O.

19943 [1973-1978] The Ancient Egyptian Coffin Texts, vols. I-III, London.

FAULKNER, R.O.; GoELET, O. JR.

1994 The Egyptian Book of the Dead. The Book of Going Forth by Day. The first authentic presentation of the Complete Papyrus of Ani, Cairo.

FrankFort, H.

1933 The Cenotaph of Sety at Abydos, II vols, (EES 39), London.

GARDiner, A.H.

1938 "The Mansion of Life and the Master of the King's Largess", JEA 24: 83-91, pl. V-VI.

1957 "Hymns to Sobek in a Ramesseum Papyrus", $R d E ́$ 11: 43-56.

Gasse, A.

1993 Les Papyrus hiératiques et hiéroglyphiques du Museo Gregoriano Egizio, Monumenti, Musei e Gallerie Pontificie, Museo Gregoriano Egizio, (Aegyptiaca Gregoriana I), Città del Vaticano.

2001 Le Livre des Morts de Pacherientaihet au Museo Gregoriano Egizio, Monumenti, Musei e Gallerie Pontificie, Museo Gregoriano Egizio, (Aegyptiaca Gregoriana IV), Città del Vaticano.

GAUTHIER, H.

1975 [1925-1931] Dictionnaire des Noms Géographiques contenus dans les textes hiéroglyphiques, I-VII vols, Osnäbruck.

Geisen, C.

2004 Die Totentexte des verschollenen Sarges der Königin Mentuhotep aus der 13. Dynastie. Ein Textzeuge aus der 
übergangszeit von den Sargtexten zum Totenbuch, (SAT 8), Wiesbaden.

Gesellensetter, J. S.

2002 Das Sechet-Iaru: Untersuchungen zur Vignette des Kapitels 110 im Ägyptischen Totenbuch, Würzburg.

GESSLER-LÖHR, B.

1983 Die heiligen Seen ägyptischer Tempel, ein Beitrag zur Deutung sakraler Baukunst im alten ägypten, (Ḧ̈B 21), Hildesheim.

Goebs, K.

1995 "Untersuchungen zür Funktion und Symbolgehalt des nms", Z̈̈S 122: 154-181.

GODRON, G.

1990 Études sur l'Horus Den et quelques problèmes de l'Égypte archaïque, (Cahiers d'Orientalisme XIX), Gèneve.

GomaÀ, F.

1977 s.u. "Herakleopolis Magna", LÄ II, 1124-1127.

1986 Die Besiedlung Ägyptens während des Mittleren Reichs, I. Oberägypten und das Fayyum, (TAVO Reihe B 66/1), Wiesbaden.

GRAPOW, H.

1915-1917 Urkunden V, Religiöse Urkunden, Leipzig.

GRIFFITHS, J.G.

1980 The Origins of Osiris and his cult, Leiden.

Guilmant, M.P.

1907 Le Tombeau de Ramsés IX (MIFAO 15), Le Caire.

GÜlden, S.A.; MunRo, I.

1998 Bibliographie zum Altägyptischen Totenbuch, (SAT 1), Harrassowitz, Wiesbaden.
HASSAN, S.

1928 Hymnes religieux du Moyen Empire, IFAO, Le Caire.

Hawass, Z.

2006 The Royal Tombs of Egypt. The Art of Thebes Revealed, London.

Heerma Van Voss, M.S.G.H.

1963 De oudste versie van Dodenboek 17 a, Coffin Texts Spreuk 335 a, Leiden.

Hofmann, E. ET AL.

1995 Das Grab des Neferrenpet Gen. Kenro (TT 178), Mainz am Rhein.

HoRnUNG, E.

1990 [1979] Das Totenbuch der Ägypter: Eingeleitet, übersetzt und erläutert, Münich.

JONES, D.

2000 An Index of Ancient Egyptian Titles, Epithets and Phrases of the Old Kingdom, 2 vols, (BAR International Series 866, I y II), Oxford.

KÁKOSY, L. ET AL.

2004 The Mortuary Monument of Djehutymes (TT 32), (Studia Aegyptiaca Series Maior I), Budapest.

KaPLONY-HeCKel, U.

1986 Ägyptische Handschriften Teil 3, (Verzeichnis der Orientalischen Handschriften in Deutschland XIX. 3), Stuttgart.

KeEs, $\mathrm{H}$.

1930 "Göttinger Totenbuchstudien. Ein Mythus vom königtum des Osiris in Herakleopolis aus dem Totenbuch Kap. 175”, Z̈̈S 30: 65-83.

KuFFER, A.

2006 "Sous la protection de Nout, déesse du ciel: le trousseau funéraire du prêtre 
Nes-shou au Musée d'Yverdon et région", Archäologie Scheiwz/Archéologie Suisse 29: 2-13, pl. 11-12.

LAPP, G.

1993 Typologie der Särge und Sargkammern von der 6. bis 13 Dynastie, (SAGA 7), Orientverlag, Heidelberg.

2004 The Papyrus of Nebseni (BM EA 9900), Catalogue of the Books of the Dead in the British Museum, vol. III, London.

2006 Totenbuch Spruch 17, (Totenbuchtexte Synoptische Textausgabe nach Quellen des Neuen Reiches), Basel.

Leblanc, C.; Nelson, M.

1997 "Répertoire onomastique des propriétaires des tombes de la Troisième Période Intermédiare du Ramesseum [I]", Memnonia 8: 61-91.

Leemans, C.

1841-1842 Aegyptische Lijk-Papyrus in Hieroglyphisch Schrift, vit het Nederlandse Museum van Oudhesden te Leyden, Leiden.

1867-1876 Papyrus égyptien funéraire hiértique (T16), Leiden.

1882 Aegyptische Monument en van het Nederlansdische Museum von Oudheden, Leiden.

LEFÉBURE, E.

1889 Les hypogées royaux de Thebes $2^{\text {ème }}$ édition: Notices des hypogées, (MIFAO 3. 1), Le Caire.

[ 102 ] LEFEBVRE, G.

2003 [1982] Mitos y cuentos Egipcios de la época Faraónica, Madrid.

LEPSIUS, R.

1969 [1842] Das Todtenbuch der Ägypter: Nach dem Hieroglyphischen Papyrus in Turin, C. Wigand, Leipzig.

LiMME, L.

1983 “Trois « Livres des Morts » illustrés des Musées Royaux d'art et d'histoire à Bruxelles", in De Meulenaere, H.; Limme, L. (eds.): Artibus Aegypti Studia in Honorem B. V. Bothmer, A Collegis Amici Discipulis Conscripta, Bruxelles: 81-99.

LISE, G.

1979 Museo Archeologico Raccolta Egizia, Mailand.

LOEBENSTEIN, H.

$1972^{3}$ Die Papyrussamlung der österreichischen Nationalbibliothek, (BiblosSchriften 67), Wien.

LUCARELLI, R.

2006 The Book of the Dead of Gatsesehn, Ancient Egyptian Funerary Religion in the $10^{\text {th }}$ Century B.C., (EU XXI), Leiden.

LÜSCHER, B.

2000 Das Totenbuch pBerlin P. 10477 aus Achmin (mit Photographien des verwandten pHildesheim 5248), (Ḧ̈T 6), Wiesbaden.

MeEKs, D.

1980-1982 Année Lexicographique. Égypte Ancienne I (1977), II (1978), III (1979), Paris.

MiLde, $\mathrm{H}$.

1991 The Vignettes in the Book of the Dead of Neferrenpet, (EU 7), Leiden.

MoKhtar, G.M.

1983 Ihnâsya El-Medina (Herakleopolis Magna). Its Importance and its Role in Pharaonic History, (BdÉ 40), Le Caire.

Montet, P.

1931 "Contribution à l'étude des Mastabas de l'Ancien Empire", Kêmi 4: 161-189.

MOSHER, M. JR.

1990 The Ancient Egyptian Book of the Dead 
in the Late Period: A Study of Revisions Evident in Evolving Vignettes, and the Possible Chronological or Geographical Implications for Differing Versions of Vignettes, Dissertation, University of California, Berkeley.

1992 "Theban and Memphite Book of the Dead Traditions in the Late Period", JARCE 29: 143-172.

2001 Catalogue of the Books of the Dead in the British Museum, Volume II: The Papyrus of Hor, London.

MunRo, I.

1988 Untersuchungen zu den Totenbuch-Papyri der 18. Dynastie. Kriterien ihrer Datierung, D 7, "Göttinger Philosophische Dissertation", (Studies on the Book of the Dead of the 18 th Dynasty), London, New York.

1994 Die Totenbuch-Hahdscriften der 18. Dynastie im Ägyptischen Museum Cairo, (Ä̈ 54), Wiesbaden.

1997 Das Totenbuch des Nacht-Amun, (Ḧ̈T 4), Wiesbaden.

2001a Spruchvorkommen auf Totenbuch-Textzeugen der Dritten Zwischenheit, (SÄT 5), Wiesbaden.

2001b Das Totenbuch des Pa-en-nesti-taui (pLondon BM 10064) aus der Regierungszeit des Amenemope (Ḧ̈T 7), Wiesbaden.

Naville, E.

1886 Das aegyptische Totenbuch der XVIII. bis XX. Dynastie: Aus verschiedenen Urkunden zusammengestellt und herausgegeben, 2 Bande., Berlin. (Abridged in catalogue as " $\mathrm{Tb}$ ")

1894 Ahnas el Medineh (Heracleopolis Magna): with chapters on Mendes, the Nome of Thot, and Leontopolis, (EEF XI Memoir), London.

NÈRET, G.

2002 [1995] Description de l'Égypte. Publiée par les ordres de Napoléon Bonaparte. Edition complète, Köln.

NEWBERry, P.E.

1899 The Amherst papyri, being an account of the Egyptian papyri in the collection of the Right Hon. Lord Amherst of Hackney, F.S.A., at Didlington Hall, Norfolk, London.

NiBLEY, H.

2005²[1975] The Message of the Joseph Smith Papyri. An Egyptian Endowment. (The Collect works of Hugh Nibley 16), Utah.

Niwinski, A.

$198821^{\text {st }}$ Dynasty Coffins form Thebes. Chronological and Typological Studies, Mainz am Rhein.

1989 Studies on the illustrated Theban Funerary Papyri of the 11 th and 10 th Century B.C., (OBO 86), Freiburg, Göttinger.

Ockinga, B.G.; AL-MasRi, Y.

1988-1990 Two Ramesside Tombs at El Mashayikh. Part 1 The Tomb of Anhurmose - the outer Room; Part 2. The tomb of Anhurmose - the Inner Room and the Tomb of Imiseba, Sydney.

OGdON, J.R.

1985 "Studies in Ancient Egyptian Magical Thought, II. The "Eye of Re"", $D E$ 2: 37-44.

OsING, J.

1982 "Die Gräber des Pedubastis", in Osing, J. (ed.): Denkmäler der Oase Dachla. Aus dem Nachlass von Ahmed Fakry, (AV 28), Mainz: 71-81.

PADRÓ, J.

1999 Études historico-archéologiques sur Heracleopolis Magna, (Nova Studia Aegyptiaca I), Barcelona. 
PARKINSON, R.B.

1991 The Tale of the Eloquent Peaseant, Oxford.

PARKINSON, R.; Quirke S.

1992 "The Coffin of Prince Herunefer and the Early History of the Book of the Dead", in Lloyd, A.B. (ed.): Studies in Pharaonic Religion and Society (Fs Griffiths), (EES $O P$ 8): 37-51, Tab II, 1-IV.

Pérez Die, M.C.

2001 "Fouilles à Ehnasya el Medina (Hérakléopolis Magna), Égypte. Résultats récentes (campagne année 2000)", BSFE 150: 6-25.

2005a "La nécropole de la Première Période Intermédiaire-début du Moyen Empire à Héracleopolis Magna. Nouvelles découvertes et résultats récents (campagne 2001)", in Pantalacci, L. (ed.): Des Néferkare aux Montouhotep, travaux archéologiques en cours sur la fin de IVe dynastie et la Première Période Intermédiaire; actes du Colloque CNRS, tenu le 5 - 7 juillet 2001, (TMO 40), Lyon: 239-254.

2005 b "Excavaciones en Ehnasya el-Medina (Heracleópolis Magna). Campañas de 2000 y 2001", in Cervello Autuori, J., et al. (ed.): Actas del Segundo Congreso Ibérico de Egiptología, Bellaterra, 12-15 de Marzo de 2001, (AAES 5), Bellaterra: 253-259.

Pérez Die, M.C.; Vernus, P.

1992 Excavaciones en Ehnasya el Medina (Heracleópolis Magna) I.- Introducción e Inscripciones, (Informes Arqueológicos/Egipto 1), Madrid.

Petrie, W.M.F.

1900-1901 The Royal Tombs of the first Dynasty, II vols., London.

Piankoff, A.; Rambova, N.

1957 Mythological Papyri. Texts and plates,
(Bollingen Series XL-3), New York.

1954 The Tomb of Ramesses VI, 2 vols, (Bollingen Series XL), New York.

Piotrovsly, M.

1974 Egyptian Antiquities in the Hermitage, Leningrad.

Posener-Krieger, P.

1976 Les archives du temple funéraire de Néferirkarê-Kakaï (Les papyrus d'Abousir), (BdÉ 65), Le Caire.

Quirke, S.

1993 Owners of Funerary Papyri in the British Library, (BMOP 92), London.

1999a "The last Books of the Dead?", in Davies, W.V. (ed.): Studies in Egyptian Antiquities. A tribute to T.G.H. James, (BMOP 123): 83-98.

1999 b "Two Books of the Dead of a Ptolemaic Psamtek", OMRO 79: 37-66

REEVES, N.; WiLKINSON, R.H.

1999 [1996] Todo sobre el Valle de los Reyes. Tumbas y tesoros de los principales faraones de Egipto, Barcelona.

Rosati, G.

1991 Libro dei Morti: i papiri torinesi de Tachered e Isiemachbit (Testi del Vicino Oriente Antico 1, Letteratura egiziana classica 2), Brescia.

RÖSSLER-KÖHLER, U.

1979 Kapitel 17 des ägyptischen Totenbuches, (GOF IV. 10), Wiesbaden.

1999 Zur Tradierungsgeschichte des Totenbuches zwischen der 17. und 22. Dynastie (Tb 17), (SAT 3), Wiesbaden.

Rотн, A.M.

1991 "The Distribution of the Old Kingdom title hnty-s" in Schoske, S. (ed.): Akten des vierten internationalen ägyptologen Kongresses, München 1985, (SAK4): 177-186. 
SAleh, M.

1984 Das Totenbuch in den Thebanischen Beamtengräbern des Neuen Reiches: Texte und Vignetten, (AVDAIK, 46), Mainz.

SATZINGER, $\mathrm{H}$.

1994 Das Kunsthistorische Museum in Wien. Die orientalische Sammlung, (Zaberns Bildbände zür Archäologie 14), Mainz.

SCHÄFER, $\mathrm{H}$.

1902 Ein Bruchstück altägyptischer Annalen, Berlin.

SCHENKEL, W.

1975 "Zur Redaktions- und Überlieferungsgeschichte des Spruchs 335 A der Sargtexte", in Westendorf, W. (ed.): Göttinger Totenbuchstudien: Beiträge zum 17. Kapitel, (GOF IV. 3), Wiesbaden: 37-81.

Sснотт, E.

1992 Die Ägyptischen Sünden. Kapitel 125 und Kapitel 30 des ägyptischen Totenbuches übersetzt und kommentiert, Göttingen.

SeEber, C.

1976 Untersuchungen zur Darstellung des Totengerichts im Alten Ägypten, (MÄS 35), Berlin, Münich.

Shalomi-Hen, R.

2000 Classifying the Divine. Determinatives and Categorisation in CT 335 and $B D$ 17, Wiesbaden.

SмITH, W. ST.

1960 Ancient Egypt as represented in the Museum of Fine Arts, Boston.

Stadelman, R.

1981 "Die hntyw-š, der Königsbezirk $\check{s} n$ pr-e und die Namen der Grabanlagen der Frühzeit", Bulletin du centenaire, suppl. BIFAO 81: 153-164.
TAYLOR, J.H.

2001 Death and the Afterlife in Ancient Egypt, London.

Thausing, G.; Goedicke, H.

1971 Nofretari: Eine Dokumentation der Wandgemälde ihres Grabes: Einleitung und Kommentar, Graz.

TiRADRITTI, F. (ED.)

1999 Il Cammino di Harwa. L'uomo di fronte al mistero: L'Egitto, Milano.

VAlloglia, $\mathrm{M}$.

2000 "Les manuscrits hiératiques et hiéroglyphiques de la Bibliotheca Bodmeriana", in Chappaz, J.L.; Vuilleumier, S., (eds.): Sortir au jour. Art égyptien de la Fondation Martin Bodmer, (CSÉG 7), Genève.

VAN Es, M.H.

1982 "Das Totenbuch des Ptahmose", Z̈̈S 109: 97-121.

VANDERSLEyen, C

1991 "Le Sens de Ouadj-Our ( $W 3 d-W r)$ ", en Schoske, S. (ed.): Akten des vierten internationalen ägyptologen Kongresses, München 1985, (SAK 4): 345-352.

VERCOUTTER, J.

1950 "Les statues du général Hor, gouverneur d'Hérakléopolis, de Busiris et d'Héliopolis (Louvre A 88, Alexandrie, s.n.)", BIFAO 49: 85-114.

Verhoeven, U.

1993 Das saitische Totenbuch der Iahtesnacht, P. Colon. Aeg 10207, 3 Bde., (PTA 41/ 1-3), Bonn.

1998 "Internationales Totenbuch-Puzzle, $R d E$ 49: 211-237.

Vernus, P.

1967 “Une localité de la Région d'Héracléopolis", $R d E$ 19: 166-169. 
VON FALCK, F.

2006 Das Totenbuch der Qeqa aus der Ptolemäerzeit (pBerlin P. 3003), (Ḧ̈T 8), Wiesbaden.

Wainwright, A.

1934 "Some Aspects of Amun", JEA 20: 139-153.

Walle VAn de, B.

1985 'Le sens de la Vue et la vertu du regard dans la mentalité égyptienne", in Geus, F. ; Thill, F. (eds.): Mélanges offerts a Jean Vercoutter, Paris: 365-374.

WAZIER, A.W.

1998 "The Title imy-r sš in Its Different forms", in Proceedings of the eigtht International Congress of Egyptologists, (OLA 82), Cairo. Vol 3: 422-429.

WeILL, R.

1936-1937 "Bélier du Fayoum et 21e nome de la Haute-Égypte", BIFAO 36: 129-143.

Wiese, A.; Brodbeck, A.

2004 Toutankhamon. L'or de l'Au-Delà. Trésors funéraires de la Vallée des Rois, Cybelle

WiLKInSON, R.H.

1992 Reading Egyptian Art. A Hieroglyph Guide to Ancient Egyptian Painting and Sculpture, London.
WiLKInsOn, T.A.H.

2000 Royal Annals of Ancient Egypt. The Palermo Stone and its Associated Fragments, London.

WiLLEMS, H.

1988 Chests of Life, A Study of the Typology and Conceptual Development of Middle Kingdom Standard Class Coffins, (MVEOL 25), Leiden.

1996 The Coffin of Heqata (Cairo JdE 36418): A case study of Egyptian Funerary Culture of the Early Middle Kingdom, (OLA 70), Leuven.

1997 "The Embalmer embalmed, remarks on the meaning of the decoration on some Middle Kingdom Coffins", in Van Dijk, J. (ed.): Essays on Ancient Egypt in honour of Herman Te Velde, (Egyptological Memoirs I), Groningen: 343-372.

ZiBELIUS, K.

1978 Ägyptischen Siedlung nach Texten des Alten Reiches, (TAVO Reihe B 9), Wiesbaden

ZIEGLER, CH.

1979 "Deux étoffes funéraires égyptennes", Révue du Louvre et des Musées de France 29: 251-257, pls. 5-8.

ZIVIE, A.P.

1979 La Tombe de Pached à Deir El-Medineh [N $\left.{ }^{\circ} 3\right],(M I F A O$ 94), Le Caire. 


\section{Juan Antonio Belmonte}

Instituto de Astrofísica de Canarias

Vía Láctea $\mathrm{S} / \mathrm{N}$

38200 La Laguna, Tenerife - Islas Canarias

España

$$
\text { jba@iac.es }
$$

\section{Marcelo Campagno}

Instituto Multidisciplinario de Historia y Ciencias Humanas

Departamento de Egiptología

Saavedra $15,5^{\circ}$ piso

C1083ACA Buenos Aires

Argentina

mcampagno@fibertel.com.ar

\section{Lucía Elena Díaz-Iglesias Llanos}

Dpto. de Prehistoria, Antropología e Historia Antigua

Facultad de Geografía e Historia - Campus de Guajara

38071 Universidad de La Laguna

Tenerife - Islas Canarias

España

luch68@hotmail.com

\section{Magdi Fekri}

Faculty of Tourism

Minufiya University

El-Sadat City

Egypt

per-ankh@hotmail.com

\section{Cristina Pino Fernández}

cristinapino@telefonica.net 


\section{Mosalam Shaltout}

Helwan Observatory

Helwan, Cairo

Egypt

mosalamshaltout@hotmail.com

\section{Eric P. Uphill}

Institute of Archaeology

University of London

31-34 Gordon Square

London WC1H OPY

United Kingdom

\section{Marie-Paule Vanlathem}

Association Égyptologique Reine Élisabeth Musées Royaux d'Art et d'Histoire

Parc du Cinquantenaire 10

B-1000 Bruxelles

Belgique

mariepaule.vanlathem@belgacom.net 


\section{Trabajos de Egiptología}

\section{Papers on Ancient Egypt}

P

Número 4 2005 


\title{
Consejo Editorial
}

\author{
Miguel Á. Molinero Polo \\ Universidad de La Laguna \\ Antonio Pérez Largacha \\ Universidad de Castilla-La Mancha \\ José-R. Pérez-Accino \\ Birkbeck, Universidad de Londres \\ Covadonga Sevilla Cueva \\ Universidad Autónoma de Madrid
}

\section{Comité Científico}

Josep Cervelló i Autuori

Aula Aegyptiaca, Barcelona

Ma José López Grande

Universidad Autónoma de Madrid

Josep Padró i Parcerisa

Universitat de Barcelona

$\mathrm{M}^{\mathrm{a}}$ Carmen Pérez Die

Museo Arqueológico Nacional, Madrid

Ester Pons Mellado

Museo Arqueológico Nacional, Madrid

José M. Serrano Delgado

Universidad de Sevilla

\section{Colaboradores Editoriales}

Linda Steynor

English editorial assistant

Hervé Mouriacoux

Assistant editoriale pour langue française 
Juan Antonio Belmonte, Mosalam Shaltout, Magdi Fekri

Astronomy and landscape in Ancient Egypt:

Challenging the enigma of the minor step pyramids

\section{Marcelo Campagno}

Two observations on the tales of The contendings of Horus and Seth and Truth and Falsehood

\section{Lucía Elena Díaz-Iglesias Llanos}

Commentary on Heracleopolis Magna from the theological perspective (I):

The image of the local lakes in the vignette of chapter 17 of the Book of the Dead

Cristina Pino Fernández

Prince Ahmose Sapair again

Eric P. Uphill

Irrigation basins and cultivated land under the Twelfth Dynasty

\section{Marie-Paule Vanlathem}

Cléopâtre dans le miroir de la peinture du XIXe siècle 
Trabajos de Egiptología está producida por Isfet. Egiptología e Historia.

c/ Blanco $1,2^{\circ}$

38400 Puerto de la Cruz

Tenerife - Islas Canarias

España

Maquetación: Ignacio Cases

(C) Autores de los artículos aparecidos

y Consejo Editorial de Trabajos de Egiptología - Papers on ancient Egypt

Depósito legal:

ISSN 1695-4750

Impresión: 